\title{
A TÚZOK (Otis tarda L.) ÉLŐHELYHASZNÁLATA ÉS ÉLŐHELYVÁLASZTÁSA MAGYARORSZÁGON
}

\author{
Faragó Sándor \& Kalmár Sándor \\ Nyugat-magyarországi Egyetem, Vadgazdálkodási és Gerinces Állattani Intézet \\ University of West-Hungary, Institute of Wildlife Management and Vertebrate Zoology \\ H-9400 Sopron, Ady Endre u. 5., Hungary
}

\begin{abstract}
FARAGÓ, S. \& KalmáR, S.: HABITAT USE AND habitat SEleCtion OF GREAT BuSTARD (Otis tarda L. 1758) IN HUNGARY. Hungarian Small Game Bulletin 12: 33-104. http://dx.doi.org/10.17243/mavk.2014.033

Between 2005 and 2008 the LIFE Great Bustard Protection Program was created and it focused on 9 highly important Bustard regions in Hungary. Within the regions, habitat mapping was carried out at certain monitoring areas (25-112 $\mathrm{km}^{2}$ each, $494 \mathrm{~km}^{2}$ together) and the recording of time-space patterns of Bustard occurrence made it possible to clarify the habitat use and preference of the species in Hungary. During springtime, low-growing cultivated plants (grassland, winter cereals, alfalfa and oil seed rape), fallow, set-aside, ploughed fields are preferred. During summertime, their selected habitats are stubble-field, fallow, set-aside, ploughed and harrowed fields. During wintertime, winter cereals and grasslands may not be favourable because of the snow-cover. Everywhere and at all times rape is preferred.

The defined regulations on a preliminary and experimental basis of the habitat structure of areas suitable for Great Bustards in the regions fulfilled the expectations. Where they were put into effect, landoccupation and the use/selection of habitats was successful. Where the introduction and maintenance of the key habitat types (e.g. rape, winter cereals) did not happen, the Bustards left the areas. The necessity of habitat diversity was justified, since tolerant changing habitat patterns in time and space are more attractive, than the monotony of the original grassland for example.
\end{abstract}

KULCSSZAVAK: túzok, Otis tarda, élőhely használat, élőhely választás, Magyarország KEY WORDS: Great Bustard, Otis tarda, habitat use, habitat selection, Hungary

\section{BEVEZETÉS}

A magyar túzokállomány még olyan nagyságú, populációinak belső szerkezeti paraméterei (sürüség, ivararány, korösszetétel) még olyanok, hogy esély van a faj megőrzésére. A KISKUNSÁGI NEMZETI PARK gesztorságával, a legszélesebb területi és szakmai alapon, megszervezett és az EU által finanszírozott LIFE-Nature Program elnyert forrásainak hadrendbe állításával 2005-2008 között olyan természetvédelmi kutatási és gyakorlati Project valósult meg, amely eredményességével és szerzett ismeretanyagával a legsikeresebb természetvédelmi akciók közé sorolandó.

A LIFE Túzokvédelmi Program müködésének 4 éve során, az ország 9 kiemelten fontos túzok-élöhelyére összpontosítva végezte munkáját, amely programterületek lefedték a faj legfontosabb hazai előfordulási régióit. A programterületek összes kiterjedése $25-730 \mathrm{~km}^{2}$ között változott, összesen $2413 \mathrm{~km}^{2}$ volt (I. melléklet). Valamennyi területet lefedte a magyar NATURA 2000 hálózat. Az egyes programterületeken belül kijelölésre kerültek ú.n. monitoring területek, amelyeken kiterjedt (túzokállomány megfigyelése, fészkelés, predátor fajok előfordulás-dinamikája és szaporodása, élőhely-térképezés, tér-idő mintázat, veszélyeztető 
tényezők) vizsgálatok folytak. A monitoring területek nagysága $25-112 \mathrm{~km}^{2}$ között változott, összesen $494 \mathrm{~km}^{2}$-t tett ki (FARAGÓ \& KALMÁR, 2006; 2007; KALMÁR \& FARAGÓ, 2008)

Jelen munka a monitorozott tényezők közül a túzokállomány élőhelyeinek kínálatát, a faj élöhelyhasználatát és élőhelyválasztását mutatja be térben és időben. Bemutatja e paraméterekben bekövetkezett változásokat és elemzi azokat olyan jellemzőkkét, amelyeknek ismerete a Project megvalósulása szempontjából az egyik legfontosabb információ volt.

Közismert, hogy a mezei élettérben élő állatfajok állományváltozásainak legfontosabb kérdése az élőhelyek védelme, az élőhelyek fejlesztése (FARAGÓ, 1997a). Különösen fontos ez olyan faj esetében, amely az elmúlt évszázadokban élőhelyváltáson ment keresztül. A sztyeppei, erdős sztyeppei élettérből a mezőgazdasági területekre átköltöző túzok számára ez az élőhelyváltás csak előnyökkel járt, hiszen az extenzív mezőgazdálkodás időszakában az új élőhelyek areájának növekedését (pl. irtásterületek, lecsapolt mocsarak stb. elfoglalása), illetőleg állományainak, szaporulatának eredményesebb fenntartását jelentették (FARAGÓ, 1990a).

A mezőgazdaság intenzívvé válásával ez a helyzet gyökeresen megváltozott, a túzok az intenzíven kezelt mezei környezetben ökológiai csapdába került. Az élőhelyválasztása ökológiai ismérvek alapján történik, mindeközben azonban fellépnek olyan technológai munkafázisok, amelyek pusztuláshoz, fészekvesztéshez, mindezek által állománycsökkenéshez vezetnek (FARAGÓ, 1989).

Az élőhelyválasztás ismerete minden védelmi területen elengedhetetlen, éppen ezért ennek felmérése a LIFE Project kiemelt kutatási feladata volt.

\section{ANYAG ÉS MÓDSZER}

\section{1. Élőhely használat és élőhelyválasztás}

Az egyes programterületeken belül kijelölésre kerültek olyan mintaterületek, amelyek élőhelyszerkezetük alapján reprezentálják az egész programterületet. A Mosoni-sík, illetve a Kis-sárrét esetében az egész programterületet mintaterületként értékeltük. A kilenc kijelölt mintaterületen évi három alkalommal, tavasszal, nyáron, télen történt a teljes terület élőhelystruktúrájának felvételezése, amelyek alapján képet kaptunk az egyes élőhely-típusok (ezen belül is elsősorban a mezőgazdasági kultúrák) százalékos megoszlásáról, amely értékeket a túzok számára elérhető élőhely kínálatnak tekintünk. Ezt összevetve az adott időszakban a mintaterületen észlelt túzokok százalékban kifejezett élőhely-használatával, képet kaphatunk a faj élőhely-preferenciájáról, amelyet az ú.n. IVLEV-index (IVLEV, 1961) alábbi képlete alapján számítunk:

$$
\text { Iv }=\frac{\text { élőhelyhasználat }- \text { élőhelykínálat }}{\text { élőhelyhasználat }+ \text { élőhelykínálat }}
$$

A grafikusan is ábrázolt IVLEV-indexek jól szemléltetik a szezonálisan preferált élőhelytípusokat, amely ismeretek fontos kritériumai a célirányos agrár-környezetgazdálkodási programoknak, ezen keresztül pedig a hatékony túzokvédelemnek.

Ilyen jellegü vizsgálatok folytak például túzokkal kapcsolatosan Spanyolországban (AlONSO \& ALONSO, 1990), fogollyal kapcsolatosan Magyarországon (FARAGÓ, 1998). 
A területek fészkelési szempontból történő minősítésére megadtuk az egyes területek esetében a ,jósági" értékeket. A minősítés mindig az élőhely-térképezés alá vont monitoring területre vonatkozott.

Egy ötfokú skálán értékelhetjük, hogy az egyes termesztett növények termesztéstechnológiái mekkora veszélyforrást jelentenek a madárfajok szaporodási időszakában (FARAGÓ, 1992), illetve, hogy általában a különböző élőhelytípusok mennyire kedvezőek, vagy kedvezőtlenek a földön fészkelö madarak számára. A fokozatok a következők:

- 5: nagyon kedvező - a fészkelési időszakban nem, vagy alig folyik benne munka,

- 4: kedvező - munka ritkán folyik benne, de a betakarítás során a sarjúfészkek megsemmisülnek,

- 3: közepes - csak a szaporodási időszak második felében (sarjúfészkelés) mentes a munkáktól,

- 2: kedvezőtlen - a késő tavaszi vetés és a kései ápolások miatt első fészkelés lehetetlen benne, sarjúfészkelés lehetséges,

- 1: igen kedvezőtlen - a kaszálások (betakarítás) miatt rendszeresen mind az első, mind a sarjúfészkek megsemmisülnek.

1. táblázat: Mezei élőhelytípusok, mint fészkelőhelyek minősítése (FARAGó, 1993 után módosítva) - (z: zölden, folyamatosan betakarítva)

Table 1: Qualification of agrar habitats as nesting sites (modified after FARAGÓ, 1993) - (g: green fodder, harvested permanently)

\begin{tabular}{|c|c|c|c|c|}
\hline $\begin{array}{c}5 \\
(\times 1.00)\end{array}$ & $\begin{array}{c}\mathbf{4} \\
(\times 0.75)\end{array}$ & $\begin{array}{c}3 \\
(\times 0.50)\end{array}$ & $\begin{array}{c}2 \\
(\times 0.25)\end{array}$ & $\begin{array}{c}1 \\
(\times 0.00)\end{array}$ \\
\hline $\begin{array}{c}\text { természetes gyepek } \\
\text { natural grassland }\end{array}$ & $\begin{array}{l}\text { repce } \\
\text { rape }\end{array}$ & $\begin{array}{c}\text { új vetésü lucerna } \\
\text { alfalfa new plantation }\end{array}$ & $\begin{array}{l}\text { cukorrépa } \\
\text { sugar beet }\end{array}$ & $\begin{array}{l}\text { kaszált gyep (vetett) } \\
\text { mown grass (planted) }\end{array}$ \\
\hline $\begin{array}{l}\text { parlag } \\
\text { fallow }\end{array}$ & $\begin{array}{c}\text { borsó } \\
\text { pea }\end{array}$ & $\begin{array}{l}\text { tavaszi árpa } \\
\text { spring barley }\end{array}$ & $\begin{array}{c}\text { burgonya } \\
\text { potato }\end{array}$ & $\begin{array}{c}\text { lucerna } \\
\text { alfalfa }\end{array}$ \\
\hline $\begin{array}{c}\text { ugar } \\
\text { set-aside }\end{array}$ & $\begin{array}{l}\text { egyéb pillangósok } \\
\text { other papilionaceae }\end{array}$ & $\begin{array}{l}\text { napraforgó } \\
\text { sunflower }\end{array}$ & & $\begin{array}{l}\text { füves here }(\mathrm{z}) \\
\text { grass \& clovers }(\mathrm{g})\end{array}$ \\
\hline $\begin{array}{c}\text { őszi búza } \\
\text { winter wheat }\end{array}$ & & $\begin{array}{l}\text { silókukorica } \\
\text { silo maize }\end{array}$ & & $\begin{array}{c}\text { hibrid kukorica } \\
\text { hybrid maize }\end{array}$ \\
\hline $\begin{array}{c}\text { őszi árpa } \\
\text { winter barley }\end{array}$ & & $\begin{array}{l}\text { árukukorica } \\
\text { crop maize }\end{array}$ & & $\begin{array}{l}\text { silókukorica }(\mathrm{z}) \\
\text { silo maize }(\mathrm{g})\end{array}$ \\
\hline $\begin{array}{l}\text { rozs, zab } \\
\text { rye, oat }\end{array}$ & & & & $\begin{array}{c}\text { rozs }(\mathrm{z}), \text { őszi árpa }(\mathrm{z}) \\
\text { rye }(\mathrm{g}), \text { winter barley }(\mathrm{g})\end{array}$ \\
\hline \multirow[t]{2}{*}{$\begin{array}{c}\text { vadföld } \\
\text { game crop field }\end{array}$} & & & & $\begin{array}{c}\text { cikória, mák, zöldség } \\
\text { chicory, poppy, vegetable }\end{array}$ \\
\hline & & & & $\begin{array}{c}\text { öntözött terület } \\
\text { irrigated area }\end{array}$ \\
\hline
\end{tabular}

A project-területeken előforduló legjellegzetesebb termesztett növényeket, illetve az egyéb élőhelytípusokat minősítési-értékük szerint a 1. táblázatban foglaltuk össze. A 9 project terület esetében adott élőhely (pl. gyep) besorolási értéke eltérő lehet, függően az alkalmazott technológiától, védelemtől, gazdálkodótól (pl. ÉTT kezelés), így előfordult, hogy egy-egy terület esetében területre szabott minősítési értékeket használtunk a számításokhoz. Ezeket a kivételeket az adott fejezetben feltüntettük.

Mindezek alapján egyszerüen értékelhettük az egyes területek, túzokpopulációk élettereinek veszélyeztetettségét. Annál kedvezőbb egy terület, minél kisebb a 3., 2., 1. kategóriájú területek részaránya. E módszerrel minősített területeket könnyen össze is lehet hasonlítani. Az értékeléskor megadtuk a kategóriákhoz tartozó földterületek \%-os arányát, majd ezeket beszoroztuk a kategóriák szorzószámával: 


$\begin{array}{ll}\text { 5. kategória } & : 1,00 \\ \text { 4. kategória } & : 0,75 \\ \text { 3. kategória } & : 0,50 \\ \text { 2. kategória } & : 0,25 \\ \text { 1. kategória: } & : 0,00\end{array}$

Ezt követően megkaptuk a redukált területarányt, amely azt fejezi ki, hogy az adott érték hány \%-a a potenciálisnak/maximálisnak. 100\%-nak tehát azt az állapotot tekintjük, mintha egy területen csak 5. kategóriájú élöhelyek lennének.

Példaként egy hagyományos gazdálkodást folytató mezőgazdasági nagyüzem területe (LAJTA Project) jóval kedvezőtlenebb (56,16\%), mint egy olyan terület (MOSON Project), ahol a túzok és az apróvad számára élőhelyfejlesztés történt (78,63\%) (2. táblázat). A MOSON Project élőhelyfejlesztései a táblák egész területére kiterjedtek, szemben a LAJTA Projecttel, ahol mindezek csak táblaszegélyekben történtek (FARAGÓ, 1993).

2. táblázat: A LAJTA Project és a MOSON Project területének minősítése fészkelés szempontjából (FARAGó, 1993)

Table 2: Qualification of area of LAJTA Project and MOSON Project nesting terms

\begin{tabular}{|c|c|c|c|c|}
\hline \multirow{2}{*}{$\begin{array}{c}\text { Kategória } \\
\text { Category }\end{array}$} & \multicolumn{2}{|c|}{ LAJTA Project } & \multicolumn{2}{c|}{ MOSON Project } \\
\cline { 2 - 5 } & ter. \% & red. ter. \% & ter. \% & red. ter. \% \\
\hline \hline $\mathbf{5 .}$ & $36,70(\times 1,00)$ & 36,70 & $67,85(\times 1,00)$ & 67,85 \\
\hline $\mathbf{4 .}$ & $11,49(\times 0,75)$ & 8,62 & $14,37(\times 0,75)$ & 10,78 \\
\hline $\mathbf{3 .}$ & $11,45(\times 0,50)$ & 5,73 & $0(\times 0,50)$ & 0 \\
\hline $\mathbf{2 .}$ & $16,44(\times 0,25)$ & 4,11 & $0(\times 0,25)$ & 0 \\
\hline $\mathbf{1 .}$ & $23,92(\times 0,00)$ & 0 & $17,78(\times 0,00)$ & 0 \\
\hline Összesen - Total & 100,00 & $\mathbf{5 6 , 1 6 \%}$ & 100,00 & $\mathbf{7 8 , 6 3 \%}$ \\
\hline
\end{tabular}

\section{MOSONI-SÍK}

\subsection{A túzok élőhelyhasználata és választása a Mosoni-síkon 2005-ben}

A Mosoni-sík áprilisi, augusztusi és decemberi élőhelykínálatának mvizsgálata alapján a tavaszi, illetve a téli időszakban az őszi búza, illetve a szántás dominált, míg a nyári periódusban a tarló volt a meghatározó élőhely-típus (1. ábra). A túzok számára fontos volt továbbá, az ősztől tavaszig mintegy $6,5 \%$ borítású repce megléte. A kisebb dominanciával jelen lévő, a Mosoni-síkra jellemző jellegzetes élőhely az un. túzokföld (ugar jellegü élőhely) bírt kiemelkedő jelentőséggel. A terület részletes tavaszi minősítése viszonylag alacsony, 56,67\%-ot értéket eredményezett (3. táblázat). Ez többek közt annak tudható be, hogy a Mosoni-sík teljes egésze monitoring terület, így a fenti érték közel $6 \%$ erdőt, valamint $21 \%$ szántást is tartalmazott. A legkedveltebb fészkelési élöhely mindazonáltal a fent említett túzokföld lett.

A Mosoni-síkon a túzok a tavaszi (költési) időszakban, valamint a nyári hónapokban az ugar (set-aside) jellegü ,túzokföld” élőhelyet részesítette előnyben (2. ábra), amelyet a számított IVLEV-indexek (3. ábra) is alátámasztanak. A téli hónapokban ezzel szemben a repce vált preferált élőhellyé. 


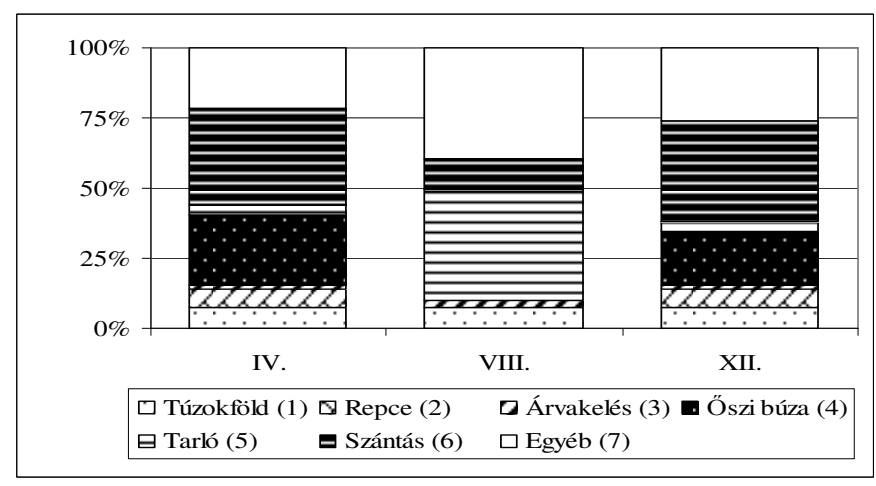

1. ábra: A Mosoni-sík élőhelykínálata (2005)

Figure 1: Habitat availability of the Moson-plain (2005)

(1) Set-aside, (2) Rape, (3) Volunteer crop, (4) Winter wheat, (5) Stubble, (6) Plouughed field, (7) Other

\section{3. táblázat: A Mosoni-sík élőhelyeinek minősítése tavasszal (2005)}

Table 3: Qualification of habitats of the Moson-plain in spring (2005)

\begin{tabular}{|l|c|c|c|}
\hline \multicolumn{1}{|c|}{ Élöhely / Habitat } & $\begin{array}{c}\text { Terület } \\
\text { / Area \% }\end{array}$ & $\begin{array}{c}\text { Kategória/ } \\
\text { Category }\end{array}$ & $\begin{array}{c}\text { Red. terület } \\
\text { /Red.area \% }\end{array}$ \\
\hline Fasor / Tree line & $0,13 \%$ & 1 & $0,00 \%$ \\
\hline Öszi búza / Winter wheat & $31,14 \%$ & 5 & $31,14 \%$ \\
\hline Öszi árpa / Winter barley & $3,81 \%$ & 5 & $3,81 \%$ \\
\hline Tavaszi árpa / Spring barley & $8,85 \%$ & 5 & $8,85 \%$ \\
\hline Rozs / Rye & $0,03 \%$ & 5 & $0,03 \%$ \\
\hline Zab / Oat & $0,07 \%$ & 5 & $0,07 \%$ \\
\hline Repce / Rape & $4,41 \%$ & 4 & $3,31 \%$ \\
\hline Borsó / Pea & $0,02 \%$ & 4 & $0,02 \%$ \\
\hline Hagyma / Onion & $0,02 \%$ & 1 & $0,00 \%$ \\
\hline Erdösáv / Forest belt & $4,04 \%$ & 1 & $0,00 \%$ \\
\hline Facélia / Phacelia & $2,83 \%$ & 1 & $0,00 \%$ \\
\hline Lucerna / Alfalfa & $3,71 \%$ & 1 & $0,00 \%$ \\
\hline Gyep /grassland & $0,24 \%$ & 5 & $0,24 \%$ \\
\hline Burgonya / Potato & $0,06 \%$ & 1 & $0,00 \%$ \\
\hline Erdő / Forest & $5,21 \%$ & 1 & $0,00 \%$ \\
\hline Ösgyep (magas füvü) / & $0,23 \%$ & 5 & $0,23 \%$ \\
\hline Vetett gyep / Seeded grass & $0,09 \%$ & 1 & $0,00 \%$ \\
\hline Csemetés erdötelepítés / & $0,07 \%$ & 1 & $0,00 \%$ \\
\hline Útpadka / Roadsides & $0,12 \%$ & 1 & $0,00 \%$ \\
\hline Anyaggödör / Strip mine & $0,81 \%$ & 1 & $0,00 \%$ \\
\hline Trágyadepó / Muck-depot & $0,08 \%$ & 1 & $0,00 \%$ \\
\hline Árokpart / Ditch-side & $0,09 \%$ & 1 & $0,00 \%$ \\
\hline Müút / Surfaced road & $0,27 \%$ & 1 & $0,00 \%$ \\
\hline Ruderália / Ruderalia & $0,06 \%$ & 5 & $0,06 \%$ \\
\hline Tarló (egyéb) / Stubble & $0,44 \%$ & 1 & $0,00 \%$ \\
\hline Vadföld / Partridge field & $0,09 \%$ & 5 & $0,09 \%$ \\
\hline Major / Farm & $0,88 \%$ & 1 & $0,00 \%$ \\
\hline Túzokföld / Set-aside & $7,73 \%$ & 5 & $7,73 \%$ \\
\hline Parlag / Fallow & $1,09 \%$ & 5 & $1,09 \%$ \\
\hline Szántás /Ploughed field & $21,34 \%$ & 1 & $0,00 \%$ \\
\hline Egyéb növényzet / Other & $1,68 \%$ & 1 & $0,00 \%$ \\
\hline Egyéb objektum / Other & $0,35 \%$ & 1 & $0,00 \%$ \\
\hline Összesen /Total & $\mathbf{1 0 0 , 0 0}$ & & $\mathbf{5 6 , 6 7 \%}$ \\
\hline
\end{tabular}




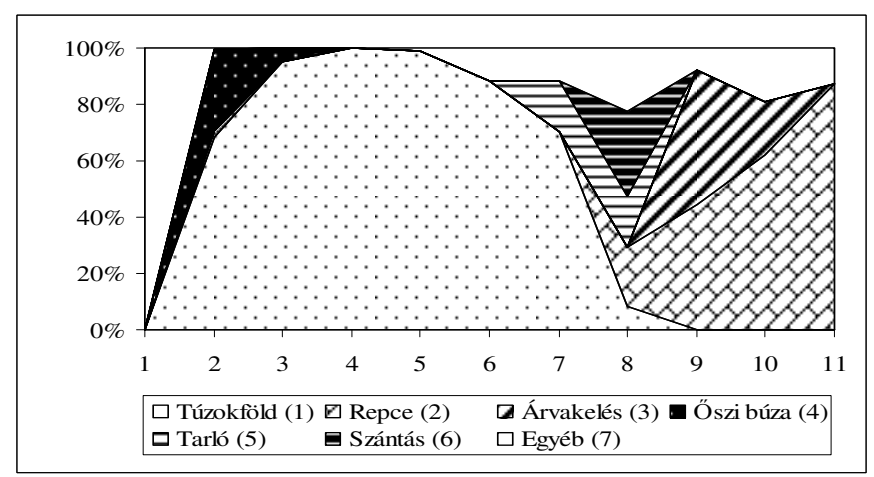

2. ábra: A túzok élőhelyhasználata a Mosoni-síkon (2005)

Figure 2: Habitat use of the Great Bustard of the Moson-plain (2005)

(1) Set-aside, (2) Rape, (3) Volunteer crop, (4) Winter wheat, (5) Stubble, (6) Ploughed field, (7) Other

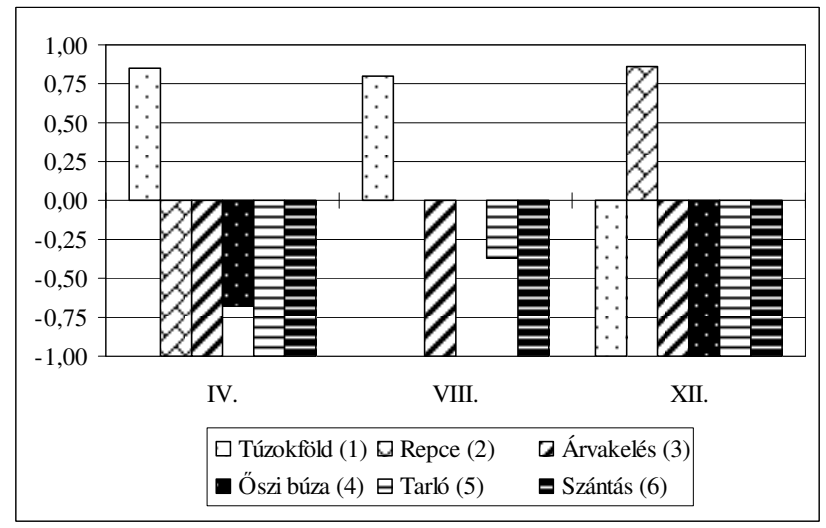

3. ábra: A túzok élőhelyválasztása (IVLEV-index) a Mosoni-síkon (2005)

Figure 3: IVLEV's electivity index of Great Bustard in the Moson-plain (2005)

(1) Set-aside, (2) Rape, (3) Volunteer crop, (4) Winter wheat, (5) Stubble, (6) Pluughed field

\subsection{A túzok élőhelyhasználata és választása a Mosoni-síkon 2006-ban}

A Mosoni-síkon az egyes élőhelytípusok százalékban kifejezett arányát, a 4. ábra ismerteti. A terület - túzok szempontjából - legfontosabb része, az É-i oldalon található pihentetett „,set aside" (ugar) terület, amely az év nagy részén a túzok által leglátogatottabb terület a Mosonisíkon.

A túzok által az őszi és téli hónapokban a repce bizonyult a legkedvezőbbnek (5. ábra). A költési időszakban ezzel szemben a pihentetett ugar volt a leglátogatottabb. A nyár végi hónapokban emellett a tarlók bizonyultak különösen kedvelt élőhelynek. Az élőhely használat és élőhely kínálat alapján számított IVLEV-indexek eredményei alapján (6. ábra) is a fenti megállapításokat erösíthetjük meg, a tavaszi set-aside, nyári tarló, valamit téli repce preferenciája bizonyosodott be.

$\mathrm{Az}$ élőhelykezelési problémák, elsősorban a természetes gyepek visszaszorulása, valamint a fokozott agrártevékenység miatt, a Mosoni-síkon kiemelt jelentősége van a túzokvédelem szempontjából annak, hogy ismerjük a faj élőhelypreferenciáját. Az ennek figyelembevételével kezelt élőhelyek bizonyítottan megalapozói voltak a faj sikeres megmentésének a térségben. 


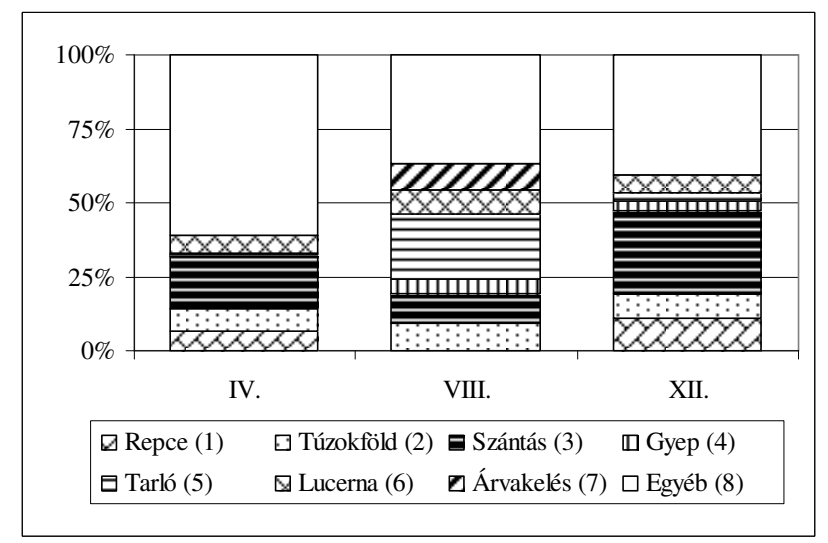

4. ábra: A Mosoni-síki monitoring terület élőhelykínálata (2006)

Figure 4: Habitat availability in the Mosoni-plain (2006)

(1) Rape, (2) Set-aside, (3) Ploughed field, (4) Grassland, (5) Stubble, (6) Alfalfa, (7) Volunteer crop, (8) Other

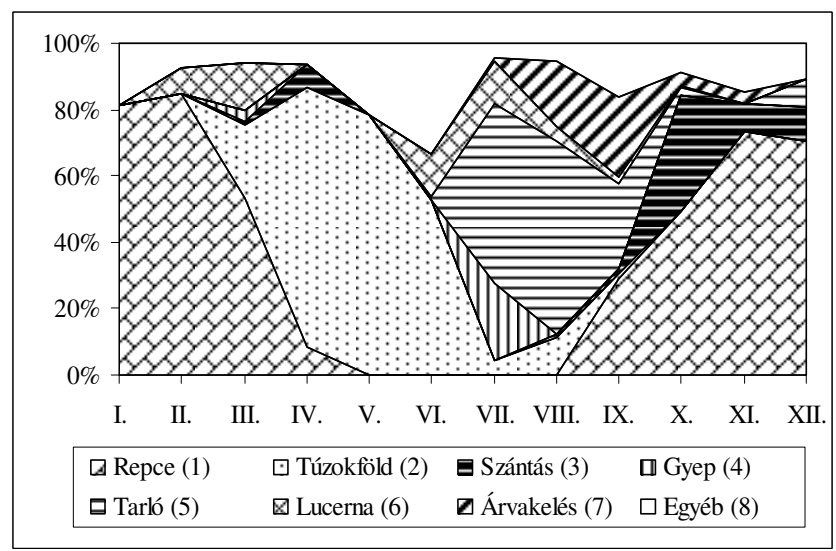

\section{5. ábra: A túzok élőhelyhasználata a Mosoni-síkon (2006)}

Figure 5: Habitat use of the Great Bustard in the Mosoni-plain (2006)

(1) Rape, (2) Set-aside, (3) Ploughed field, (4) Grassland, (5) Stubble, (6) Alfalfa, (7) Volunteer crop, (8) Other

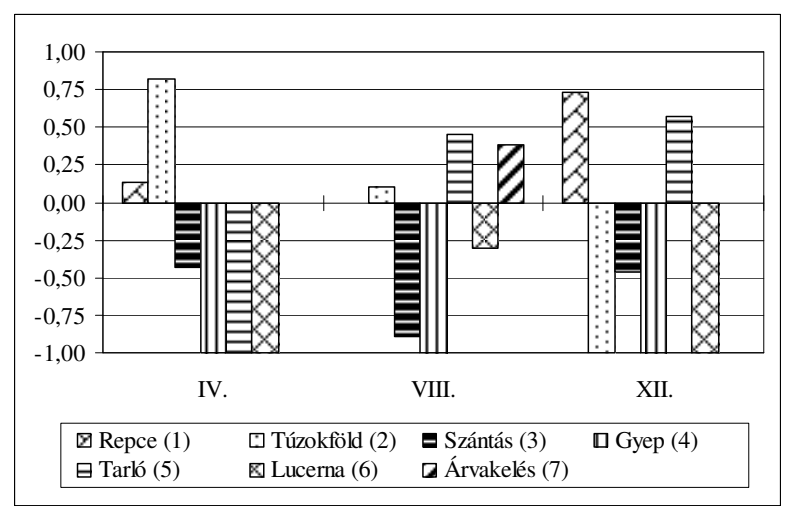

\section{6. ábra: A túzok élőhelyválasztása (IVLEV index) a Mosoni-síkon (2006)}

Figure 6: IVLEV's electivity index of Great Bustard in the Mosoni-plain (2006)

(1) Rape, (2) Fallow, (3) Ploughed field, (4) Grassland, (5) Stubble, (6) Alfalfa, (7) Volunteer crop

A Mosoni-sík fészkelés szempontjából releváns, tavaszi minősítése során (4. táblázat) a legmagasabb, 5-ös osztályba tartoztak a set-aside területek, valamint az ÉTT támogatásban 
részesülő, túzokbarát módon kezelt gabonaföldek. A terület 42,52\%-os minősítési értéke nem nevezhető magasnak, de az értéket csökkenti az a tény is, hogy a számításokat az egész Mosoni-síkra végeztük, ahol jelentős területeken találhatók fészkelésre alkalmatlan területek (erdő, egyéb területek, stb.). A terület északi részén elhelyezkedő MOSON-Project mintaterület élőhelyei ugyanakkor biztonságos fészkelöhelyei a térségnek.

4. táblázat: A Mosoni-sík élőhelyeinek minősítése tavasszal (2006)

Table 4: Qualification of habitats of the Mosoni-plain in spring (2006)

\begin{tabular}{|l|c|c|c|}
\hline \multicolumn{1}{|c|}{ Élöhely / Habitat } & $\begin{array}{c}\text { Terület / } \\
\text { Area \% }\end{array}$ & $\begin{array}{c}\text { Kategória/ } \\
\text { Category }\end{array}$ & $\begin{array}{c}\text { Red. terület } \\
\text { /Red.area \% }\end{array}$ \\
\hline Nem ÉTT gabona /cereals (out of ESA) & 21,79 & 4 & $16,34 \%$ \\
\hline ÉTT gabona / ETT cereals & 13,61 & 5 & $13,61 \%$ \\
\hline Szántás / ploughed field & 17,88 & 1 & $0 \%$ \\
\hline Set-aside & 7,73 & 5 & $7,72 \%$ \\
\hline Lucerna / alfalfa & 6,48 & 1 & $0 \%$ \\
\hline Repce / rape & 6,46 & 4 & $4,84 \%$ \\
\hline Erdö/erdösáv / forest (belt) & 9,23 & 1 & $0 \%$ \\
\hline Egyéb / other & 16,82 & 1 & $0 \%$ \\
\hline Összesen /Total & $\mathbf{1 0 0 , 0 0 \%}$ & & $\mathbf{4 2 , 5 2 \%}$ \\
\hline
\end{tabular}

\subsection{A túzok élőhelyhasználata és választása a Mosoni-síkon 2007-ben}

A Mosoni-sík élőhely-kínálatának vizsgálatakor azt a körülményt is figyelembe kellett venni, hogy a térségben nem került kijelölésre külön monitoring terület, hanem az egész $(112,18$ $\mathrm{km}^{2}$ ) élőhely felvételezésre került az élőhelykínálat megállapításakor. A teljes terület $22 \%$-át őszi búza borította áprilisban, decemberben ennek aránya $28 \%$ volt (7. ábra). A nyári időszakban ezzel szemben a tarlók (17\%) és árvakelések (22\%) aránya dominált. A set-aside jellegü „túzokföld” területek mindhárom időszakban $8 \%$ körüli értéket mutattak.

A túzok élőhelyhasználata (8. ábra) a túzokföld (tavaszi-nyári hónapok) és a repce (ősz-tél) dominanciáját mutatták. Szeptember-októberben emellett az árvakelés is gyakran használt élőhelynek bizonyult. Az élőhelyválasztási értéksor (IVLEV-index), alapján tisztább képet kapunk az élőhelykínálat és használat viszonyáról. Ez alapján elmondható, hogy a túzokföld mellett tavasszal az árvakelés volt választott élőhely, augusztusban csak a set-aside

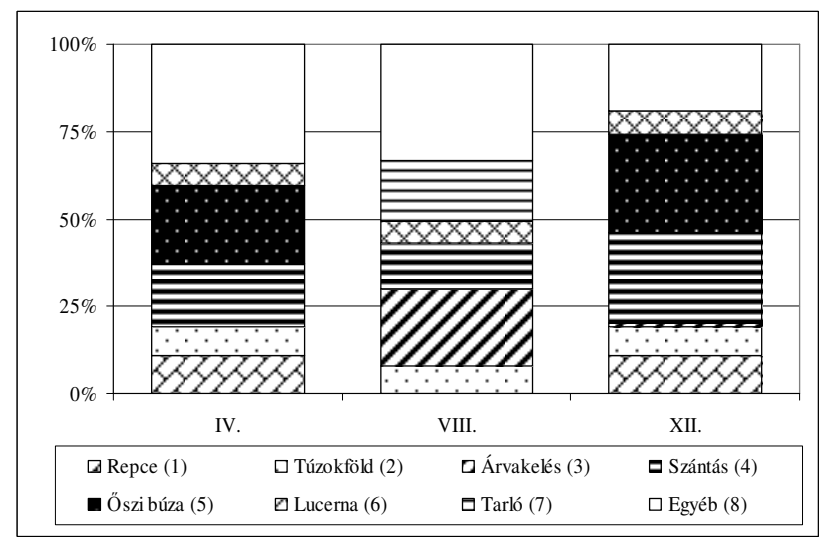

7. ábra: A Mosoni-síki monitoring terület élőhelykínálata (2007)

Figure 7: Habitat availability in the Mosoni-plain (2007)

(1) Rape, (2) Set-aside, (3) Volunteer-crop, (4) Ploughed field 
(5) Winter wheat, (6) Alfalfa, (7) Stubble, (8) Other

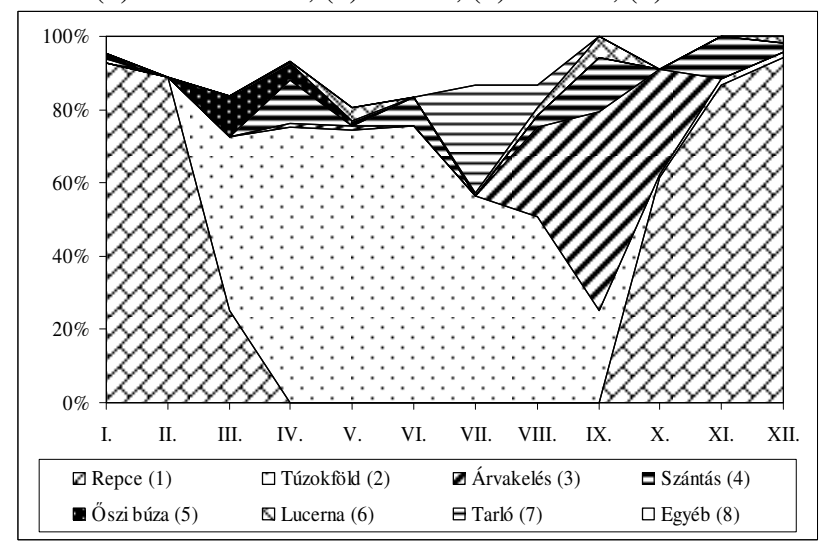

8. ábra: A túzok élőhelyhasználata a Mosoni-síkon (2007)

Figure 8: Habitat use of the Great Bustard in the Mosoni-plain (2007)

(1) Rape, (2) Set-aside, (3) Volunteer-crop, (4) Ploughed field,

(5) Winter wheat, (6) Alfalfa, (7) Stubble, (8) Other

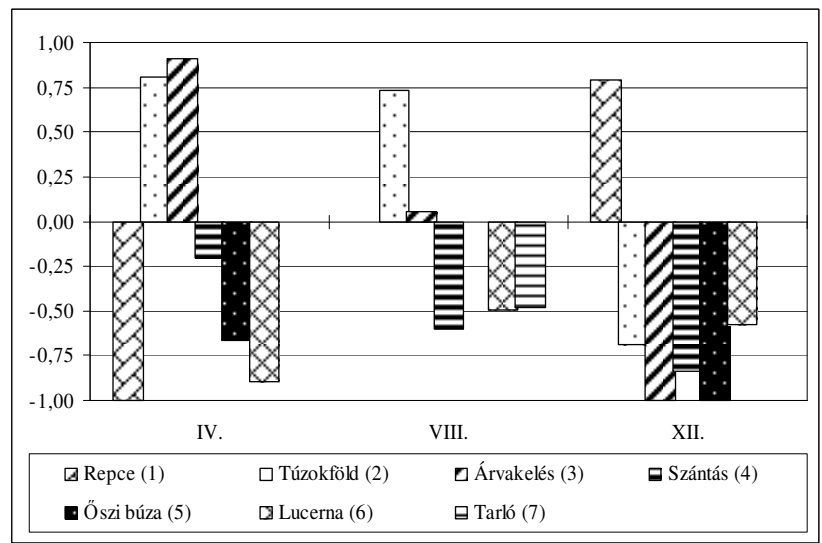

9. ábra: A túzok élőhelyválasztása (IVLEV index) a Mosoni-síkon (2007)

Figure 9: IVLEV's electivity index of Great Bustard in the Mosoni-plain (2007)

(1) Rape, (2) Set-aside, (3) Volunteer-crop, (4) Ploughed field,

(5) Winter wheat, (6) Alfalfa, (7) Stubble, (8) Other

5. táblázat: A Mosoni-síki élőhelyeinek minősítése tavasszal (2007)

Table 5: Qualification of habitats of the Mosoni-plain in spring (2007)

\begin{tabular}{|l|c|c|c|}
\hline \multicolumn{1}{|c|}{ Élőhely / Habitat } & $\begin{array}{c}\text { Terület } \\
\text { /Area \% }\end{array}$ & $\begin{array}{c}\text { Kategória/ } \\
\text { Category }\end{array}$ & $\begin{array}{c}\text { Red. terület } \\
\text { /Red.area \% }\end{array}$ \\
\hline Öszi árpa/winter barley & $12,40 \%$ & 5 & $12,40 \%$ \\
\hline Öszi búza/winter wheat & $12,20 \%$ & 5 & $12,20 \%$ \\
\hline Tritikálé/triticale & $1,87 \%$ & 5 & $1,87 \%$ \\
\hline Szántás/ploughed field & $17,88 \%$ & 1 & $0,00 \%$ \\
\hline Set-aside & $7,73 \%$ & 5 & $7,73 \%$ \\
\hline Lucerna/alfalfa & $6,43 \%$ & 1 & $0,00 \%$ \\
\hline Repce/rape & $10,99 \%$ & 4 & $8,24 \%$ \\
\hline Erdö/forest & $9,23 \%$ & 1 & $0,00 \%$ \\
\hline Egyéb/other & $21,27 \%$ & 1 & $0,00 \%$ \\
\hline Összesen /Total & $\mathbf{1 0 0 , 0 0 \%}$ & & $\mathbf{4 2 , 4 4 \%}$ \\
\hline
\end{tabular}


jellegű terület bizonyult kiemelkedően választott kultúrának, télen pedig szokásosan a repce preferenciáját tapasztaltuk (9. ábra). A terület minősítése 44,44\% értéket adott (5. táblázat), ami a fent említett tényezőknek (,egyéb” kategória: 21,27\%) tudható be.

\subsection{A túzok élőhelyhasználata és választása a Mosoni-síkon 2008-ban}

A Mosoni-sík élőhelykínálata 2008 tavaszán a 2007 évben tapasztaltakhoz hasonló módon alakult. A legnagyobb arányban előforduló kultúra ezúttal is az őszi gabona volt, 29\%-os borítással (10. ábra). A szántások 19\%-ot, a repcetáblák 11\%-ot adtak. A túzokföld aránya ezúttal is $8 \%$ közelében alakult. A túzok élőhelyhasználatát ezúttal is a repce és túzokföld dominanciája határozott meg (11. ábra).

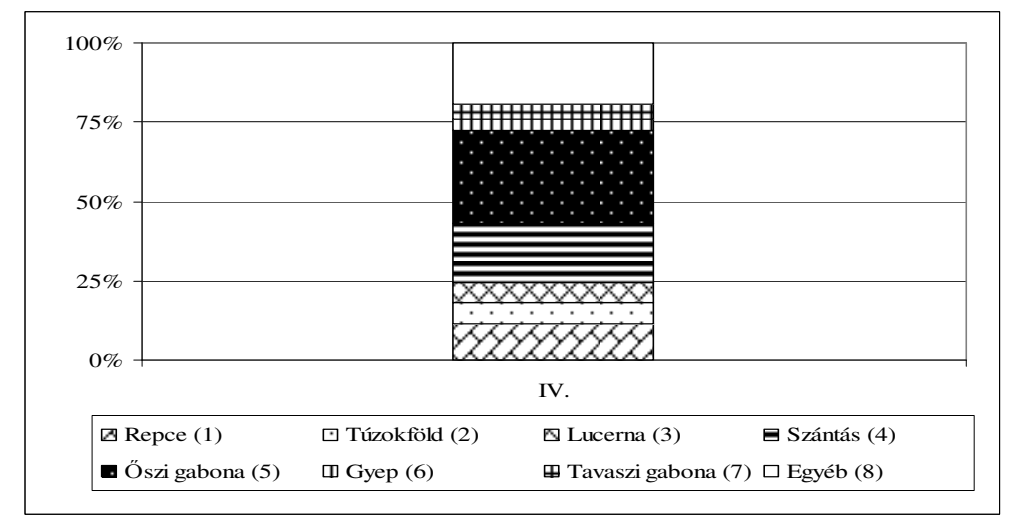

10. ábra: A Mosoni-sík monitoring terület élőhelykínálata (2008)

Figure 10: Habitat availability in Mosoni-plain (2008)

(1) Rape, (2) Set-aside, (3) Alfalfa, (4) Ploughed field, (5) Winter cereals, (6) Grassland, (7) Spring cereals, (8) Other

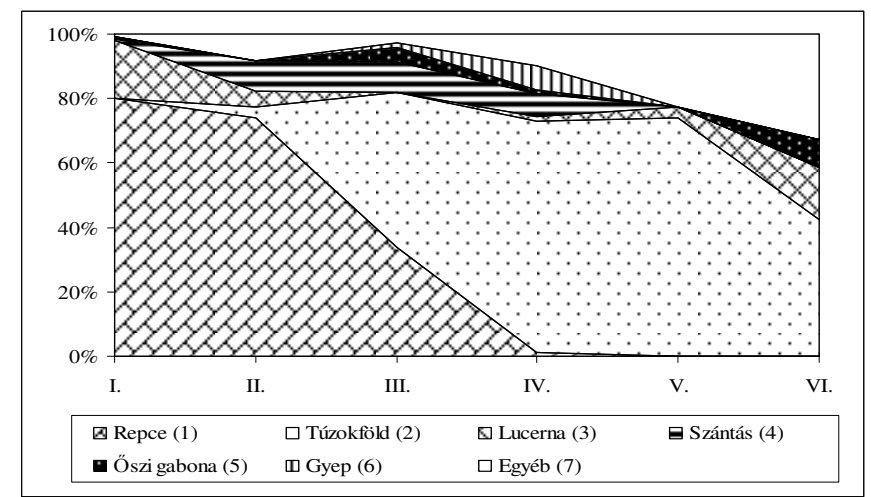

11. ábra: A túzok élőhelyhasználata a Mosoni-síkon (2008)

Figure 11: Habitat use of the Great Bustard in Mosoni-plain (2008)

(1) Rape, (2) Set-aside, (3) Alfalfa, (4) Ploughed field,

(5) Winter cereals, (6) Grassland, (7) Other

Az élőhelyválasztási adatok egyértelmúen a fent említett állapotokat igazolják, kiemelve a tavaszi időszakban elsősorban a túzokföld, másodsorban a repce preferenciáját (12. ábra).

A 2008-as év tavaszi élőhelyminősítése magasabb értéket mutatott, mint a 2007-es. Az 52,39\%-os értéke elsősorban a gabonák magas arányának volt köszönhető (6. táblázat). A Mosoni-síkon hagyományosan szoros kapcsolat alakult ki a gazdálkodókkal, részben ennek, részben a „túzokföld” élőhely fészkelési időszakban tapasztalt preferáltságának köszönhetően kevés fészekpusztulás fordult elő a térségben. 


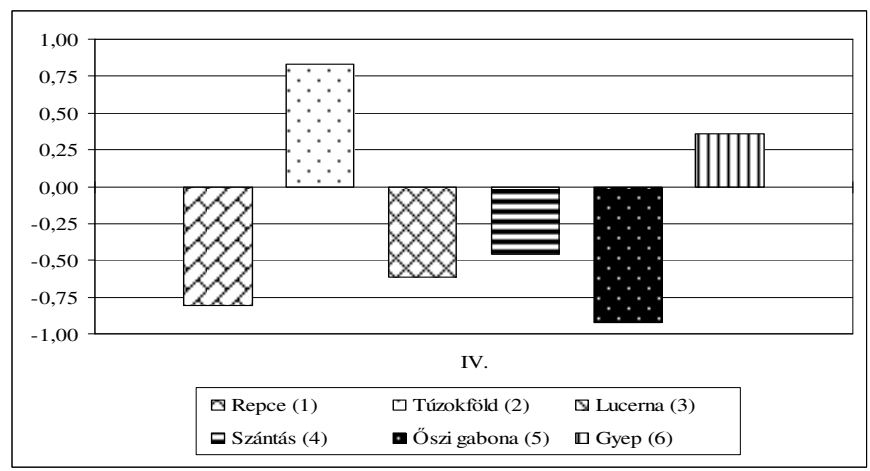

12. ábra: A túzok élőhelyválasztása (IVLEV index) a Mosoni-síkon (2008)

Figure 12: IVLEV's electivity index of Great Bustard in Mosoni-plain (2008)

(1) Rape, (2) Set-aside, (3) Alfalfa, (4) Ploughed field, (5) Winter cereals, (6) Grassland

6. táblázat: A Mosoni-sík élőhelyeinek minősítése tavasszal (2008)

Table 6: Qualification of habitats of the Mosoni-plain in spring (2008)

\begin{tabular}{|l|c|c|c|}
\hline \multicolumn{1}{|c|}{ Élőhely / Habitat } & $\begin{array}{c}\text { Terület } \\
\text { /Area \% }\end{array}$ & $\begin{array}{c}\text { Kategória } \\
\text { /Category }\end{array}$ & $\begin{array}{c}\text { Red. terület } \\
\text { /Red.area \% }\end{array}$ \\
\hline Őszi gabona/winter cereals & $28,96 \%$ & 5 & $28,96 \%$ \\
\hline Tavaszi gabona/spring cereals & $4,69 \%$ & 5 & $4,69 \%$ \\
\hline Gyep/grassland & $3,57 \%$ & 5 & $3,57 \%$ \\
\hline Szántás/ploughed field & $18,85 \%$ & 1 & $0,00 \%$ \\
\hline Set-aside & $6,72 \%$ & 5 & $6,72 \%$ \\
\hline Lucerna/alfalfa & $6,40 \%$ & 1 & $0,00 \%$ \\
\hline Repce/rape & $11,27 \%$ & 4 & $8,45 \%$ \\
\hline Erdő/forest & $7,97 \%$ & 1 & $0,00 \%$ \\
\hline Egyéb/other & $11,57 \%$ & 1 & $0,00 \%$ \\
\hline Összesen /Total & $\mathbf{1 0 0 , 0 0 \%}$ & & $\mathbf{5 2 , 3 9 \%}$ \\
\hline
\end{tabular}

\section{KISKUNSÁG}

\subsection{A túzok élőhelyhasználata és választása a Kiskunságban 2005-ben}

A kiskunsági mintaterület élőhelykínálatára a gyepek magas (>40\%) aránya volt jellemző, mely igen kedvező a túzok számára (13. ábra). A tavaszi időszakban emellett az őszi búza borítása volt kiemelkedő (24\%), amely adottságok hozzájárultak ahhoz, hogy a régió az ország legjobb fészkelöterületének számít. A terület 79,39\%-os minősítése (7. táblázat) a legmagasabb volt a 2005-ben tapasztalt hazai értékek között. A túzok területhasználatát a 14. ábra szemlélteti, az élőhelyválasztást jelző IVLEV-index értékeket a 15. ábra mutatja.

A 14 - 15. ábrák jól szemléltetik a túzok által a Kiskunságban preferált élöhelyeket. $\mathrm{Az}$ októbertől márciusig tartó időszakban elsősorban a repcesávokat látogatják, annak ellenére, hogy ez az élőhely-típus kevesebb, mint 3,5\%-át teszi ki a területnek. A költési időszakban, aztán a lucerna és a parlag vált preferált élőhellyé. A nyári hónapokban emellett a szántásokat részesítette előnyben a faj. 


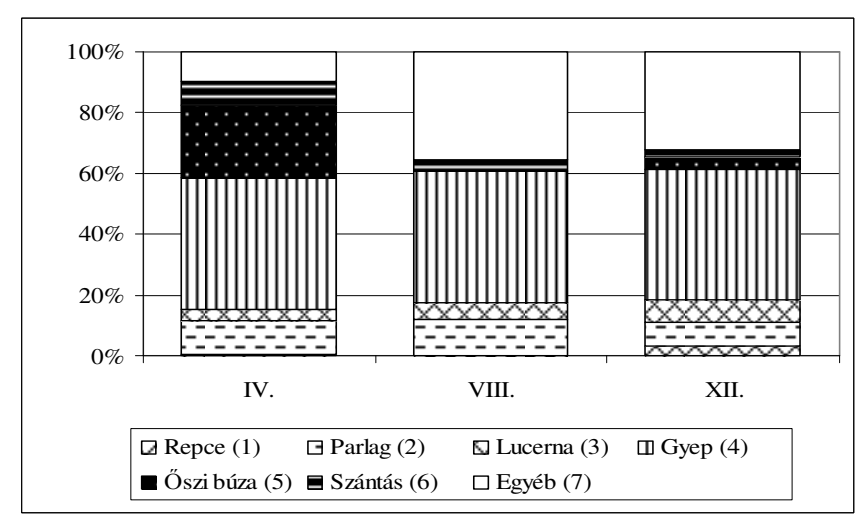

\section{3. ábra: A Kiskunság élőhelykínálata (2005)}

Figure 13: Habitat availability of the Kiskunság (2005)

(1) Rape, (2) Fallow, (3) Alfalfa, (4) Grassland, (5) Winter wheat, (6) Ploughed field, (7) Other

7. táblázat: A Kiskunság élőhelyek minősítése tavasszal (2005)

Table 7: Qualification of habitats of the Kiskunság in spring (2005)

\begin{tabular}{|l|c|c|c|}
\hline \multicolumn{1}{|c|}{ Élöhely / Habitat } & $\begin{array}{c}\text { Terület / Area } \\
\%\end{array}$ & $\begin{array}{c}\text { Kategória } \\
\text { /Category }\end{array}$ & $\begin{array}{c}\text { Red. terület } \\
\text { /Red.area \% }\end{array}$ \\
\hline Erdö / Forest & $1,86 \%$ & 1 & $0,00 \%$ \\
\hline Szántás / Ploughed field & $8,14 \%$ & 1 & $0,00 \%$ \\
\hline Öszi búza / Winter wheat & $23,96 \%$ & 5 & $23,96 \%$ \\
\hline Öszi árpa / Winter barley & $0,92 \%$ & 5 & $0,92 \%$ \\
\hline Repce / Rape & $0,55 \%$ & 4 & $0,41 \%$ \\
\hline Kukorica / Maize & $0,28 \%$ & 3 & $0,14 \%$ \\
\hline Lucerna / Alfalfa & $3,84 \%$ & 1 & $0,00 \%$ \\
\hline Gyep / Grassland & $43,21 \%$ & 5 & $43,21 \%$ \\
\hline Vetett gyep / Seeded grass & $1,51 \%$ & 1 & $0,00 \%$ \\
\hline Gazos / Weedy & $0,37 \%$ & 1 & $0,00 \%$ \\
\hline Tarló (gabona) / Stubble (cereal) & $1,07 \%$ & 1 & $0,00 \%$ \\
\hline Tarló (kukorica) / Stubble (maize) & $1,25 \%$ & 1 & $0,00 \%$ \\
\hline Tanya / Farm & $0,44 \%$ & 1 & $0,00 \%$ \\
\hline Parlag / Follow & $10,76 \%$ & 5 & $10,76 \%$ \\
\hline Egyéb növ. / Other plant. & $1,87 \%$ & 1 & $0,00 \%$ \\
\hline Összesen /Total & $\mathbf{1 0 0 , 0 0 \%}$ & & $\mathbf{7 9 , 3 9 \%}$ \\
\hline
\end{tabular}

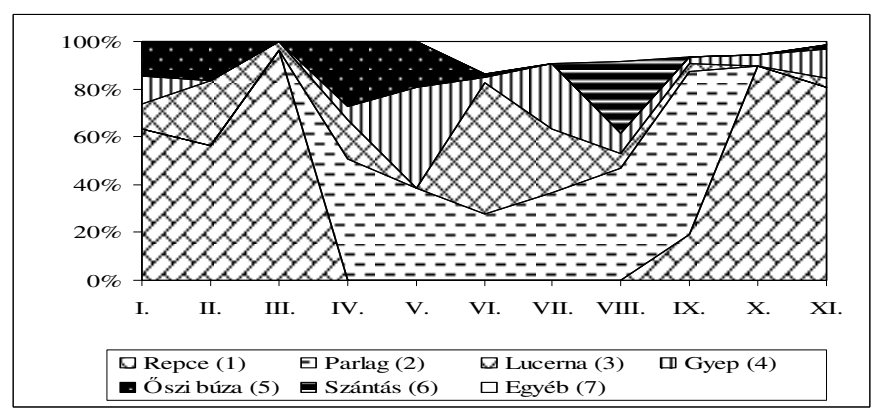

\section{4. ábra: A túzok élőhelyhasználata a Kiskunságban (2005)}

Figure 14: Habitat use of the Great Bustard of the Kiskunság (2005)

(1) Rape, (2) Fallow, (3) Alfalfa, (4) Grassland, (5) Winter wheat, (6) Ploughed field, (7) Other 


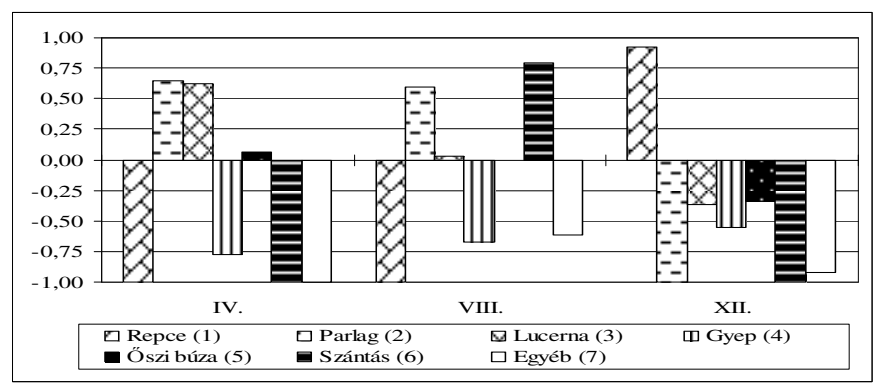

\section{5. ábra: A túzok élőhelyválasztása (IVLEV-index) a Kiskunságon (2005)}

Figure 15: IVLEV's electivity index of Great Bustard in the Kiskunság (2005)

(1) Rape, (2) Fallow, (3) Alfalfa, (4) Grassland, (5) Winter wheat, (6) Ploughed field, (7) Other

\subsection{A túzok élőhelyhasználata és választása a Kiskunságban 2006-ban}

A kiskunsági monitoring terület egyes élőhelytípusainak százalékos megoszlása alapján egész évben a gyepek szerepe volt a meghatározó, amelyek nagy része védelmet élvez. Emellett a parlagterületek, repce volt megtalálható nagyobb arányban. A tavasszal és télen szántásként nyilvántartott területek nagy részén, nyáron kukoricát, vagy silókukoricát vetettek (16. ábra).

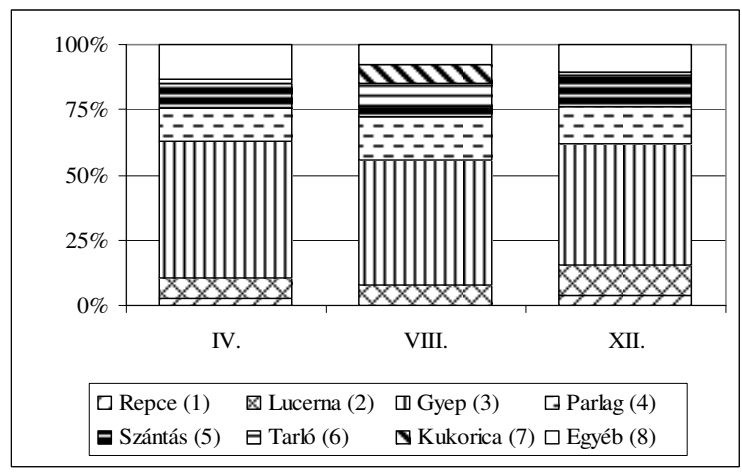

16. ábra: A kiskunsági monitoring terület élőhelykínálata (2006)

Figure 16: Habitat availability in the Kiskunság (2006)

(1) Rape, (2) Alfalfa, (3) Grassland, (4) Fallow, (5) Ploughed field, (6) Stubble, (7) Maize, (8) Other;

A monitoring területen megfigyelt túzokok élőhely használata alapján megállapítható, hogy azok a téli és az őszi hónapokban elsősorban a repcét és a gyepterületeket látogatták. A tradicionális dürgőhelyek nagy része a védett gyepekre esik, így ezt az élőhelytípust előszeretettel látogatták a dürgési időszakban. A gyepek használata nyáron is megmaradt, a repce helyett azonban elsősorban lucernán és a tarlókon tartózkodtak a madarak. A téli időszakban elsősorban a nagy kiterjedésü repcetáblákat látogatták a túzokok (17. ábra). A két fenti adatsor alapján kalkulált élőhely választás (IVLEV-index) értékeit elemezve megállapíthatjuk, hogy tavasszal a lucerna és a repce volt a leginkább preferált élőhely, emellett a tarlókat részesítették előnyben a madarak. Nyáron ezzel szemben a szántások index-értéke volt a legmagasabb, de továbbra is megmaradt a tarlók és a lucerna pozitív választása. Télen kizárólag a repcevetések, a faj jellegzetes telelőterületi bizonyultak preferált élőhelynek (18. ábra). 


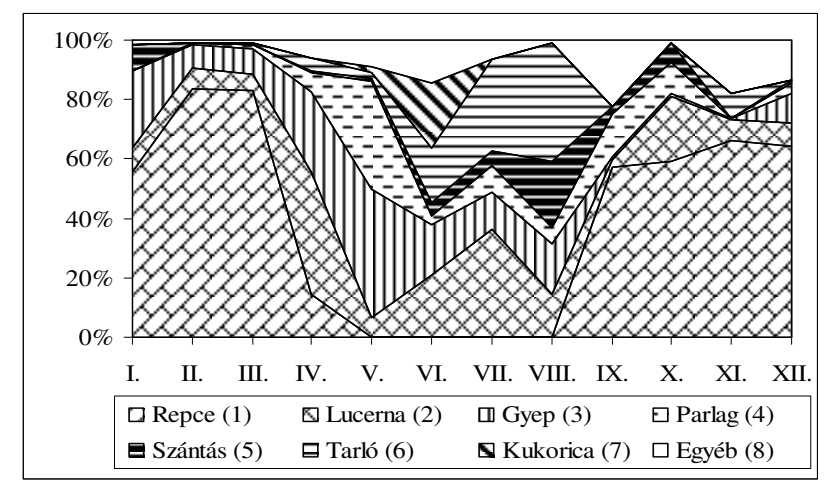

17. ábra: A túzok élőhelyhasználata a Kiskunságban (2006)

Figure 17: Habitat use of the Great Bustard in the Kiskunság (2006)

(1) Rape, (2) Alfalfa, (3) Grassland, (4) Fallow, (5) Ploughed field, (6) Stubble, (7) Maize, (8) Other;

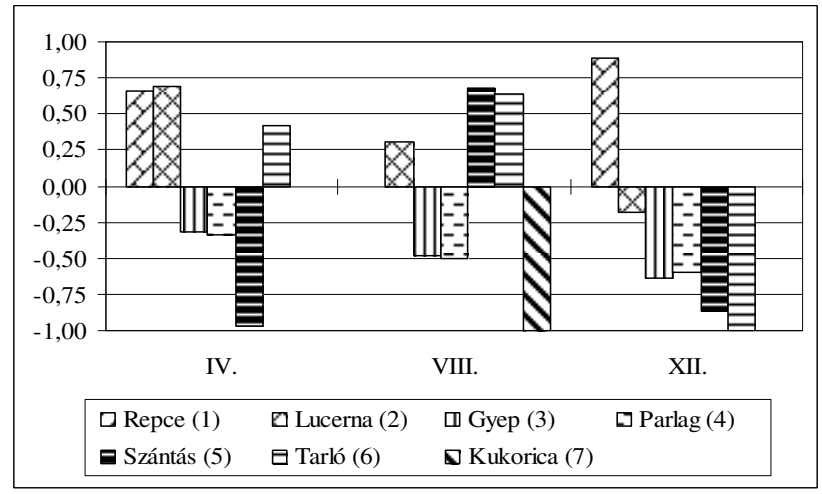

18. ábra: A túzok élőhelyválasztása (IVLEV index) a Kiskunságban (2006)

Figure 18: IVLEV's electivity index of Great Bustard in the Kiskunság (2006)

(1) Rape, (2) Alfalfa, (3) Grassland, (4) Fallow, (5) Ploughed field, (6) Stubble, (7) Maize

A kiskunsági terület fészkelési szempontból fontos tavaszi bonitási értéke magasnak tekinthető 76, 9\%, (8. táblázat), ami elsősorban a biztonságos költést biztosító 5-ös értékü gyepterületek magas arányának köszönhető. Emellett sok fészek került elö mezőgazdasági kultúrterületekből (őszi búza, lucerna, cukorrépa), amelyek „túzokbarát” kezelése elengedhetetlen a sikeres költések szempontjából.

8. táblázat: A kiskunsági élőhelyek minősítése tavasszal (2006)

Table 8: Qualification of habitats of the Kiskunság in spring (2006)

\begin{tabular}{|l|c|c|c|}
\hline \multicolumn{1}{|c|}{ Élöhely / Habitat } & $\begin{array}{c}\text { Terület } \\
\text { /Area \% }\end{array}$ & $\begin{array}{c}\text { Kategória } \\
\text { /Category }\end{array}$ & $\begin{array}{c}\text { Red. terület } \\
\text { /Red.area \% }\end{array}$ \\
\hline Gyep / grassland & 52,31 & 5 & $52,31 \%$ \\
\hline Parlag / fallow & 12,99 & 5 & $12,99 \%$ \\
\hline Szántás / ploughed field & 9,11 & 1 & $0,00 \%$ \\
\hline Lucerna / alfalfa & 7,50 & 1 & $0,00 \%$ \\
\hline Öszi árpa / winter barley & 5,93 & 5 & $5,93 \%$ \\
\hline Öszi búza / winter wheat & 3,46 & 5 & $3,46 \%$ \\
\hline Repce / rape & 2,94 & 4 & $2,21 \%$ \\
\hline Egyéb / other & 5,76 & 1 & $0,00 \%$ \\
\hline Összesen /Total & $\mathbf{1 0 0 , 0 0 \%}$ & & $\mathbf{7 6 , 9 0 \%}$ \\
\hline
\end{tabular}


A térségben tartott nagy tenyészállat létszám velejárójaként magas a lucerna aránya az agrárterületeken, amelyek döntő többsége az AKG program elöírásai szerint történik, így kedvezett a túzokok költésének.

\subsection{A túzok élőhelyhasználata és választása a Kiskunságban 2007-ben}

A kiskunsági monitoring területre a gyepek magas aránya volt jellemző 2007-ben is. Ennek értéke mindhárom vizsgált időszakban (április, augusztus, december) $40 \%$ és $50 \%$ között változott. Emellett a lucerna 12\% körüli aránya, és a parlagterületek (7-14\%) jellemezték mindhárom évszakot. A tavaszi és a téli hónapokban a fentiek mellett szántások adták a terület 11-14\%-át. Ezekben az időszakokban 3,5\% repce fedte a területet (19. ábra).

A legváltozatosabb élőhelyhasználattal a nyári hónapok voltak jellemezhetőek, míg az év vége felé haladva egyre inkább a repce vált meghatározó kultúrává. Januártól októberig $20 \%$ körül változott a lucerna használata, a költési időszakban emellett a gyepek és parlagterületek használata volt kiemelkedő (20. ábra).

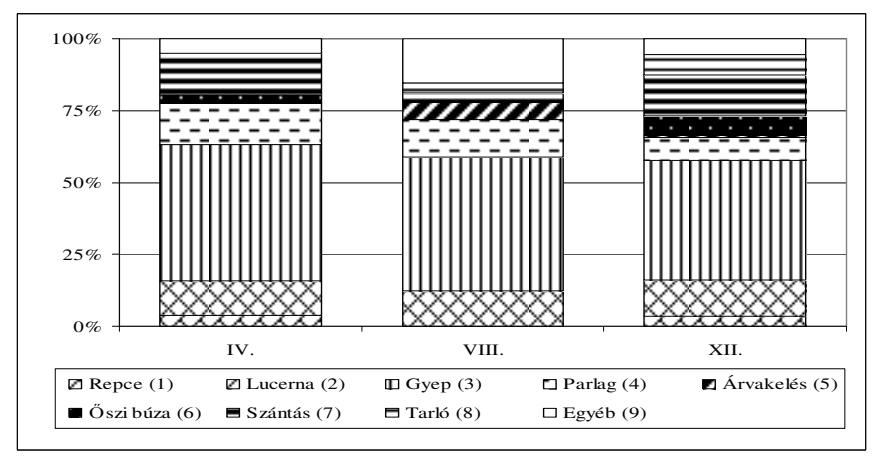

19. ábra: A Kiskunsági monitoring terület élőhelykínálata (2007)

Figure 19: Habitat availability in Kiskunság (2007)

(1) Rape, (2) Alfalfa, (3) Grassland, (4) Fallow, (5) Volunteer crop, (6) Winter wheat, (7) Ploughed field, (8) Stubble, (9) Other;

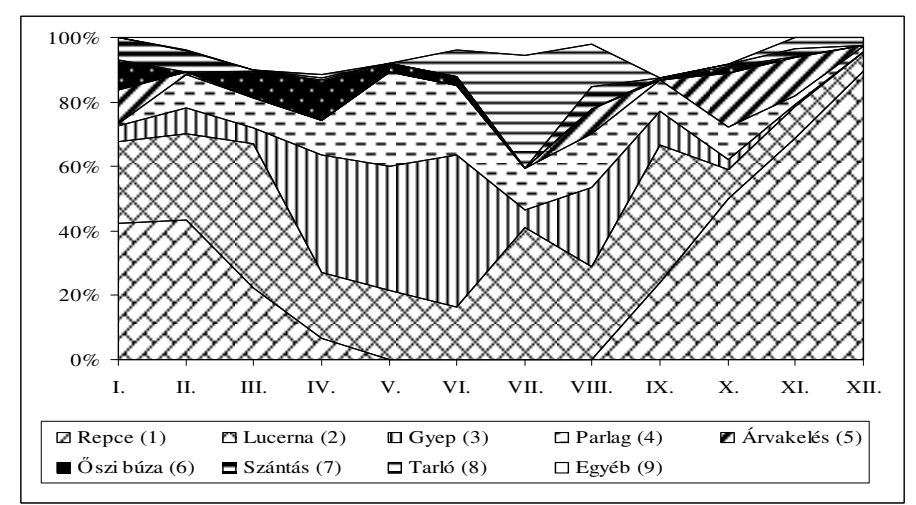

20. ábra: A túzok élőhelyhasználata a Kiskunságban (2007)

Figure 20: Habitat use of the Great Bustard in Kiskunság (2007)

(1) Rape, (2) Alfalfa, (3) Grassland, (4) Fallow, (5) Volunteer crop, (6) Winter wheat, (7) Ploughed field, (8) Stubble, (9) Other; 


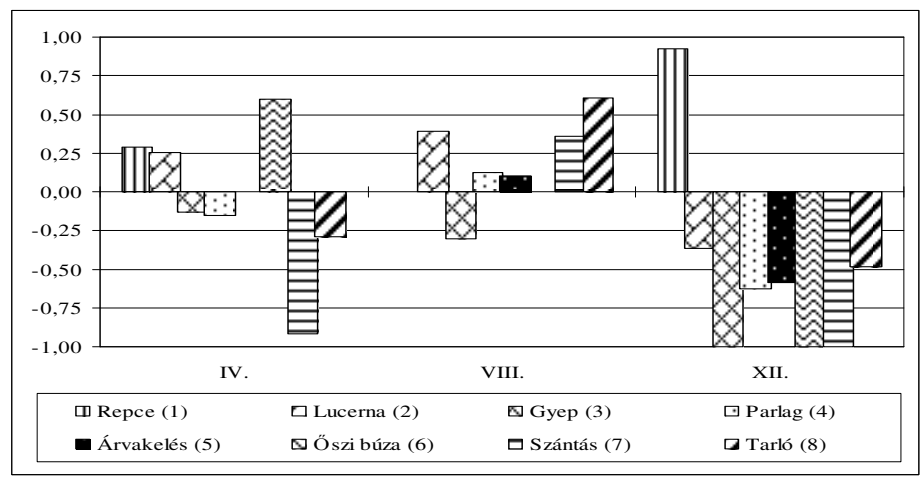

\section{1. ábra: A túzok élőhelyválasztása (IVLEV index) a Kiskunságban (2007)}

Figure 21: IVLEV's electivity index of Great Bustard in Kiskunság (2007)

(1) Rape, (2) Alfalfa, (3) Grassland, (4) Fallow, (5) Volunteer crop,

(6) Winter wheat, (7) Ploughed field, (8) Stubble,

Az IVLEV-index értékek (21. ábra) is a repce egyértelmü téli preferálását mutatják. A tavaszi időszakban ugyancsak kedvelt volt a repce - a lucerna és az őszi búza választása mellett. Augusztusban változatos élőhelyválasztási értékek mellett a tarlók bizonyultak a legpreferáltabb élőhely típusnak, míg ebben az időben kerülték a gyepeket.

9. táblázat: A kiskunsági élőhelyek minősítése tavasszal (2007)

Table 9: Qualification of habitats of the Kiskunság in spring (2007)

\begin{tabular}{|l|r|c|c|}
\hline \multicolumn{1}{|c|}{ Élőhely / Habitat } & $\begin{array}{c}\text { Terület / } \\
\text { Area \% }\end{array}$ & $\begin{array}{c}\text { Kategória } \\
\text { /Category }\end{array}$ & $\begin{array}{c}\text { Red. terület } \\
\text { /Red.area \% }\end{array}$ \\
\hline Gyep/grassland & $47,35 \%$ & 5 & $47,35 \%$ \\
\hline Parlag/fallow & $14,42 \%$ & 5 & $14,42 \%$ \\
\hline Szántás/ploughed field & $11,93 \%$ & 1 & $0,00 \%$ \\
\hline Lucerna/alfalfa & $12,21 \%$ & 1 & $0,00 \%$ \\
\hline Zab/oat & $2,15 \%$ & 5 & $2,15 \%$ \\
\hline Öszi búza/winter wheat & $3,18 \%$ & 5 & $3,18 \%$ \\
\hline Repce/rape & $3,63 \%$ & 4 & $2,72 \%$ \\
\hline Egyéb/other & $5,13 \%$ & 1 & $0,00 \%$ \\
\hline Összesen / Total & $\mathbf{1 0 0 , 0 0 \%}$ & & $\mathbf{6 9 , 8 2 \%}$ \\
\hline
\end{tabular}

A kiskunsági mintaterület fészkelési szempontú tavaszi minősítése 69,82\%-os eredményt adott, ami a 2006-os 76,9\%-os értékhez viszonyítva visszaesést jelentett. Ez elsősorban az őszi gabonák arányában tapasztalt csökkenésnek volt köszönhető (9. táblázat).

\subsection{A túzok élőhelyhasználata és választása a Kiskunságban 2008-ban}

A kiskunsági monitoring terület közel 50\%-át gyepek borították. Emellett 6-12\% között változott a parlagterületek, lucerna, őszi búza, szántások aránya (22. ábra).

A repce a vizsgált hónapban (április), mindössze 2,5\%-át fedte a monitoring területnek. A túzok élőhelyhasználatát megvizsgálva (23. ábra) elmondhatjuk, hogy a téli repce preferenciát a tavasz beköszöntével fokozatosan felváltják más kultúrák - lucerna, parlagterületek, gyepek. Május-június hónapban a gyep válik a legtöbbet használt élöhellyé, de itt figyelembe kell vennünk azt a tényt, hogy a gyepeken nagyobb esély van a madarak megfigyelésére, mind a magasabb takarást biztosító élőhelyeken. 


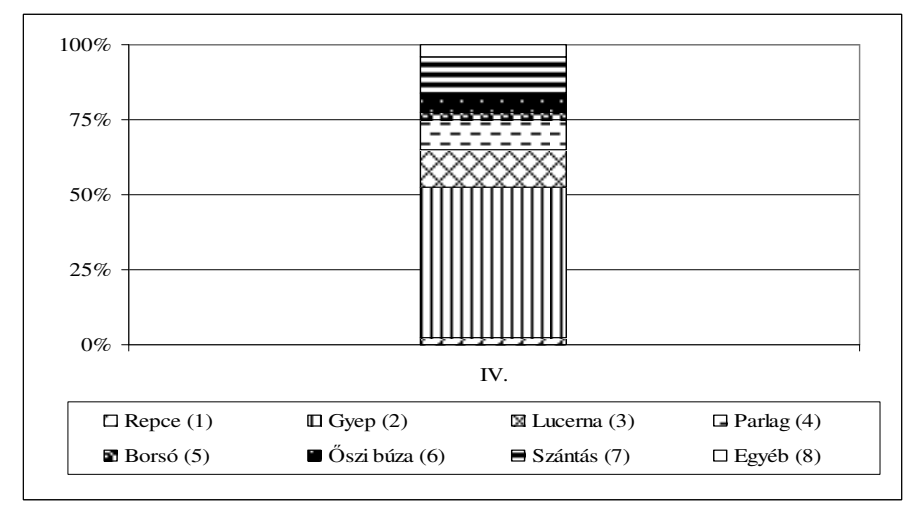

22. ábra: A Kiskunsági monitoring terület élőhelykínálata (2008)

Figure 22: Habitat availability in Kiskunság (2008)

(1) Rape, (2) Grassland, (3) Alfalfa, (4) Fallow, (5) Pea,

(6) Winter wheat, (7) Ploughed field, (8) Other

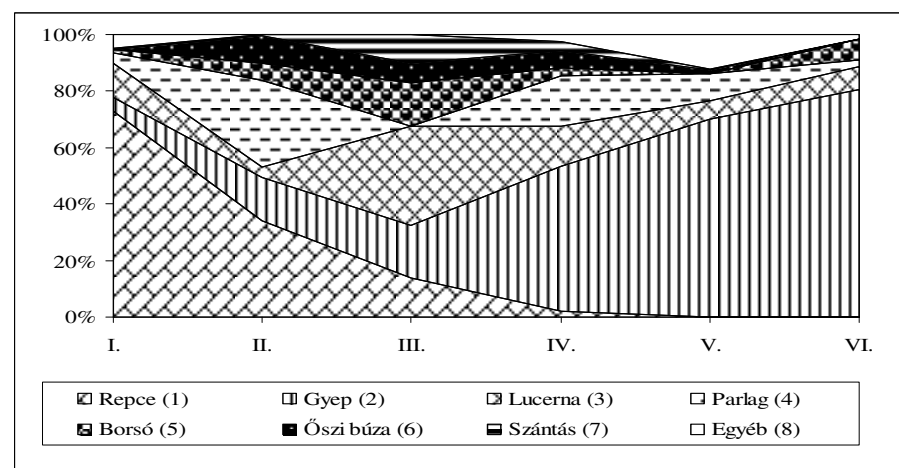

23. ábra: A túzok élőhelyhasználata a Kiskunságban (2008)

Figure 23: Habitat use of the Great Bustard in Kiskunság (2008)

(1) Rape, (2) Grassland, (3) Alfalfa, (4) Fallow, (5) Pea,

(6) Winter wheat, (7) Ploughed field, (8) Other

Az élőhelykínálat függvényében megvizsgált élőhelyhasználati értékek jól mutatják április hónapban a parlagterületek és a lucerna választását. A gyepterületek „,0" körüli értéke azt mutatja, hogy a kultúra borításával megegyező mértében voltak jelen a madarak ezen az élőhelytípuson, ugyanakkor a repcetáblákat és a szántásokat nem preferálták (24. ábra).

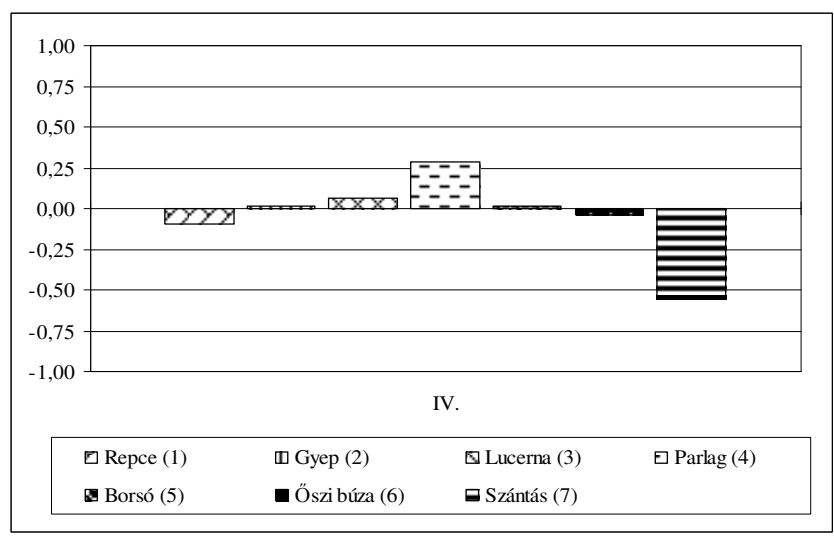

24. ábra: A túzok élőhelyválasztása (IVLEV index) a Kiskunságban (2008)

Figure 24: IVLEV's electivity index of Great Bustard in Kiskunság (2008)

(1) Rape, (2) Grassland, (3) Alfalfa, (4) Fallow, (5) Pea, (6) Winter wheat, (7) Ploughed field 
A kiskunsági terület fészkelési szempontú minősítése során nyert $70 \%$ feletti értéke (10. táblázat) magasnak mondható, ami elsősorban a természetes gyepek és parlagterületek magas arányának köszönhető. A lucerna aránya, hasonlóan a 2007-es évhez, 2008-ban is magas volt a korábbi évek viszonyaihoz képest. Az 5-ös kategóriát képviselő őszi gabonák sem nyújtottak biztonságos költőterületet a madarak számára, mivel többek között az aszály következtében a szokottnál korábban történtek meg az aratási munkálatok, ami több fészekalj pusztulását is okozta a térségben.

10. táblázat: A kiskunsági élőhelyek minősítése tavasszal (2008)

Table 10: Qualification of habitats of the Kiskunság in spring (2008)

\begin{tabular}{|l|c|c|c|}
\hline \multicolumn{1}{|c|}{ Élőhely / Habitat } & $\begin{array}{c}\text { Terület / } \\
\text { Area \% }\end{array}$ & $\begin{array}{c}\text { Kategória } \\
\text { /Category }\end{array}$ & $\begin{array}{c}\text { Red. terület } \\
\text { /Red.area \% }\end{array}$ \\
\hline Gyep/grassland & $49,75 \%$ & 5 & $49,75 \%$ \\
\hline Parlag/fallow & $9,88 \%$ & 5 & $9,88 \%$ \\
\hline Szántás/ploughed field & $11,86 \%$ & 1 & $0,00 \%$ \\
\hline Lucerna/alfalfa & $12,78 \%$ & 1 & $0,00 \%$ \\
\hline Zab/oat & $1,12 \%$ & 5 & $1,12 \%$ \\
\hline Öszi búza/winter wheat & $6,65 \%$ & 5 & $6,65 \%$ \\
\hline Borsó/pea & $2,50 \%$ & 4 & $1,88 \%$ \\
\hline Repce/rape & $1,69 \%$ & 4 & $1,27 \%$ \\
\hline Összesen / Total & $\mathbf{1 0 0 , 0 0 \%}$ & & $\mathbf{7 0 , 5 4 \%}$ \\
\hline
\end{tabular}

\section{SOLTI-SÍK}

\subsection{A túzok élőhelyhasználata és választása a Solti-síkon 2005-ben}

A Solti-sík élőhelykínálatát a gyepek magas aránya jellemezte 2005-ben (25. ábra). A tavaszi, illetve a nyári időszakban emellett az őszi búza aránya közelítette meg a 30\%-ot. A téli hónapokban utóbbi élőhelynek több mint felét szántás váltotta fel. A téli időszakban a madarak a repcét részesítették előnyben (26. ábra), amelyet a fészkelési időszakban a gyepek és az őszi búza dominanciája vált fel. A mintaterület fészkelés szempontú tavaszi minősítése magas $(67,67 \%)$ értéket mutatott (11. táblázat), amely jól jelzi, hogy a terület kifejezetten kedvező a faj számára.

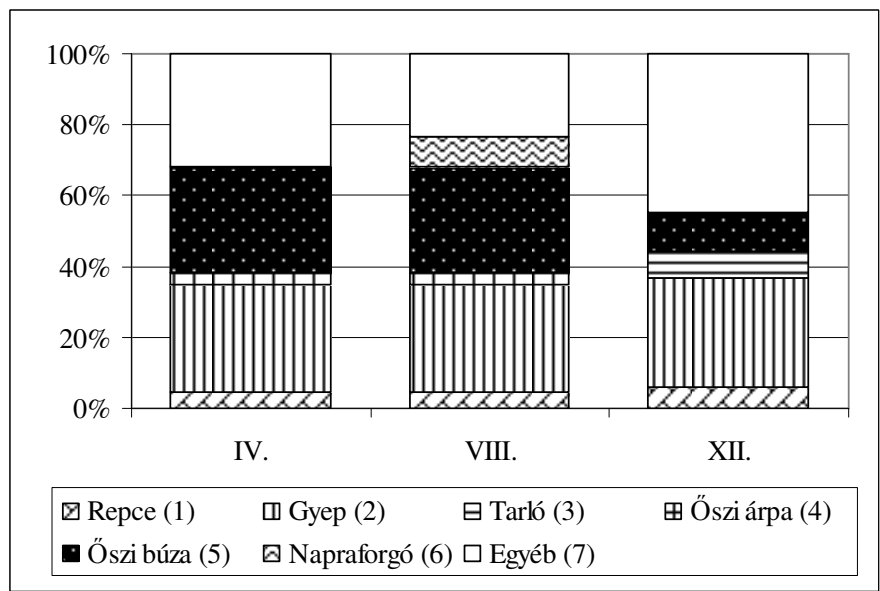

25. ábra: A Solti-sík élőhelykínálata (2005)

Figure 25: Habitat availability of the Solti-plain (2005)

(1) Rape, (2) Grassland, (3) Stubble field, (4) Winter barley, (5) Winter wheat, (6) Sunflower, (7) Other 


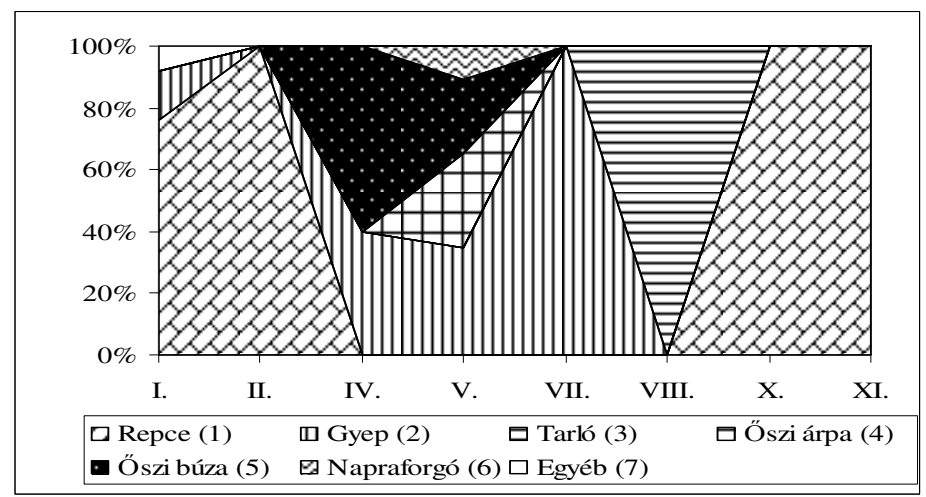

26. ábra: A túzok élőhelyhasználata a Solti-síkon (2005)

Figure 26: Habitat use of the Great Bustard of the Solti-plain (2005)

(1) Rape, (2) Grassland, (3) Stubble field, (4) Winter barley, (5) Winter wheat, (6) Sunflower, (7) Other

11. táblázat: A Solti-sík élőhelyeinek minősítése tavasszal (2005)

Table 11: Qualification of habitats of the Solti-plain in spring (2005)

\begin{tabular}{|l|c|c|c|}
\hline \multicolumn{1}{|c|}{ Élöhely / Habitat } & $\begin{array}{c}\text { Terület } \\
\text { / Area \% }\end{array}$ & $\begin{array}{c}\text { Kategória } \\
\text { /Category }\end{array}$ & $\begin{array}{c}\text { Red. terület } \\
\text { /Red.area \% }\end{array}$ \\
\hline Egyéb / Other & $0,02 \%$ & 1 & $0,00 \%$ \\
\hline Erdő / Forest & $0,04 \%$ & 1 & $0,00 \%$ \\
\hline Szántás / Ploughed field & $9,43 \%$ & 1 & $0,00 \%$ \\
\hline Öszi búza / Winter wheat & $29,95 \%$ & 5 & $29,95 \%$ \\
\hline Öszi árpa / Winter barley & $3,21 \%$ & 5 & $3,21 \%$ \\
\hline Repce / Rape & $4,24 \%$ & 4 & $3,18 \%$ \\
\hline Lucerna / Alfalfa & $7,86 \%$ & 1 & $0,00 \%$ \\
\hline Gyep / Grassland & $30,82 \%$ & 5 & $30,82 \%$ \\
\hline Nádszegély / Reed belt & $13,71 \%$ & 1 & $0,00 \%$ \\
\hline Tanya / Farm & $0,21 \%$ & 1 & $0,00 \%$ \\
\hline Parlag / Fallow & $0,51 \%$ & 5 & $0,51 \%$ \\
\hline Összesen / Total & $\mathbf{1 0 0 , 0 0 \%}$ & & $\mathbf{6 7 , 6 7 \%}$ \\
\hline
\end{tabular}

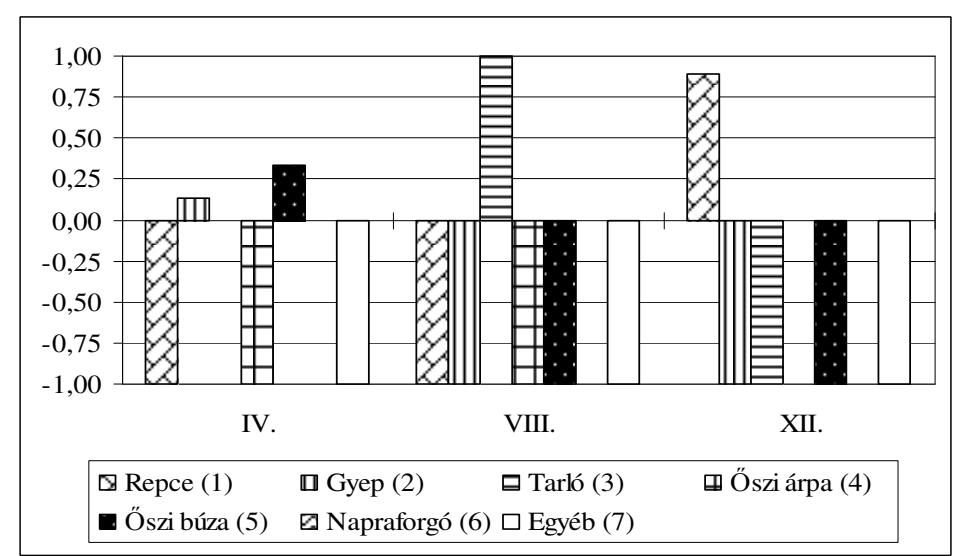

\section{7. ábra: A túzok élőhelyválasztása (IVLEV-index) a Solti-síkon (2005)}

Figure 27: IVLEV's electivity index of Great Bustard in the Solti-plain (2005)

(1) Rape, (2) Grassland, (3) Stubble field, (4) Winter barley, (5) Winter wheat, (6) Sunflower, (7) Other

Az élőhelyválasztási számítások (27. ábra) is alátámasztották a fent leírtakat, miszerint a térségben a túzok a fészkelési időszakban a gyepeket és őszi búzát preferálta. A nyári 
hónapokban elsősorban a tarlókat és gyepeket részesítette elönyben (augusztusban csak tarlókon fordult elő a fajt), míg télen a legkedveltebb tartózkodási helye a repce volt, hasonlóan többi project területhez.

\subsection{A túzok élőhelyhasználata és választása a Solti-síkon 2006-ban}

A Solti-sík monitoring terület 2006-os élőhely kínálata (28. ábra) jól mutatja, hogy - a gyepterületek állandó aránya (31\%) mellett - mindhárom időszak jelentősen különbözik egymástól. A tavaszi szántásokon nyárra elsősorban kukoricát vetettek, jelentős volt a repce vetésterülete és a nyári tarlók részesedése. A tarlók területén azután decemberben szántás, parlag, illetve repce volt található. Utóbbi igen fontos a telelő túzokállomány számára. A faj élőhelyhasználata ezévben is alátámasztotta ezt, az őszi-téli hónapokban a repce adta a látogatott élőhelytípusok 80-90\%-át (29. ábra). A nyári hónapokban emellett kedveltnek bizonyultak a lucernaföldek, tarlók és gyepterületek.

Az élőhelyválasztás (IVLEV-index) adatai alapján elmondhatjuk, hogy tavasszal kizárólag a lucerna, nyáron a tarlók, télen pedig a repce volt prefereált élőhely (30. ábra). A jóminőségü gyepterületek hiánya, valamint az állandó zavarás miatt a madarak gyakran éppen ott tartózkodtak ahol nem jártak traktorok, nem folyt mezőgazdasági munka.

A fentiek alapján a jó minőségü, megfelelően kezelt (védett, legeltetett) gyepterületek elengedhetetlenül fontosak a térség túzokállományának megőrzése szempontjából, elsősorban a tavaszi-nyári hónapokban.

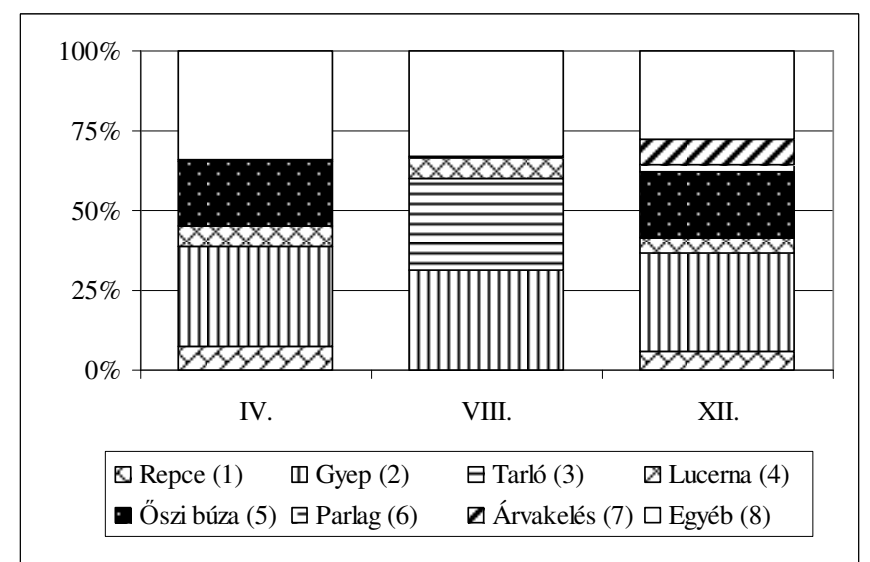

28. ábra: A Solti-sík monitoring terület élőhelykínálata (2006)

Figure 28: Habitat availability in the Solti-plain (2006)

(1) Rape, (2) Grassland, (3) Stubble, (4) Alfalfa, (5) Winter wheat, (6) Fallow,

(7) Volunteer crop, (8) Other;

A költés szempontjából optimális őszi gabonák és gyepek magas aránya kedvező tényező volt, a szántások, repcék, valamint a fészkelésre alkalmatlan nádasok magas aránya viszont jelentősen csökkentette az élettér minőségét, amely összesítve 58,26\%-nyi volt (12. táblázat). Mindezek mellett az árpa korai aratása, a nagy kiterjedésű vegyszerezési munkálatok miatt a térségben gyakorlatilag nem költött a túzok. A fent említett problémák orvoslása elengedhetetlen feltétele a területen élő túzokállomány megóvása érdekében. 


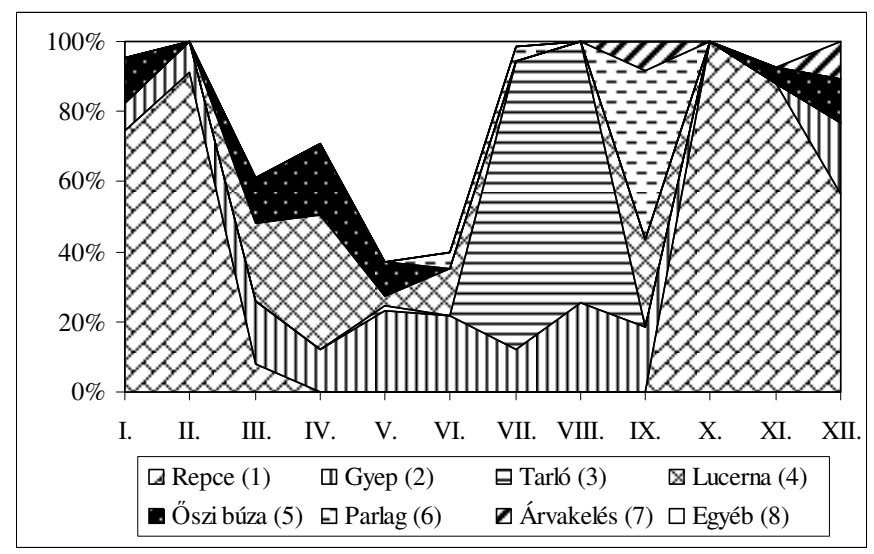

29. ábra: A túzok élőhelyhasználata a Solti-síkon (2006)

Figure 29: Habitat use of the Great Bustard in the Solti-plain (2006)

(1) Rape, (2) Grassland, (3) Stubble, (4) Alfalfa, (5) Winter wheat, (6) Fallow, (7) Volunteer crop, (8) Other

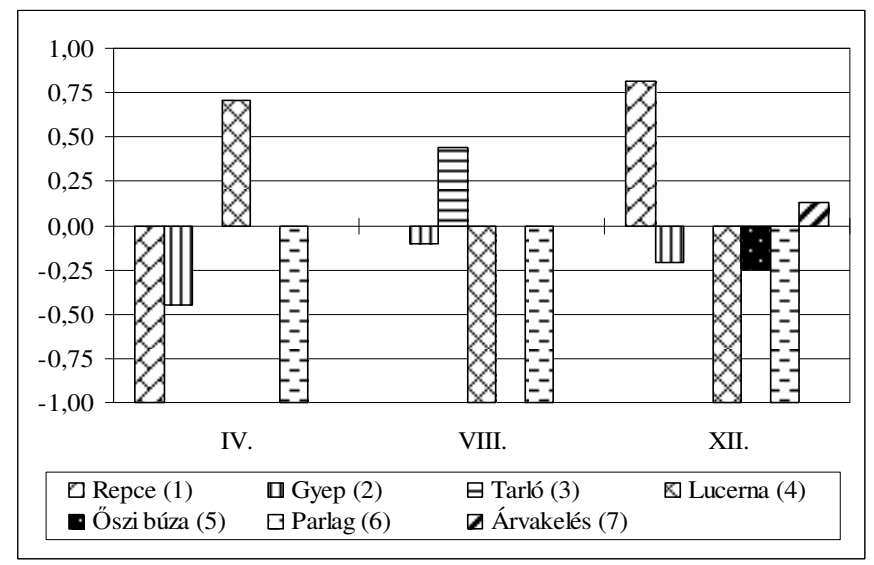

30. ábra: A túzok élőhelyválasztása (IVLEV index) a Solti-síkon (2006)

Figure 30: IVLEV's electivity index of Great Bustard in the Solti-plain (2006)

(1) Rape, (2) Grassland, (3) Stubble, (4) Alfalfa, (5) Winter wheat, (6) Fallow, (7) Volunteer crop

12. táblázat: A Solti-sík élőhelyeinek minősítése tavasszal (2006)

Table 12: Qualification of habitats of the Solti-plain in spring (2006)

\begin{tabular}{|l|c|c|c|}
\hline \multicolumn{1}{|c|}{ Élöhely / Habitat } & $\begin{array}{c}\text { Terület } \\
\text { /Area \% }\end{array}$ & $\begin{array}{c}\text { Kategória } \\
\text { /Category }\end{array}$ & $\begin{array}{c}\text { Red. terület } \\
\text { /Red.area \% }\end{array}$ \\
\hline Gyep / grassland & 31,22 & 5 & $31,21 \%$ \\
\hline Öszi búza / winter wheat & 20,28 & 5 & $20,27 \%$ \\
\hline Szántás / ploughed field & 18,62 & 1 & $0 \%$ \\
\hline Nádszegély / reed belt & 13,83 & 1 & $0 \%$ \\
\hline Repce / rape & 7,38 & 4 & $5,53 \%$ \\
\hline Lucerna / alfalfa & 6,53 & 1 & $0 \%$ \\
\hline Öszi árpa / winter barley & 1,22 & 5 & $1,22 \%$ \\
\hline Egyéb / other & 0,92 & 1 & $0 \%$ \\
\hline Összesen / Total & $\mathbf{1 0 0 , 0 0 \%}$ & & $\mathbf{5 8 , 2 6 \%}$ \\
\hline
\end{tabular}




\subsection{A túzok élőhelyhasználata és választása a Solti-síkon 2007-ben}

A Solti-síkon az egyes kultúrák biztosította élőhelykínálatban a legnagyobb arányban (31\%) a gyepeket találhattuk a monitoring területen, amelyek mindhárom vizsgált időszakban hasonló arányban fordult elő. Az áprilisi felvétel időpontjában a madarak kedvelt téli tartózkodóhelyéül szolgáló repcetáblák több mint 10\%-ot fedték a területnek, majd a nyári (augusztusi) térképezés idején helyét árvakelések, szántások váltották fel. A téli időszakban a repce aránya $3,7 \%$ volt (30. ábra).

A túzok legtöbbet használt élőhelyei a gyepek és a repcetáblák voltak. Emellett a lucerna, őszi búza, árvakelés és tarlók használata volt jelentős (31. ábra). Az élőhelyválasztási értékek (32. ábra) a tavaszi időszakban a lucerna és őszi búza preferenciáját igazolták. Nyáron - változatosabb képet mutatva - a gyepek, az árvakelések és a lucernák választása volt pozitív. A téli időszak nem okozott meglepetést, ezúttal is a repce bizonyult az egyetlen választott kultúrának.

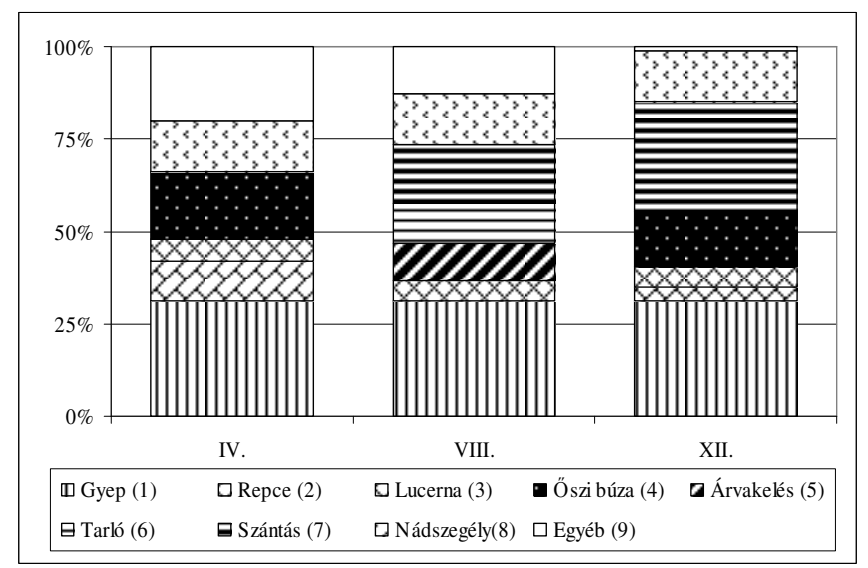

30. ábra: A Solti-síki monitoring terület élőhelykínálata (2007)

Figure 30: Habitat availability in the Solti-plain (2007)

(1) Grassland, (2) Rape, (3) Alfalfa, (4) Winter wheat, (5) Volunteer-crop, (6) Stubble, (7) Ploughed field; (8) Reed belt, (9) Other

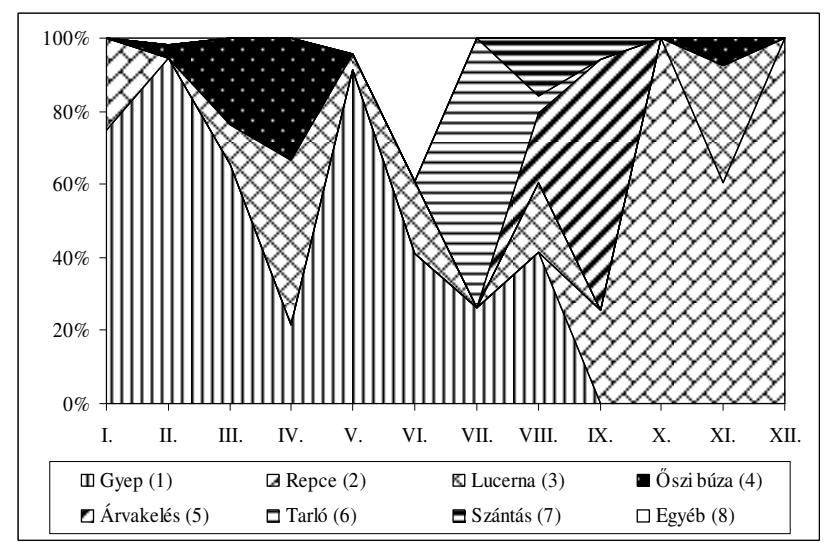

31. ábra: A túzok élőhelyhasználata a Solti-síkon (2007)

Figure 31: Habitat use of the Great Bustard in Solti-sík (2007)

(1) Grassland, (2) Rape, (3) Alfalfa, (4) Winter wheat, (5) Volunteer-crop, (6) Stubble, (7) Ploughed field; (8) Other 


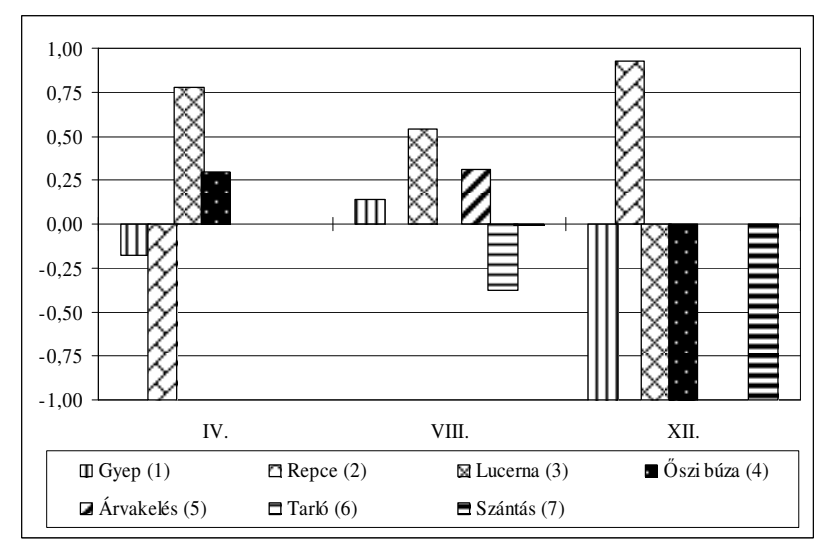

\section{2. ábra: A túzok élőhelyválasztása (IVLEV index) a Solti-síkon (2007)}

Figure 32: IVLEV's electivity index of Great Bustard in the Solti-plain (2007)

(1) Grassland, (2) Rape, (3) Alfalfa, (4) Winter wheat, (5) Volunteer-crop, (6) Stubble, (7) Ploughed field;

A terület tavaszi élőhelymegoszlása alapján végzett minősítés a korábbi éveknél magasabb értéket $(68,94 \%)$ mutatott. Ez elsősorban az 5-ös kategóriába sorolt gyepek, búzatáblák és parlagterületek magas arányának, valamint a 4-es kategóriában szereplő repce $10 \%$ feletti arányának volt köszönhető (13. táblázat).

13. táblázat: A Solti-sík élőhelyeinek minősítése tavasszal (2007)

Table 13: Qualification of habitats of the Solti-plain in spring (2007)

\begin{tabular}{|l|c|c|c|}
\hline \multicolumn{1}{|c|}{ Élöhely / Habitat } & $\begin{array}{c}\text { Terület / } \\
\text { Area \% }\end{array}$ & $\begin{array}{c}\text { Kategória } \\
\text { /Category }\end{array}$ & $\begin{array}{c}\text { Red. terület } \\
\text { /Red.area \% }\end{array}$ \\
\hline Gyep/grassland & $31,22 \%$ & 5 & $31,22 \%$ \\
\hline Öszi búza/winter wheat & $18,20 \%$ & 5 & $18,20 \%$ \\
\hline Parlag/fallow & $1,60 \%$ & 5 & $1,60 \%$ \\
\hline Nádszegély/reed belt & $13,83 \%$ & 1 & $0,00 \%$ \\
\hline Repce/rape & $10,90 \%$ & 4 & $8,18 \%$ \\
\hline Lucerna/alfalfa & $5,71 \%$ & 1 & $0,00 \%$ \\
\hline Őszi árpa/winter barley & $1,22 \%$ & 5 & $1,22 \%$ \\
\hline Kukorica/maize & $10,79 \%$ & 3 & $5,40 \%$ \\
\hline Napraforgó/sunflower & $6,25 \%$ & 3 & $3,13 \%$ \\
\hline Egyéb/other & $6,53 \%$ & 1 & $0,00 \%$ \\
\hline Összesen / Total & $\mathbf{1 0 0 , 0 0 \%}$ & & $\mathbf{6 8 , 9 4 \%}$ \\
\hline
\end{tabular}

\subsection{A túzok élőhelyhasználata és választása a Solti-síkon 2008-ban}

2008-ban a tavaszi élőhelytérképezés alapján a nagy kiterjedésü gyepek mellett, mozaikos mezőgazdasági kultúrák alkották a területet, annak északi oldalán a jellegzetes nádszegéllyel. Az egyes kultúrák százalékban kifejezett összesített aránya ismeretében (33. ábra) a gyepek összes borítása meghaladta a 30\%-ot. Emellett az őszi búza, a napraforgó és a kukorica voltak a legnagyobb területeken ültetett kultúrák.

A túzok élőhelyhasználatára január-február hónapban a repce, az év későbbi időszakában a gyepek használata volt a legjellemzőbb (34. ábra). Emellett mind a 6 vizsgált hónapban megfigyelhetőek voltak a madarak őszi búzában. 


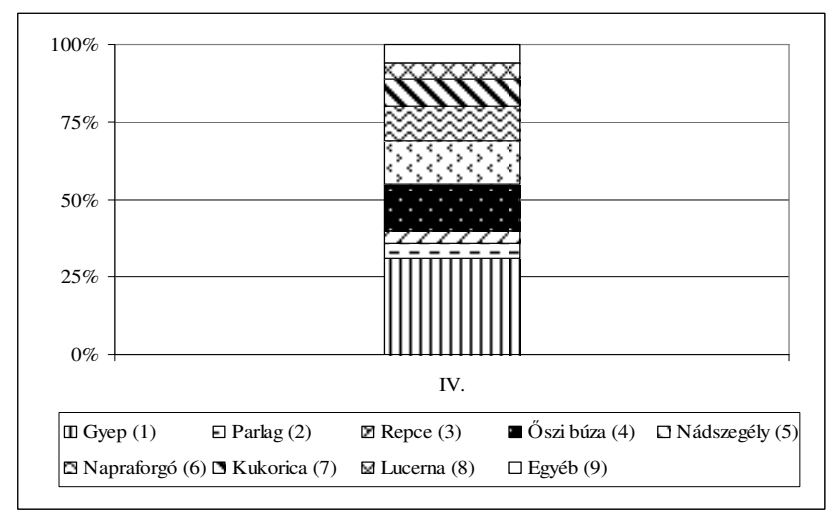

33. ábra: A Solti-síki monitoring terület élőhelykínálata (2008)

Figure 33: Habitat availability in the Solti-plain (2008)

(1) Grasslan, (2) Fallow, (3) Rape (4) Winter wheat, (5) Reed belt, (6) Sunflower, (7) Maize, (8) Alfalfa, (9) Other;

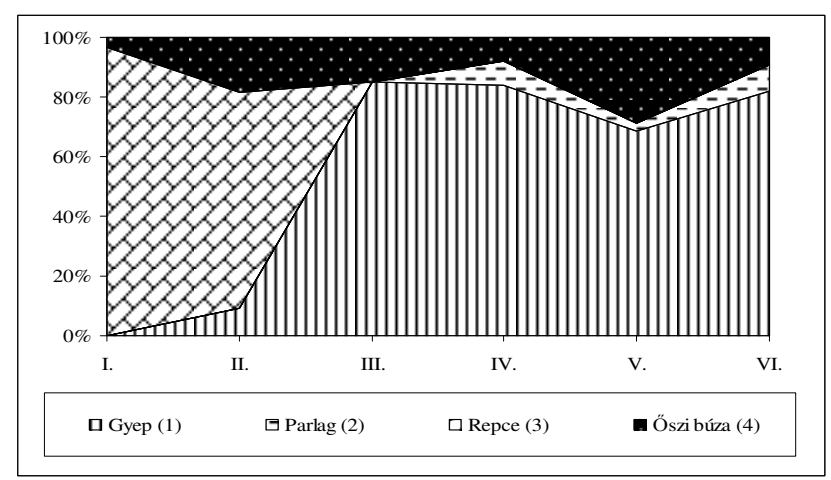

\section{4. ábra: A túzok élőhelyhasználata a Solti-síkon (2008)}

Figure 34: Habitat use of the Great Bustard in the Solti-plain (2008)

(1) Grassland, (2) Fallow, (3) Rape, (4) Winter wheat;

Az élőhely-preferencia (IVLEV-index) számításokat április hónapra vonatkozóan végeztük el, hiszen ez a hónap volt az élőhely térképezés időpontja. Ebben a hónapban a gyepek és a parlagterületek bizonyultak kedvelt élőhelynek (35. ábra).

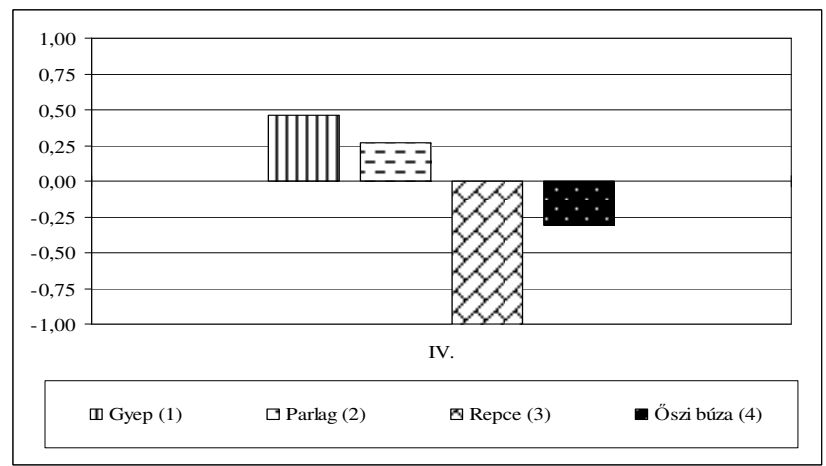

35. ábra: A túzok élőhelyválasztása (IVLEV index) a Solti-síkon (2008)

Figure 35: IVLEV's electivity index of Great Bustard in the Solti-plain (2008)

(1) Grassland, (2) Fallow, (3) Rape, (4) Winter wheat 
A tavaszi élőhelytérképezés alapján elvégzett élöhelyminősítés 66\%-os értéket adott. Ez közel azonos volt a 2007-es év eredményével. Az öszi búza és a repce arányának csökkenése azonban néhány százalékos visszaesést eredményezett a 2008-as mértéknél (14. táblázat).

14. táblázat: A Solti-sík élőhelyeinek minősítése tavasszal (2008)

Table 14: Qualification of habitats of the Solti-plain in spring (2008)

\begin{tabular}{|l|c|c|c|}
\hline \multicolumn{1}{|c|}{ Élöhely / Habitat } & $\begin{array}{c}\text { Terület } \\
\text { /Area \% }\end{array}$ & $\begin{array}{c}\text { Kategória } \\
\text { /Category }\end{array}$ & $\begin{array}{c}\text { Red. terület } \\
\text { /Red.area \% }\end{array}$ \\
\hline Gyep/grassland & $31,22 \%$ & 5 & $31,22 \%$ \\
\hline Öszi búza/winter wheat & $15,10 \%$ & 5 & $15,10 \%$ \\
\hline Öszi árpa/winter barley & $2,15 \%$ & 5 & $2,15 \%$ \\
\hline Nádszegély/reed belt & $13,83 \%$ & 1 & $0,00 \%$ \\
\hline Repce/rape & $4,19 \%$ & 4 & $3,14 \%$ \\
\hline Lucerna/alfalfa & $5,48 \%$ & 1 & $0,00 \%$ \\
\hline Ugar/set-aside & $4,57 \%$ & 5 & $4,57 \%$ \\
\hline Kukorica/maize & $8,76 \%$ & 3 & $4,38 \%$ \\
\hline Napraforgó/sunflower & $11,02 \%$ & 3 & $5,51 \%$ \\
\hline Egyéb/other & $3,68 \%$ & 1 & $0,00 \%$ \\
\hline Összesen / Total & $\mathbf{1 0 0 , 0 0 \%}$ & & $\mathbf{6 6 , 0 7 \%}$ \\
\hline
\end{tabular}

\section{HEVESI-SÍK}

\subsection{A túzok élőhelyhasználata és választása a Hevesi-síkon 2005-ben}

A Hevesi-sík élőhelykínálatát a tavaszi, illetve a téli időszakban a füves élőhelyek, illetve az őszi búza uralták, míg a nyári periódusban utóbbi helyét tarlók vették át, a teljes mintaterület $42 \%$-át adva (36. ábra).

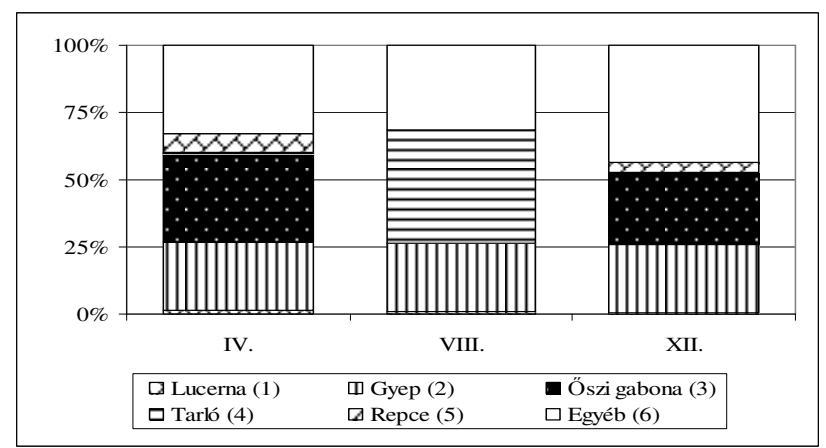

36. ábra: A Hevesi-sík élőhelykínálata (2005)

Figure 36: Habitat availability of the Hevesi-plain (2005)

(1) Alfalfa, (2) Grassland, (3) Winter wheat, (4) Stubble, (5) Rape, (6) Other

A túzok élőhelyhasználatát (37. ábra) szemügyre véve megállapíthatjuk, hogy a Hevesi-síkon elsősorban a gyep, lucerna, őszi búza, illetve repce élőhelyeket részesítették előnyben.

Az élőhely-preferenciát kifejező IVLEV-indexek (38. ábra) is rámutattak arra, hogy a tavaszi időszakban (illetve a fészkelésnél) elsősorban a magasabb takarást biztosító őszi búza és repce volt preferált tartózkodási helye a madaraknak. A nyári hónapokban a lucerna és a gyepek, míg télen nagy fölénnyel a repce választása dominált. A fészkelési időszakban a Hevesi-sík élőhely minősége igen magas, 73,35\%-os volt, köszönhetően elsősorban a gyepek, az őszi búza és a repce magas arányának (15. táblázat). 


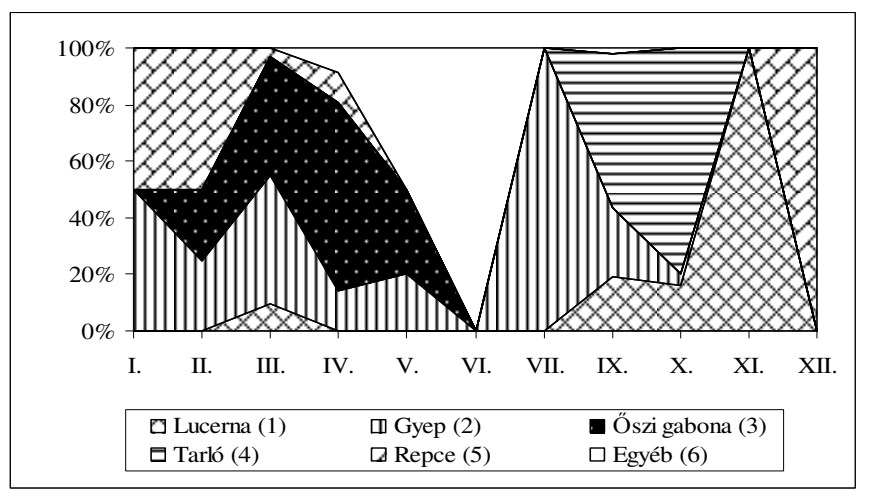

37. ábra: A túzok élőhelyhasználata a Hevesi-síkon (2005)

Figure 37: Habitat use of the Great Bustard of the Hevesi-plain (2005)

(1) Alfalfa, (2) Grassland, (3) Winter wheat, (4) Stubble, (5) Rape, (6) Other

15. táblázat: A Hevesi-sík élőhelyeinek minősítése tavasszal (2005)

Table 15: Qualification of habitats of the Hevesi-plain in spring (2005)

\begin{tabular}{|l|c|c|c|}
\hline \multicolumn{1}{|c|}{ Élöhely / Habitat } & $\begin{array}{c}\text { Terület } \\
\text { /Area \% }\end{array}$ & $\begin{array}{c}\text { Kategória } \\
\text { /Category }\end{array}$ & $\begin{array}{c}\text { Red. terület } \\
\text { /Red.area \% }\end{array}$ \\
\hline Cukorrépa/sugar beet & $0,26 \%$ & 2 & $0,07 \%$ \\
\hline Erdö/forest & $0,77 \%$ & 1 & $0,00 \%$ \\
\hline Gyep/grassland & $25,61 \%$ & 5 & $25,61 \%$ \\
\hline Lucerna/alfalfa & $1,45 \%$ & 1 & $0,00 \%$ \\
\hline Mák/poppy & $0,07 \%$ & 1 & $0,00 \%$ \\
\hline Mocsár/marsh & $0,67 \%$ & 1 & $0,00 \%$ \\
\hline Napraforgó/sunflower & $0,85 \%$ & 3 & $0,42 \%$ \\
\hline Öszi árpa/winter barley & $1,19 \%$ & 5 & $1,19 \%$ \\
\hline Öszi búza/winter wheat & $31,62 \%$ & 5 & $31,62 \%$ \\
\hline Repce/rape & $6,76 \%$ & 4 & $5,07 \%$ \\
\hline Szántó/ploughed field & $20,43 \%$ & 1 & $0,00 \%$ \\
\hline Tarló/stubble & $0,28 \%$ & 1 & $0,00 \%$ \\
\hline Tavaszi árpa/spring barley & $3,11 \%$ & 5 & $3,11 \%$ \\
\hline Tavaszi búza/spring wheat & $0,43 \%$ & 5 & $0,43 \%$ \\
\hline Ugar/fallow & $5,84 \%$ & 5 & $5,84 \%$ \\
\hline Egyéb/other & $0,67 \%$ & 1 & $0,00 \%$ \\
\hline Összesen / Total & $\mathbf{1 0 0 , 0 0 \%}$ & \multicolumn{2}{|c|}{} \\
\hline
\end{tabular}

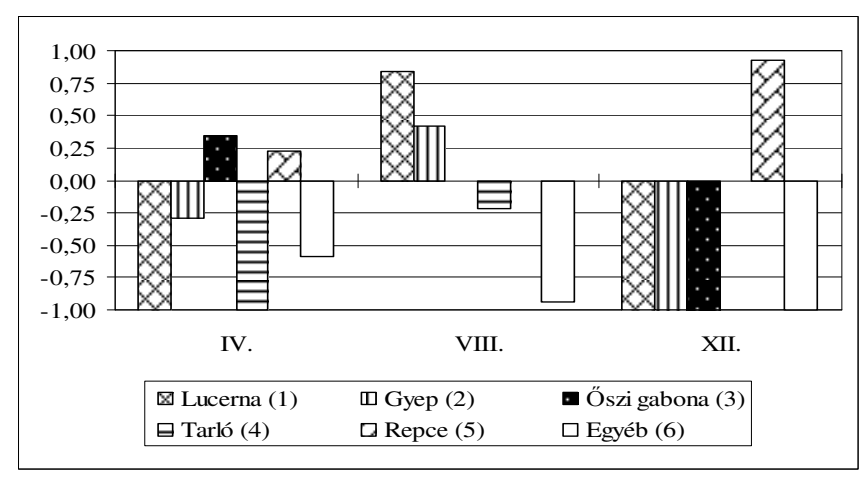

38. ábra: A túzok élőhelyválasztása (IVLEV-index) a Hevesi-síkon (2005)

Figure 38: IVLEV's electivity index of Great Bustard in the Hevesi-plain (2005)

(1) Alfalfa, (2) Grassland, (3) Winter wheat, (4) Stubble, (5) Rape, (6) Other 


\subsection{A túzok élőhelyhasználata és választása a Hevesi-síkon 2006-ban}

A Hevesi-sík mintaterületen a gyepek mindhárom felvételezési időszakban kb. 25\%-át jelentette az élőhelyeknek (39. ábra). Tavasszal és télen az őszi búza adta a terület másik $25 \%$-át, nyáron a tarlók foglalták el a terület nagy részét, amelyet a túzokok szinte egyáltalán nem használták (40. ábra).

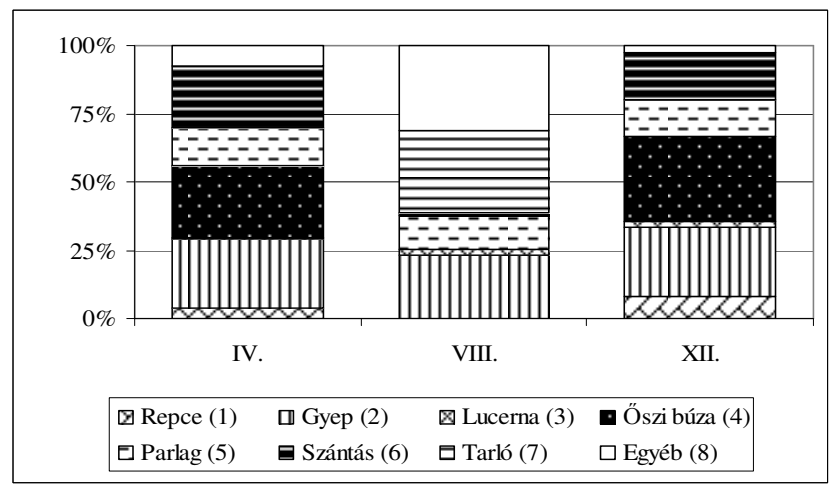

\section{9. ábra: A Hevesi-síki monitoring terület élőhelykínálata (2006)}

Figure 39: Habitat availability in the Hevesi-plain (2006)

(1) Rape, (2) Grassland, (3) Alfalfa, (4) Winter wheat, (5) Fallow, (6) Ploughed field, (7) Stubble, (8) Other

Az élőhelykezelések, amelyek ugaroltatásból, repcevetésből, kalászosok vetéséből, lucernatelepítésből álltak, láthatóan sikeresnek bizonyultak. Az év utolsó negyedében a madarakat szinte már csak az élőhelykezelésbe bevont szántókon, illetve azok közvetlen környezetében lehetett megtalálni. Ezeknek a területeknek az ember általi zavarása csökkent, valamint feltehetően a predátorok létszáma is alacsonyabb volt.

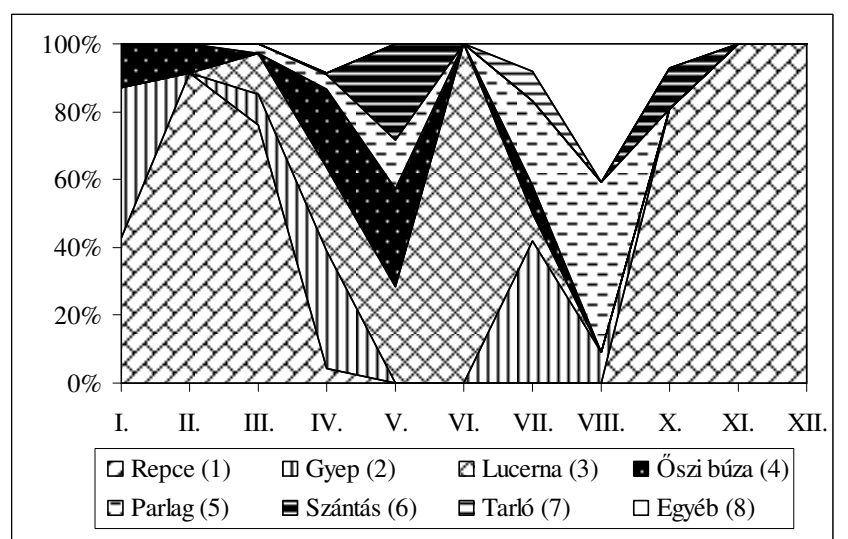

\section{0. ábra: A túzok élőhelyhasználata a Hevesi-síkon (2006)}

Figure 40: Habitat use of the Great Bustard in the Hevesi-plain (2006)

(1) Rape, (2) Grassland, (3) Alfalfa, (4) Winter wheat, (5) Fallow, (6) Ploughed field, (7) Stubble, (8) Other;

A túzokok az év első két hónapjában elsősorban a dormándi Nagy-Hanyi-puszta térségében fordultak elő repcetáblákon, a dürgés idején pedig nagyrészt Sarud közelében voltak megtalálhatók. Ugyanitt lehetett megfigyelni a madarakat az őszi-téli időszakban is, amikor a legtöbb időt a túzokvédelmi magterület LIFE-projekt pénzforrásból vásárolt és művelt szántóterületein és azok közelében töltötték. 
Az IVLEV-index értékei alapján (41. ábra) áprilisban a repce, gyep és lucerna bizonyult preferált habitatnak, a nyári hónapokban a parlagterületek, télen pedig ismételten a repcetáblák választása mutatkozott meg.

A monitoring területen, a fészkelési időszakban történt élőhelyminősítés ezúttal már diferenciáltan vette figyelembe a különbözőképpen kezelt élőhelyeket. Így megkülönböztettünk 3, 4, és 5-ös bonítású gyepeket, valamint 4-es és 5-ös bonitású öszi búzát. A túzok szempontjából kedvezően (kevésbé intenzíven) kezelt őszi búza 5-ös bonitást kapott, míg az intenzívebben kezelt csak 4-est. A gyepterületek esetében fészkelésre kevésbé alkalmas, birkákkal legeltetett területek 3-as, a zavart gyepek 4-es, míg a zavartalan gyepek 5ös értékkel kerültek beszámításra. Az eredmény 65,06\%-os értéket mutatott (16. táblázat), amely jónak nevezhető, és elsősorban a megfelelően kezelt őszi búza, gyep és ugar viszonylag magas arányának volt köszönhető.

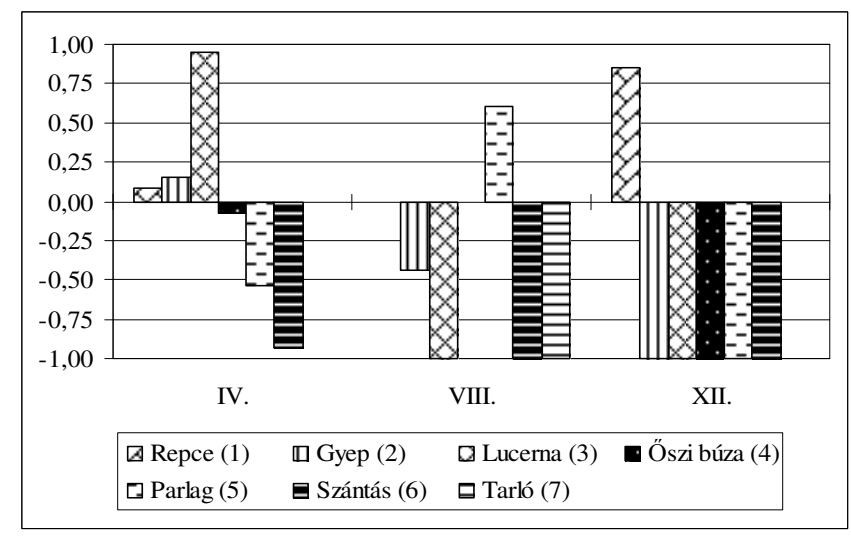

41. ábra: A túzok élőhelyválasztása (IVLEV-index) a Hevesi-síkon (2006)

Figure 41: IVLEV's electivity index of Great Bustard in the Hevesi-plain (2006)

(1) Rape, (2) Grassland, (3) Alfalfa, (4) Winter wheat, (5) Fallow, (6) Ploughed field, (7) Stubble

16. táblázat: A Hevesi-sík élőhelyeinek minősítése tavasszal (2006)

Table 16: Qualification of habitats of the Hevesi-plain in spring (2006)

\begin{tabular}{|l|r|c|c|}
\hline \multicolumn{1}{|c|}{ Élőhely / Habitat } & $\begin{array}{r}\text { Terület } \\
\text { /Area \% }\end{array}$ & $\begin{array}{c}\text { Kategória } \\
\text { /Category }\end{array}$ & $\begin{array}{c}\text { Red. terület } \\
\text { /Red.area \% }\end{array}$ \\
\hline Öszi búza (C: 4) / winter wheat & $9,18 \%$ & 4 & $6,89 \%$ \\
\hline Öszi búza (C: 5) / winter wheat & $17,30 \%$ & 5 & $17,30 \%$ \\
\hline Gyep (C: 3) / winter wheat & $3,72 \%$ & 3 & $1,86 \%$ \\
\hline Gyep (C: 4) / grassland & $7,62 \%$ & 4 & $5,72 \%$ \\
\hline Gyep (C: 5) / grassland & $14,02 \%$ & 5 & $14,02 \%$ \\
\hline Szántás / ploughed field & $22,48 \%$ & 1 & $0,00 \%$ \\
\hline Ugar / fallow & $13,94 \%$ & 5 & $13,94 \%$ \\
\hline Napraforgó / sunflower & $5,31 \%$ & 3 & $2,65 \%$ \\
\hline Repce / rape & $3,57 \%$ & 4 & $2,68 \%$ \\
\hline Egyéb / other & 2,86 & 1 & $0,00 \%$ \\
\hline Összesen / Total & $\mathbf{1 0 0 , 0 0 \%}$ & & $\mathbf{6 5 , 0 6 \%}$ \\
\hline
\end{tabular}

\subsection{A túzok élőhelyhasználata és választása a Hevesi-síkon 2007-ben}

A Hevesi-sík monitoring területe a túzokok által leginkább használt része a kijelölt programterületnek, egyre-inkább erre a területre koncentrálódik a hevesi túzokállomány. Jól megfigyelhető volt a gyepterületek állandó (25\% körüli) aránya, amely a túzokok kedvelt 
tartózkodási helye volt. Emellett áprilisban és decemberben az őszi búza aránya ért el 30\% körüli értéket. A nyári időszakban e területek nagy részén tarlókat találhattunk (42. ábra).

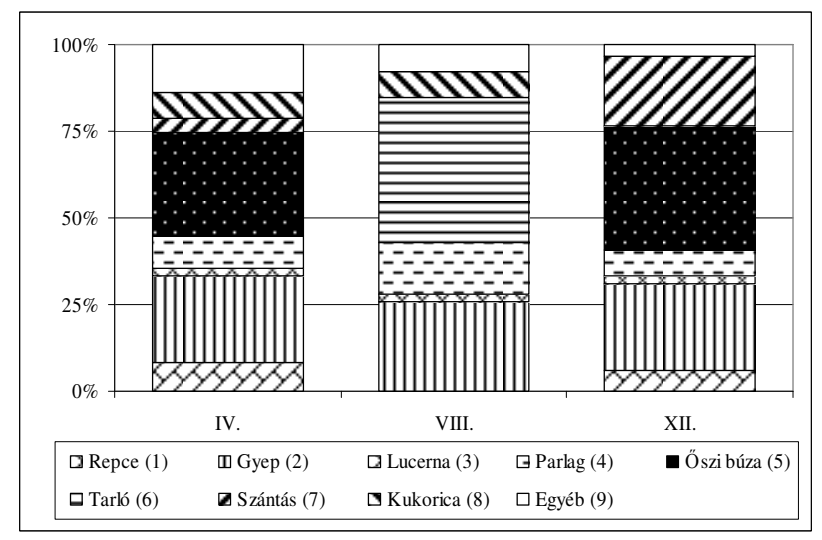

42. ábra: A Hevesi-síki monitoring terület élőhelykínálata (2007)

Figure 42: Habitat availability in the Hevesi-plain (2007)

(1) Rape, (2) (Grassland, (3) Alfalfa, (4) Fallow, (5) Winter wheat,

(6) Stubble, (7) Ploughed field, (8) Maize, (9) Other

A túzok élőhelyhasználatát az év során a repce, lucerna, gyepterületek valamint a nyár derekán a parlagterületek használata jellemezte (43. ábra).

Az élőhelykínálattal összevetve az élőhelyhasználati adatokat, megkapjuk a túzok élőhelyválasztását (IVLEV-index) a Hevesi-síkon (44. ábra). Mivel augusztus hónapban nem fordult elő túzok a monitoring területen, így preferencia vizsgálatot erre az időszakra nem végezhettünk.

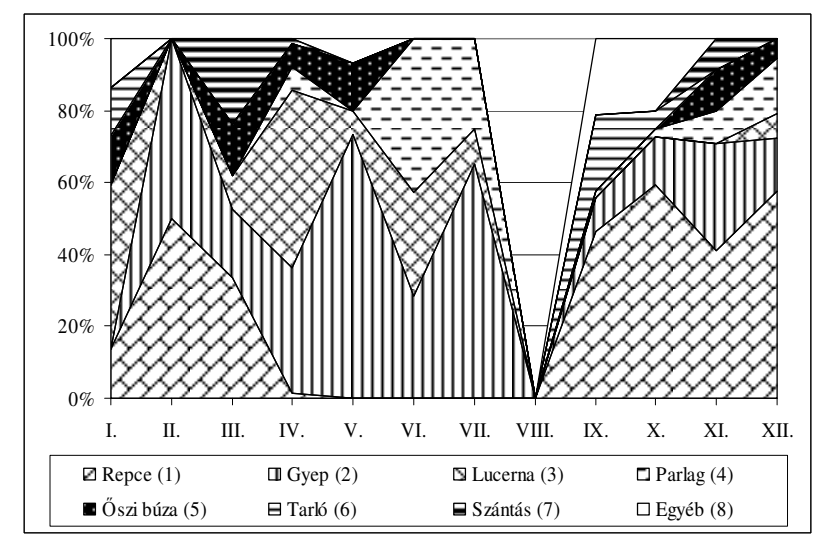

43. ábra: A túzok élőhelyhasználata a Hevesi-síkon (2007)

Figure 43: Habitat use of the Great Bustard in the Hevesi-plain (2007)

(1) Rape, (2) (Grassland, (3) Alfalfa, (4) Fallow, (5) Winter wheat,

(6) Stubble, (7) Ploughed field, (9) Other;

Áprilisban a lucernatáblák és a gyepek bizonyultak preferált élőhelyeknek. A téli hónapban a repce egyértelmű választása mellett - szintén a lucernák, valamint a parlagok választása volt pozitív.

A területnek a fészkelési időszakban elvégzett minősítése 83,95\%-os, kifejezetten magasnak mondható értéket adott (17. táblázat). Ennek elsődleges oka az 5-ös kategóriába sorolható természetes gyepek mellett a szintén legmagasabban értékelt őszi búzák magas részaránya volt a területen. 


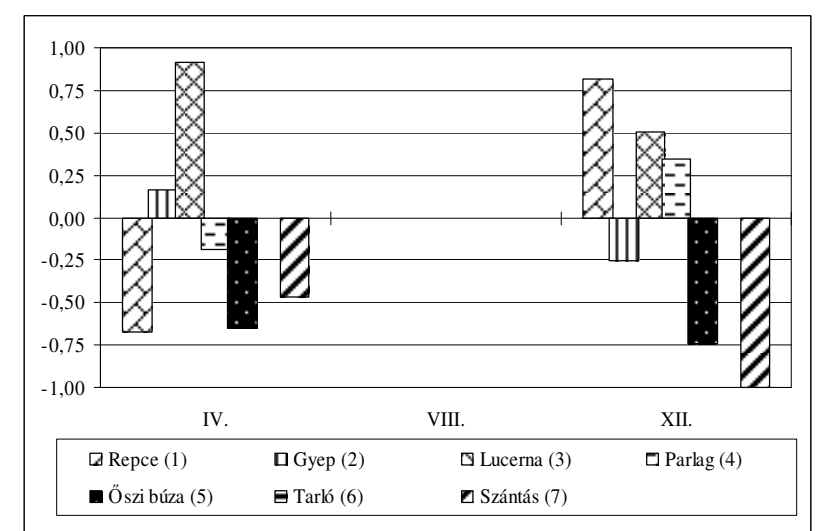

44. ábra: A túzok élőhelyválasztása (IVLEV index) a Hevesi-síkon (2007)

Figure 44: IVLEV's electivity index of Great Bustard in the Hevesi-plain (2007)

(1) Rape, (2) (Grassland, (3) Alfalfa, (4) Fallow, (5) Winter wheat,

(6) Stubble, (7) Ploughed field;

17. táblázat: A Hevesi-sík élőhelyeinek minősítése tavasszal (2007)

Table 17: Qualification of habitats of the Hevesi-plain in spring (2007)

\begin{tabular}{|l|c|c|c|}
\hline \multicolumn{1}{|c|}{ Élöhely / Habitat } & $\begin{array}{c}\text { Terület } \\
\text { /Area \% }\end{array}$ & $\begin{array}{c}\text { Kategória } \\
\text { /Category }\end{array}$ & $\begin{array}{c}\text { Red. terïlet } \\
\text { /Red.area \% }\end{array}$ \\
\hline Öszi búza/winter wheat & $29,96 \%$ & 5 & $29,96 \%$ \\
\hline Gyep/grassland & $25,21 \%$ & 5 & $25,21 \%$ \\
\hline Kukorica/maize & $7,47 \%$ & 3 & $3,74 \%$ \\
\hline Ugar/set-aside & $15,64 \%$ & 5 & $15,64 \%$ \\
\hline Napraforgó/sunflower & $4,21 \%$ & 3 & $2,11 \%$ \\
\hline Repce/rape & $8,13 \%$ & 4 & $6,10 \%$ \\
\hline Zab/oat & $1,20 \%$ & 5 & $1,20 \%$ \\
\hline Egyéb/other & $8,18 \%$ & 1 & $0,00 \%$ \\
\hline Összesen / Total & $100,00 \%$ & & $\mathbf{8 3 , 9 5 \%}$ \\
\hline
\end{tabular}

\subsection{A túzok élőhelyhasználata és választása a Hevesi-síkon 2008-ban}

Hasonlóan a 2007-es tavaszi állapotokhoz, a 2008-as évben is az öszi gabonák és a gyepek túlsúlya jellemezte tavasszal a Hevesi-sík monitoring területét. Emellett 19\% szántás, 8\% ugar és $5 \%$ repce foglalta el az életteret (45. ábra).

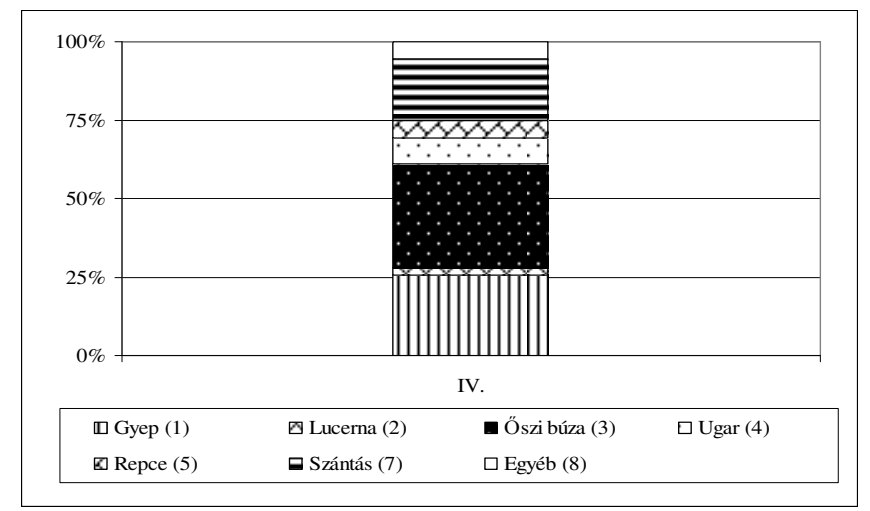

45. ábra: A Hevesi-síki monitoring terület élőhelykínálata (2008)

Figure 45: Habitat availability in the Hevesi-plain (2008)

(1) Rape, (2) Alfalfa, (3) Grassland, (4) Fallow, (5) Volunteer crop,

(6) Winter wheat, (7) Ploughed field, (8) Stubble, (9) Other 


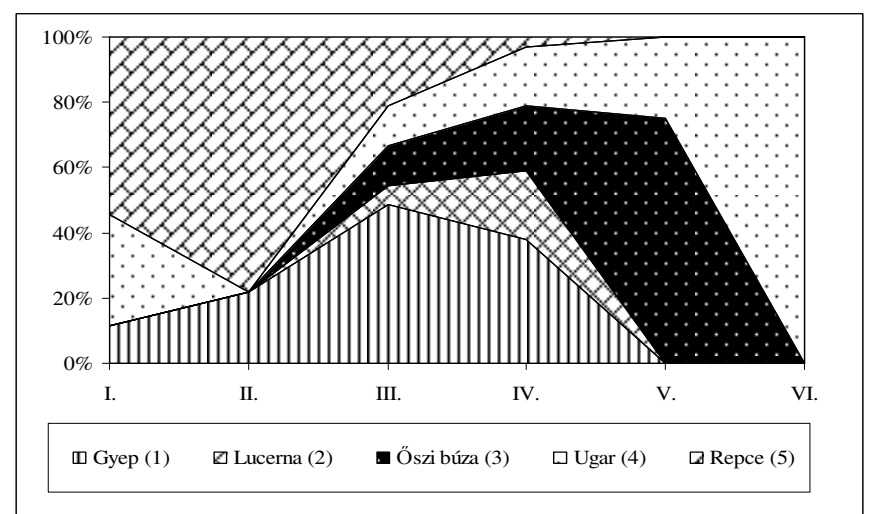

46. ábra: A túzok élőhelyhasználata a Hevesi-síkon (2008)

Figure 46: Habitat use of the Great Bustard in the Hevesi-plain (2008)

(1) Rape, (2) Alfalfa, (3) Grassland, (4) Fallow, (5) Volunteer crop,

(6) Winter wheat, (7) Ploughed field, (8) Stubble, (9) Other

A túzok a vizsgált hat hónap során változatos képet mutatott az élőhelyek használatát illetően. Az év első két téli hónapjában a repce volt a legtöbbet használt élőhely, míg márciustól egyre nagyobb szerepet kaptak az őszi búza és a lucernatáblák, valamint a gyepek. Júniusban kizárólag ugaron tartózkodtak a túzokok (46. ábra).

A IVLEV-indexek április hónapban a lucerna, az ugar és a gyepek preferenciáját mutatták (47. ábra).

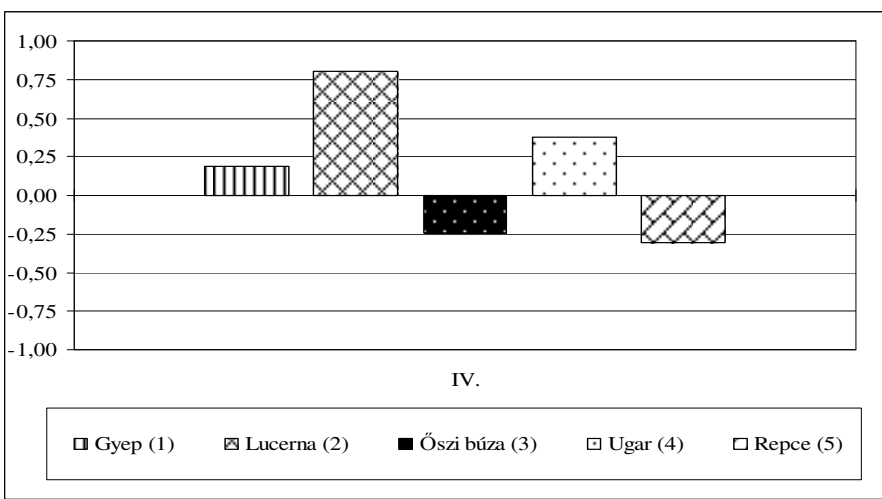

47. ábra: A túzok élőhelyválasztása (IVLEV-index) a Hevesi-síkon (2008)

Figure 47: IVLEV's electivity index of Great Bustard in the Hevesi-plain (2008)

(1) Rape, (2) Alfalfa, (3) Grassland, (4) Fallow, (5) Volunteer crop,

(6) Winter wheat, (7) Ploughed field, (8) Stubble

18. táblázat: A Hevesi-sík élőhelyeinek minősítése tavasszal (2008)

Table 18: Qualification of habitats of the Hevesi-plain in spring (2008)

\begin{tabular}{|l|c|c|c|}
\hline \multicolumn{1}{|c|}{ Élőhely / Habitat } & $\begin{array}{c}\text { Terület } \\
\text { /Area \% }\end{array}$ & $\begin{array}{c}\text { Kategória } \\
\text { /Category }\end{array}$ & $\begin{array}{c}\text { Red. terület } \\
\text { /Red.area \% }\end{array}$ \\
\hline Öszi búza/winter wheat & $33,14 \%$ & 5 & $33,14 \%$ \\
\hline Gyep/grassland & $25,71 \%$ & 5 & $25,71 \%$ \\
\hline Szántás/ploughed field & $19,36 \%$ & 1 & $0,00 \%$ \\
\hline Ugar/set-aside & $8,18 \%$ & 5 & $8,18 \%$ \\
\hline Lucerna/alfalfa & $2,31 \%$ & 1 & $0,00 \%$ \\
\hline Repce/rape & $5,64 \%$ & 4 & $4,23 \%$ \\
\hline Tavaszi gabona/spring cereals & $0,93 \%$ & 3 & $0,47 \%$ \\
\hline Egyéb/other & $4,73 \%$ & 1 & $0,00 \%$ \\
\hline Összesen / Total & $\mathbf{1 0 0 , 0 0 \%}$ & & $\mathbf{7 1 , 7 3 \%}$ \\
\hline
\end{tabular}


A monitoring terület minősége, jósága 2008-ban kissé elmaradt az előző év eredményétől. A még mindig magasnak tekinthető 71,73\%-os érték elsősorban az őszi gabonák, a természetes gyepek és ugarok magas arányának volt köszönhető (18. táblázat).

\section{BORSODI-MEZŐSÉG}

\subsection{A túzok élőhelyhasználata a Borsodi-Mezőségben 2005-ben}

A Borsodi-Mezőség mintaterület élőhelykínálatát technikai okok miatt 2005-ben nem tudtuk felvételezni, ezért a terület esetében csak élőhelyhasználati adatok állnak rendelkezésünkre (48. ábra). A túzok élőhelyhasználatáról ez alapján megállapíthatjuk, hogy a területen elsősorban a gyepeket részesített előnyben, az észlel madarak 47\%-át, éves szinten ezen az élőhelytípuson figyeltük meg. Második leginkább használt élőhelynek a repce bizonyult (éves szinten 18\%-al), míg harmadik leglátogatottabb élőhely a lucerna volt (17\%). A további élőhelytípusok közül az őszi búzát elsősorban költési időszakban látogatták a madarak, míg a téli hónapokban kedvelt tartózkodási helyek voltak a területen található szántások.

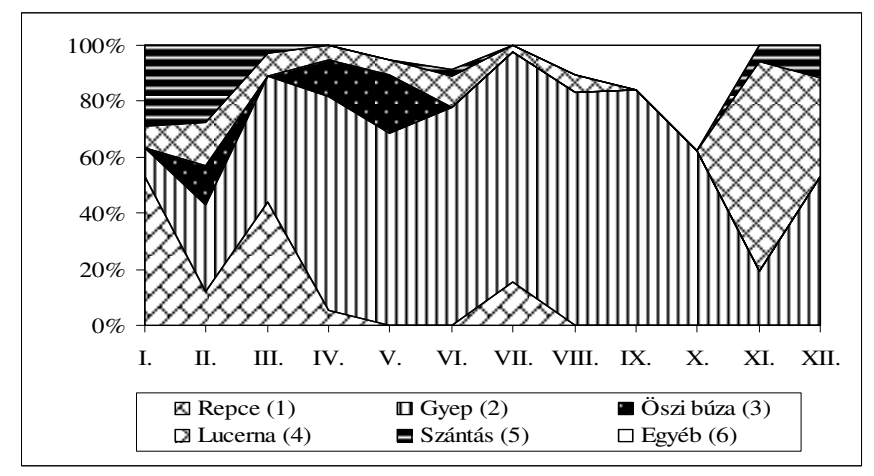

48. ábra: A túzok élőhelyhasználata a Borsodi-Mezőségben (2005)

Figure 48: Habitat use of the Great Bustard of the Borsodi-Mezőség (2005)

(1) Rape, (2) Grassland, (3) Winter wheat, (4) Alfalfa, (5) Ploughed field, (6) Other

\subsection{A túzok élőhelyhasználata és választása a Borsodi-Mezőségben 2006-ban}

A Borsodi-Mezőség monitoring területen a gyepek aránya egész évben 40-50\% körül volt, emellett a tavaszi-téli hónapokban őszi búza, nyáron kukorica és tarlók adták a térség élőhelykínálatát (49. ábra). A téli időszakban a repce terület aránya meghaladta a 10\%-ot.

A túzok élőhelyhasználatára is a gyepterületek túlsúlya volt jellemző a BorsodiMezőségben, főként a nyári, kora őszi hónapokban. Emellett télen a repce és a lucerna bizonyult kedvelt élőhelynek (50. ábra). A lucerna használata 20-30\% körüli értékkel januártól augusztusig állandónak bizonyult, amellett, hogy ez az élőhelynek mindössze 4\%-át foglalta el az említett hónapokban.

Az élőhelyválasztási adatok (IVLEV-index) is ezt támasztják alá: tavasszal és nyáron is preferált élőhelynek bizonyult gyepek, illetve a tavaszi időszakban a lucerna IVLEV-index értéke volt kiemelkedő (51. ábra). Decemberben nem volt túzokészlelés a monitoring területen, így a téli értékelést nem tudtunk végezni. A téli hónapokra a madarak nem álltak be 
állandó telelőhelyre annak ellenére, hogy megfelelő mennyiségben állt rendelkezésre repcevetés.

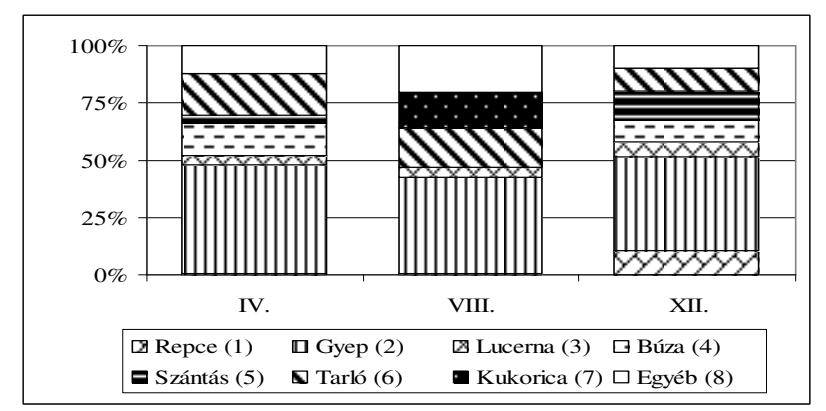

49. ábra: A Borsodi-Mezőség monitoring terület élőhelykínálata (2006)

Figure 49: Habitat availability in the Borsodi-Mezőség (2006)

(1) Rape, (2) Alfalfa, (3) Grassland, (4) Ploughed field, (5) Stubble, (6) Maize, (7) Wheat, (8) Other;

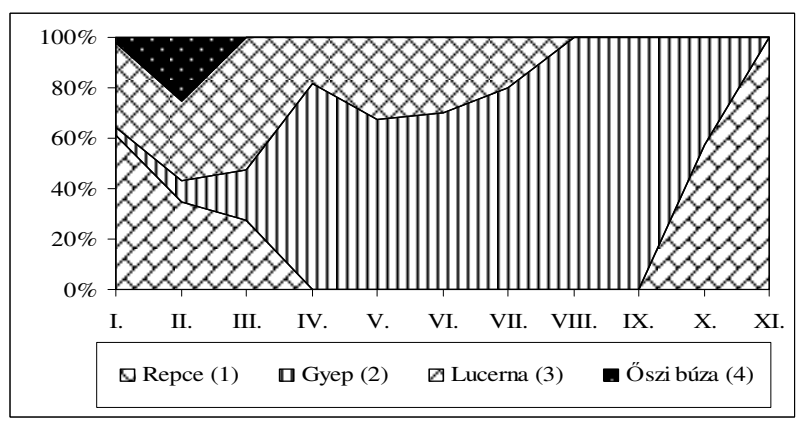

50. ábra: A túzok élőhelyhasználata a Borsodi-Mezőségben (2006)

Figure 50: Habitat use of the Great Bustard in the Borsodi-Mezőség (2006)

(1) Rape, (2) Grassland, (3) Alfalfa (4) Winter wheat;

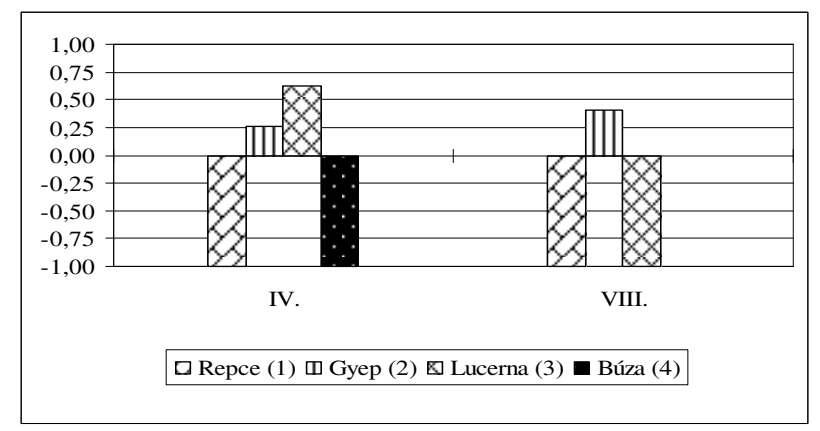

51. ábra: A túzok élőhelyválasztása (IVLEV index) a Borsodi-Mezőségben (2006)

Figure 51: IVLEV's electivity index of Great Bustard in the Borsodi-Mezőség (2006)

(1) Rape, (2) Alfalfa, (3) Grassland, (4) Ploughed field, (5) Stubble, (6) Maize, (7) Wheat

A Borsodi-Mezőség monitoring területének tavaszi bonitálása 62,78\%-os eredményt adott (19. táblázat). Ez a közepesnek mondható eredmény egyfelől utal a fészkelés szempontjából előnyös gyepterületek és kalászosok (búza, árpa) magas arányára, emellett azonban a tarlók és szántások aránya is magas volt, amely jelentősen rontotta az eredményt. 
19. táblázat: A Borsodi-Mezőségi élőhelyeinek minősítése tavasszal (2006)

Table 19: Qualification of habiutats of the Borsodi-Mezőség area in spring (2006)

\begin{tabular}{|l|c|c|c|}
\hline \multicolumn{1}{|c|}{ Élöhely / Habitat } & $\begin{array}{c}\text { Terület } \\
\text { /Area \% }\end{array}$ & $\begin{array}{c}\text { Kategória } \\
\text { /Category }\end{array}$ & $\begin{array}{c}\text { Red. terület } \\
\text { /Red.area \% }\end{array}$ \\
\hline Gyep/grassland & $47,38 \%$ & 5 & $47,38 \%$ \\
\hline Tarló/stubble & $18,34 \%$ & 1 & $0,00 \%$ \\
\hline Öszi búza/winter wheat & $14,16 \%$ & 5 & $14,16 \%$ \\
\hline Lucerna/alfalfa & $4,20 \%$ & 1 & $0,00 \%$ \\
\hline Szántás/ploughed field & $3,38 \%$ & 1 & $0,00 \%$ \\
\hline Öszi árpa/winter barley & $2,06 \%$ & 5 & $2,06 \%$ \\
\hline Repce/rape & $0,49 \%$ & 4 & $0,37 \%$ \\
\hline Egyéb/other & $10,00 \%$ & 1 & $0,00 \%$ \\
\hline Összesen / Total & $\mathbf{1 0 0 , 0 0 \%}$ & & $\mathbf{6 2 , 7 8 \%}$ \\
\hline
\end{tabular}

\subsection{A túzok élőhelyhasználata és választása a Borsodi-Mezőségben 2007-ben}

A Borsodi-Mezőség monitoring területén április, augusztus, december hónapokban a gyepterületek dominanciája jellemte a területet. Emellett a tavaszi időszakban közel 15-15\%ot repcetáblák és őszi búza táblák borítottak, és a napraforgó területek is megközelítették a 10\%-ot. A nyári hónapokban ez a borítás jelentősen megváltozott, augusztusban már a monitoring terület 37\%-án tarlókat találtunk. A decemberben a gyepek változatlan aránya mellett ismételten a gabonatáblák - elsősorban az őszi búza domináltak (52. ábra).

A túzok élőhelyhasználata (53. ábra) a gyepterületek dominanciáját mutatta. Emellett gyakran figyeltük meg a túzokokat a szántásokon, lucernán és a téli hónapokban repcetáblákon.

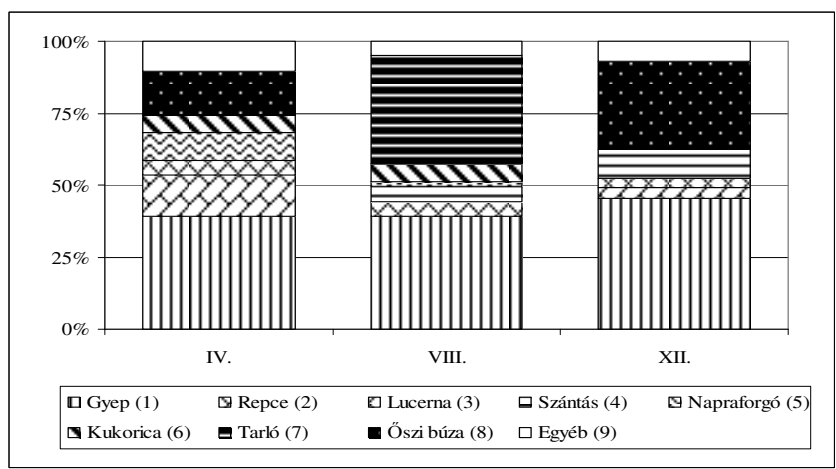

52. ábra: A Borsodi-Mezőség monitoring terület élőhelykínálata (2007)

Figure 52: Habitat availability in the Borsodi-Mezőség (2007)

1) Grassland, (2) Rape, (3) Alfalfa, (4) Ploughed field, (5) Sunflower, (6) Maize, (7) Stubble; (8) Winter wheat, (9) Other

A rendelkezésre álló élőhelyekkínálat és a használat aránya megmutatja a túzok élőhelypreferenciáját. Az IVLEV-indexek értékei alapján (54. ábra) a legpreferáltabb élőhelynek áprilisban és augusztusban a lucerna, míg decemberben a repce bizonyult. Emellett mindhárom hónapban - ha kisebb értékkel is - kedvelt élőhelyek voltak a gyepek.

A monitoring terület fészkelési időszakra vonatkozó minősítése - a biztonságos fészkelőhelynek ítélt gyepek, gabonák és a repce magas arányának köszönhetően - 75,32\%-os értéket eredményezett a területre (20. táblázat). 


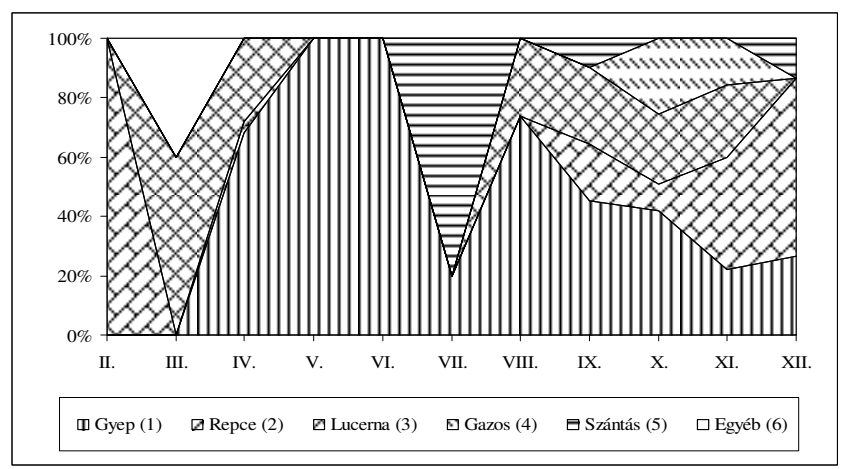

53. ábra: A túzok élőhelyhasználata a Borsodi-Mezőségben (2007)

Figure 53: Habitat use of the Great Bustard in Borsodi-Mezöség (2007)

(1) Grassland, (2) Rape, (3) Alfalfa, (4) Weedy, (5) Ploughed field, (6) Other

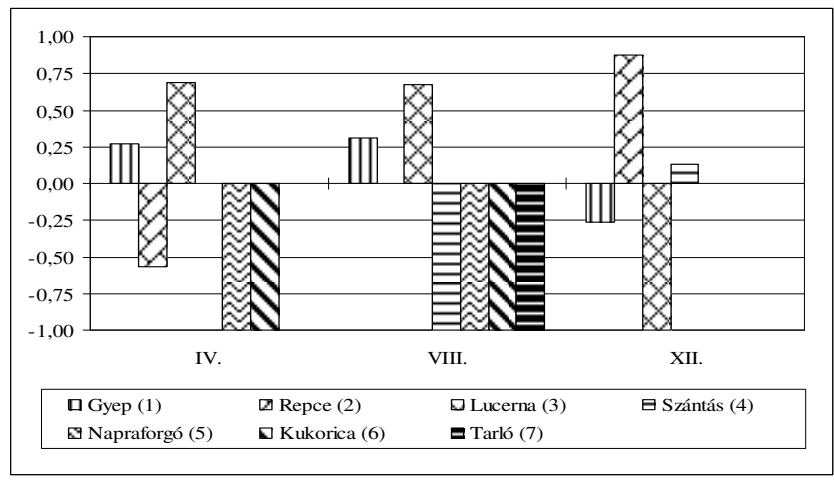

54. ábra: A túzok élőhelyválasztása (IVLEV index) a Borsodi-Mezőségben (2007)

Figure 54: IVLEV's electivity index of Great Bustard in the Borsodi-Mezőség (2007)

(1) Grassland, (2) Rape, (3) Alfalfa, (4) Ploughed field, (5) Sunflower, (6) Maize, (7) Stubble;

20. táblázat: A Borsodi-Mezőség élőhelyeinek minősítése tavasszal (2007)

Table 20: Qualification of habitats of the Borsodi-Mezőség area in spring (2007)

\begin{tabular}{|l|c|c|c|}
\hline \multicolumn{1}{|c|}{ Élöhely / Habitat } & $\begin{array}{c}\text { Terület } \\
\text { /Area \% }\end{array}$ & $\begin{array}{c}\text { Kategória } \\
\text { /Category }\end{array}$ & $\begin{array}{c}\text { Red. terület } \\
\text { /Red.area \% }\end{array}$ \\
\hline Gyep/grassland & $39,19 \%$ & 5 & $39,19 \%$ \\
\hline Kukorica/maize & $6,43 \%$ & 3 & $3,22 \%$ \\
\hline Öszi búza/winter wheat & $14,09 \%$ & 5 & $14,09 \%$ \\
\hline Lucerna/alfalfa & $5,09 \%$ & 1 & $0,00 \%$ \\
\hline Napraforgó/sunflower & $9,48 \%$ & 3 & $4,74 \%$ \\
\hline Öszi árpa/winter barley & $3,29 \%$ & 5 & $3,29 \%$ \\
\hline Repce/rape & $14,39 \%$ & 4 & $10,79 \%$ \\
\hline Egyéb/other & $8,04 \%$ & 1 & $0,00 \%$ \\
\hline Összesen / Total & $\mathbf{1 0 0 , 0 0 \%}$ & & $\mathbf{7 5 , 3 2 \%}$ \\
\hline
\end{tabular}

\subsection{A túzok élőhelyhasználata és választása a Borsodi-Mezőségben 2008-ban}

A gyepterületek túlsúlya jellemezte a Borsodi-Mezőséget 2008-ban is, emellett őszi búzatáblák foglaltak el nagy területeket (55. ábra). A gyepek aránya áprilisban több mint 45\%, az öszi búza is jócskán 30\% feletti értéket mutatott. Emellett közel 5\% lucerna, 9\% szántás és alig több mint $4 \%$ repce állt a túzokok rendelkezésére a területen. 


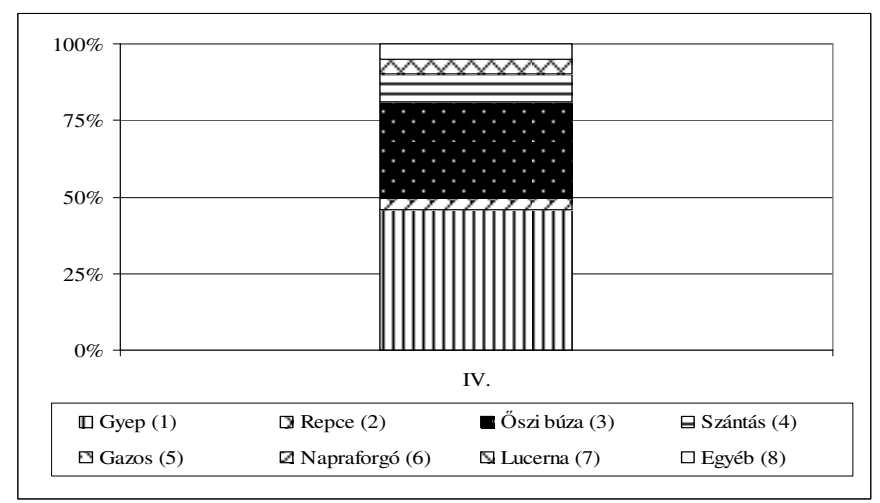

55. ábra: A Borsodi-Mezőségbeni monitoring terület élőhelykínálata (2008)

Figure 55: Habitat availability in the Borsodi-Mezőség (2008)

(1) Grassland, (2) Rape, (3) Winter wheat, (4) Ploughed field, (5) Weedy, (6) Sunflower, (7) Alfalfa, (8) Other

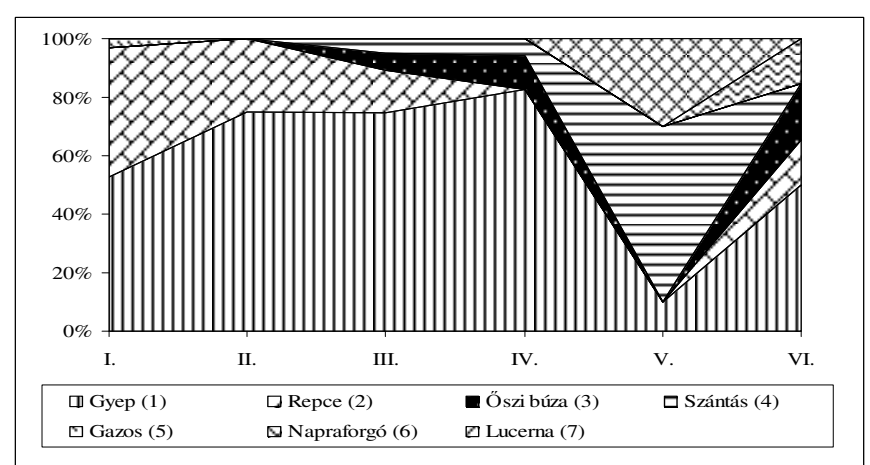

56. ábra: A túzok élőhelyhasználata a Borsodi-Mezőségben (2008)

Figure 56: Habitat use of the Great Bustard in the Borsodi-Mezőség (2008)

(1) Grassland, (2) Rape, (3) Winter wheat, (4) Ploughed field, (5) Weedy,

(6) Sunflower, (7) Alfalfa

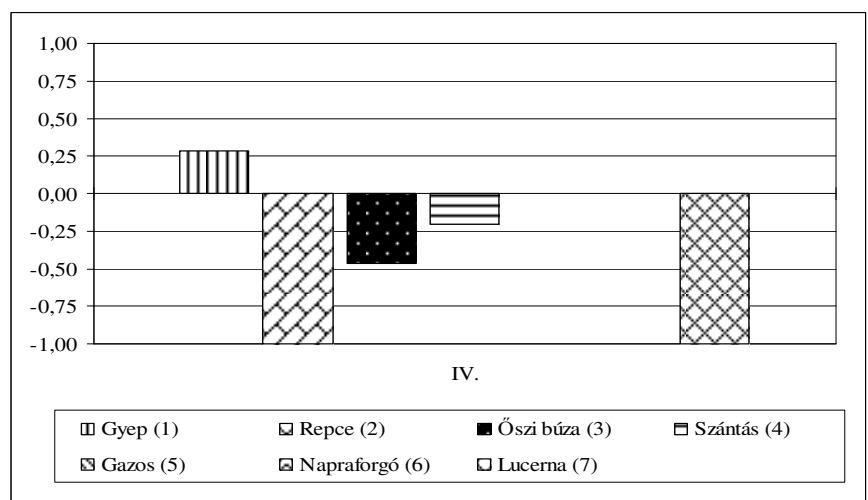

57. ábra: A túzok élőhelyválasztása (IVLEV index) a Borsodi-Mezőségben (2008)

Figure 57: IVLEV's electivity index of Great Bustard in the Borsodi-Mezőség (2008)

(1) Grassland, (2) Rape, (3) Winter wheat, (4) Ploughed field, (5) Weedy,

(6) Sunflower, (7) Alfalfa

A túzok élőhelyhasználata május hónap kivételével a gyepek nagyarányú dominanciáját mutatta (56. ábra). Emellett májusban a szántások és a lucerna, az év első, téli hónapjaiban 
pedig a repce használata volt kiemelkedő. Az IVLEV-indexek áprilisban a gyepek egyedüli preferenciájára mutatnak rá (57. ábra).

A monitoringterület fészkelés-szempontú minősítése $80 \%$ feletti értéket mutatott (21. táblázat), ami a gyepek és őszi búzatáblák magas arányának volt köszönhető.

\section{1. táblázat: A Borsodi-Mezőség élőhelyeinek minősítése tavasszal (2008)}

Table 21: Qualification of habitats of the Borsodi-Mezőség area in spring (2008)

\begin{tabular}{|l|c|c|c|}
\hline \multicolumn{1}{|c|}{ Élőhely / Habitat } & $\begin{array}{c}\text { Terület } \\
\text { /Area \% }\end{array}$ & $\begin{array}{c}\text { Kategória } \\
\text { /Category }\end{array}$ & $\begin{array}{c}\text { Red. terület } \\
\text { /Red.area \% }\end{array}$ \\
\hline Gyep/grassland & $45,64 \%$ & 5 & $45,64 \%$ \\
\hline Szántás/ploughed field & $8,77 \%$ & 1 & $0,00 \%$ \\
\hline Öszi gabona/winter cereals & $31,42 \%$ & 5 & $31,42 \%$ \\
\hline Lucerna/alfalfa & $4,81 \%$ & 1 & $0,00 \%$ \\
\hline Parlag/fallow & $0,26 \%$ & 5 & $0,26 \%$ \\
\hline Ugar/set-aside & $0,45 \%$ & 5 & $0,45 \%$ \\
\hline Repce/rape & $4,11 \%$ & 4 & $3,08 \%$ \\
\hline Egyéb/other & $4,54 \%$ & 1 & $0,00 \%$ \\
\hline Összesen / Total & $\mathbf{1 0 0 , 0 0 \%}$ & & $\mathbf{8 0 , 8 5 \%}$ \\
\hline
\end{tabular}

\section{HORTOBÁGY}

\subsection{A túzok élőhelyhasználata és választása a Hortobágyon 2005-ben}

A Hortobágy élőhelykínálatában (58. ábra) a gyepek aránya a tavaszi időszakban 23\%, nyáron 50\%, decemberben pedig $67 \%$ volt. Emellett a tavaszi időszakra a gabonafélék (föként őszi búza) magas arány volt jellemző. A nyári aratások után, augusztusban a tarlók aránya nőtt meg (31\%). A decemberi állapotfelmérés tanulsága szerint az „egyéb” növényzet aránya növkedett meg közel 20\%-ra, amely elsősorban őszi búzát, (lábon álló) napraforgót, és szántókat jelentett.

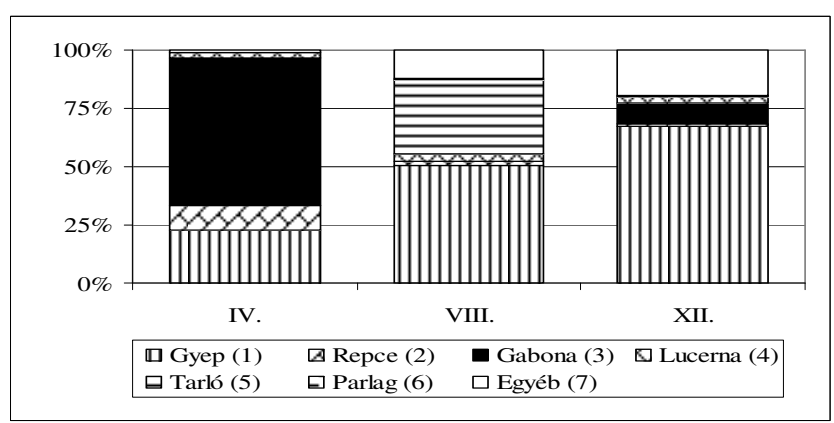

58. ábra: A Hortobágy élőhelykínálata (2005)

Figure 58: Habitat availability of the Hortobágy (2005)

(1) Grassland, (2) Rape, (3) Cereals, (4) Alfalfa, (5) Stubble, (6) Follow, (7) Other

A fenti kínálat mellett a 2005-ös év során a túzokok elsősorban a repcét, gyepet és a tarlót használták (59. ábra). Szeptembertől áprilisig a repce használata dominált, május-júniusban a gyepeket, míg augusztusban a tarlókat látogatták legszívesebben. 


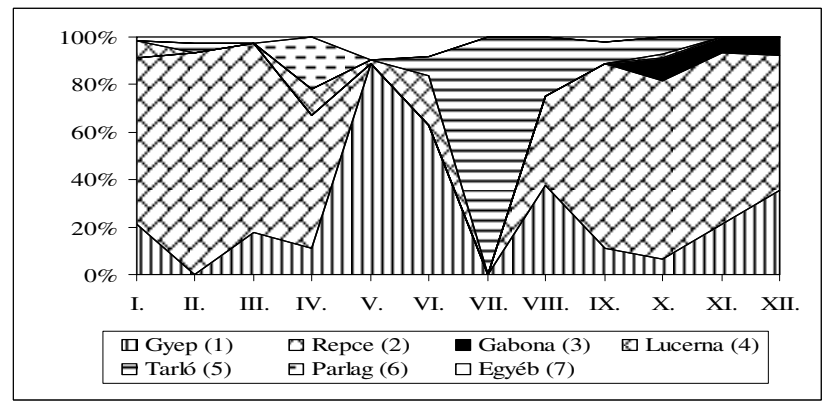

59. ábra: A túzok élőhelyhasználata a Hortobágyon (2005)

Figure 59: Habitat use of the Great Bustard of the Hortobágy (2005)

(1) Grassland, (2) Rape, (3) Cereals, (4) Alfalfa, (5) Stubble, (6) Follow, (7) Other

Az IVLEV-indexekkel kifejezett élőhelyválasztási adatok (60. ábra) mindhárom vizsgált hónapban (április, augusztus, december) a repce preferálását mutatták, noha az csak a terület 10\%-át borította. Emellett tavasszal legmagasabb IVLEV-index értéke a parlagnak volt 0,93 indexértékkel, noha annak borítása az 1\%-ot sem érte el a mintaterületen. A tavaszi időszakot emellett még a lucerna választása (Iv =0,67) jellemezte.

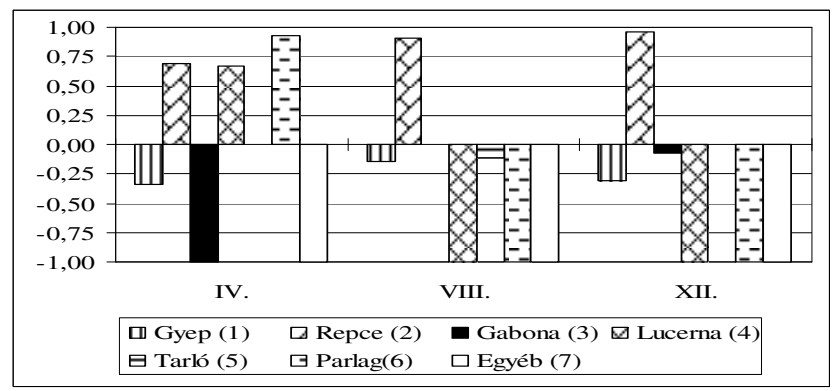

60. ábra: A túzok élőhelyválasztása (IVLEV-index) a Hortobágyon (2005)

Figure 60: IVLEV's electivity index of Great Bustard in the Hortobágy (2005)

(1) Grassland, (2) Rape, (3) Cereals, (4) Alfalfa, (5) Stubble, (6) Follow, (7) Other

A mintaterület fészkelési szempontból érdekes, tavaszi minősítése (22. táblázat) az összes hazai terület közül a legmagasabb volt 95,21\%-kal. Az eredmény jól mutatja, hogy a nagyiváni mintaterület mennyire alkalmas a túzok sikeres költéséhez.

22. táblázat: A Hortobágy élőhelyeinek minősítése tavasszal (2005)

Table 22: Qualification of habitats of the Hortobágy in spring (2005)

\begin{tabular}{|l|c|c|c|}
\hline \multicolumn{1}{|c|}{ Élöhely / Habitat } & $\begin{array}{c}\text { Terület } \\
\text { /Area \% }\end{array}$ & $\begin{array}{c}\text { Kategória } \\
\text { /Category }\end{array}$ & $\begin{array}{c}\text { Red. terület } \\
\text { /Red.area \% }\end{array}$ \\
\hline Gyep/grassland & $23,03 \%$ & 5 & $23,03 \%$ \\
\hline Lucerna/alfalfa & $2,24 \%$ & 1 & $0,00 \%$ \\
\hline Gabona/cereals & $63,56 \%$ & 5 & $63,56 \%$ \\
\hline Ugar/set-aside & $0,17 \%$ & 5 & $0,17 \%$ \\
\hline Repce/rape & $10,20 \%$ & 4 & $7,65 \%$ \\
\hline Parlag/fallow & $0,80 \%$ & 5 & $0,80 \%$ \\
\hline Összesen / Total & $\mathbf{1 0 0 , 0 0 \%}$ & & $\mathbf{9 5 , 2 1 \%}$ \\
\hline
\end{tabular}




\subsection{A túzok élőhelyhasználata és választása a Hortobágyon 2006-ban}

A hortobágyi mintaterület meghatározó élőhelytípusa változatlanul a gyep volt 2006-ban is. A tavaszi felmérés idején ez az habitat fedte a monitoring terület 67\%-át. Emellett még őszi búza, lucerna, tarlók, 1\%-nyi repce, és szántások voltak a meghatározó élőhelyek. A nyári időszakban a gyepek egy részén - a kaszálás után - már gyeptarlókat találtunk, és a gabonatarlók, lucerna aránya is megnőtt. Decemberben a tarlókon ismét gyepek találhatók, összességében a terület $75 \%$-át adva (61. ábra).

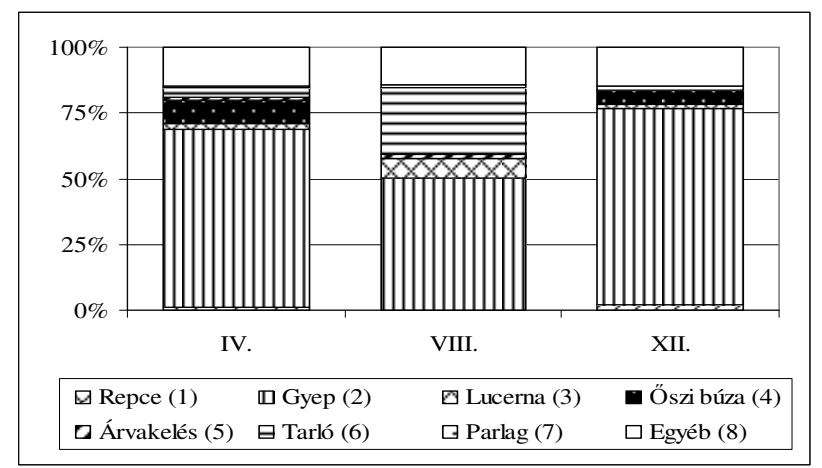

\section{1. ábra: A Hortobágyi monitoring terület élőhelykínálata (2006)}

Figure 61: Habitat availability in the Hortobágy (2006)

(1) Rape, (2) Grassland, (3) Alfalfa, (4) Winter wheat, (5) Volunteer crop, (6) Stubble, (7) Fallow, (8) Other

Sok hazai túzok előfordulási hellyel ellentétben a hortobágyi mintaterületen változatosnak mondható a faj élőhelyhasználata (62. ábra). Ez részben a folyamatos helykeresésnek, az esős időszak és az áradások okozta élőhelyvesztésnek (vízbotításnak) volt a következménye. Emellett megállapítható, hogy az év első és utolsó hónapjaiban a repce, a költési időszakban a gyepek, a lucerna és a parlagok, nyár végén és ősszel a lucerna dominanciáját folyamatosan felváltotta a repcéken való előfordulás.

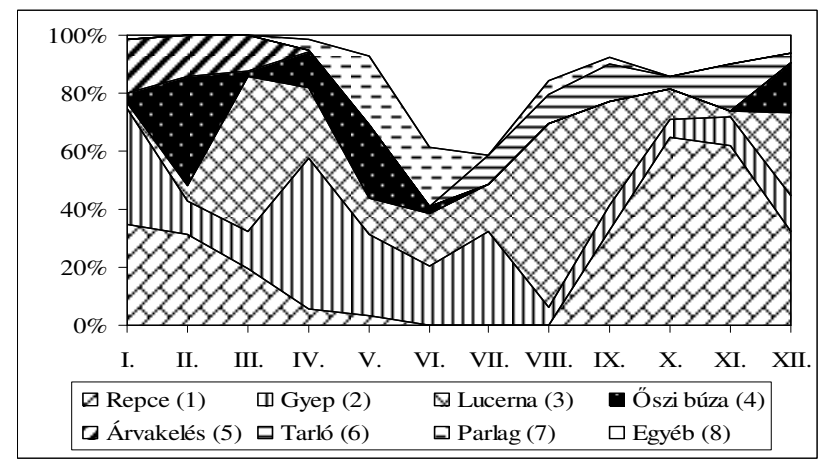

\section{2. ábra: A túzok élőhelyhasználata a Hortobágyon (2006)}

Figure 62: Habitat use of the Great Bustard in the Hortobágy (2006)

(1) Rape, (2) Grasslanf, (3) Alfalfa, (4) Winter wheat, (5) Volunteer crop, (6) Stubble, (7) Fallow, (8) Other

Tavasszal a repce, a lucerna és a parlag, nyáron a lucerna és a parlag, télen ismét a repce és a lucerna volt a leginkább preferált élőhelye a túzokoknak (63. ábra).

A költőhely szempontjából végzett élőhelyminősítési értékek tekintetében a hortobágyi gyepeket nem 5-ös értékkel kalkuláltuk, mivel a gyepeket kaszálták, alullegeltetettek voltak, illetve a költési időszakban jelentős területüket belvizek borították. A minősítés értéke 62,78\% lett (23. táblázat), azonban pont a fent is említett árvizek miatt a megtalált fészkek 
nem a mintaterület közeléből, hanem attól keletre és délre, szárazabb területekről kerültek elő 2006-ban.

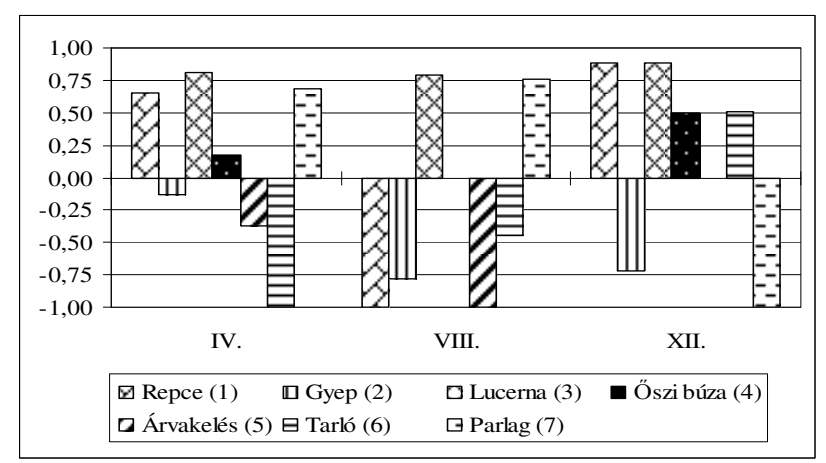

\section{3. ábra: A túzok élőhelyválasztása (IVLEV index) a Hortobágyon (2006)}

Figure 63: IVLEV's electivity index of Great Bustard in the Hortobágy (2006)

(1) Rape, (2) Grasslanf, (3) Alfalfa, (4) Winter wheat, (5) Volunteer crop, (6) Stubble, (7) Fallow

23. táblázat: A Hortobágy élőhelyeinek minősítése tavasszal (2006)

Table 23: Qualification of habitats of the Hortobágy in spring (2006)

\begin{tabular}{|l|c|c|c|}
\hline \multicolumn{1}{|c|}{ Élöhely / Habitat } & $\begin{array}{c}\text { Terület } \\
\text { /Area \% }\end{array}$ & $\begin{array}{c}\text { Kategória } \\
\text { /Category }\end{array}$ & $\begin{array}{c}\text { Red. terïlet } \\
\text { /Red.area \% }\end{array}$ \\
\hline Gyep/grassland & $67,39 \%$ & 4 & $50,54 \%$ \\
\hline Szántás/ploughed field & $14,53 \%$ & 1 & $0,00 \%$ \\
\hline Öszi búza/wheat & $9,44 \%$ & 5 & $9,44 \%$ \\
\hline Tarló/stubble & $3,42 \%$ & 1 & $0,00 \%$ \\
\hline Repce/rape & $1,16 \%$ & 4 & $0,87 \%$ \\
\hline Lucerna/alfalfa & $2,52 \%$ & 3 & $1,26 \%$ \\
\hline Parlag/Fallow & $0,66 \%$ & 5 & $0,66 \%$ \\
\hline Egyéb/Other & $0,87 \%$ & 1 & $0,00 \%$ \\
\hline Összesen / Total & $\mathbf{1 0 0 , 0 0 \%}$ & & $\mathbf{6 2 , 7 8 \%}$ \\
\hline
\end{tabular}

\subsection{A túzok élőhelyhasználata és választása a Hortobágyon 2007-ben}

A hortobágyi terület meghatározó élőhelytípusa változatlanul a gyep volt. Ez a habitat a tavaszi felméréseknél a monitoring terület $75 \%$-át fedte, és a későbbi felmérések során is változatlanul meghatározó maradt. A fennmaradó 25\%-ban jellemző volt még tavasszal az őszi búza, a lucerna és a szántások jelenléte. A nyári időszakban, az aratás után a gabonák helyén megjelentek a tarlók $(13,2 \%)$ és enyhén megemelkedett a lucerna és a napraforgó aránya. Decemberben jellemző volt a korábbiak mellett az őszi búza ismételt területfoglalása $(9,81 \%)$, emellett a gyepterületek arányának növekedése. A repcék legnagyobb területaránya (4,49\%) is ebben az évszakban volt jellemző (64. ábra).

A korábbi évekkel ellentétben a túzok élőhelyhasználata a hortobágyi élöhelyen is némileg leszükült (65. ábra). Bár megjelentek új élőhelytípusokon (pl. kukorica, napraforgó) összességében a területhasználat majdnem egész évben a gyepekre koncentrálódott. Az év elején tipikus volt a már korábban említett lucerna használata a klasszikus élőhelynek számító repce mellett, majd a gyepek erősödése, és a különböző, később elvetett termesztett növények területeinek elfoglalása (kukorica, napraforgó). Az év végére ismételten a repce és a lucerna vált meghatározó élőhellyé. 


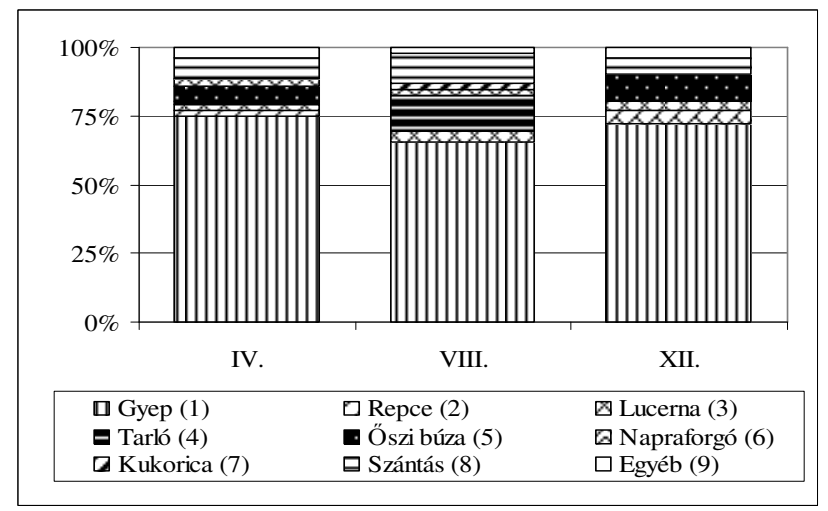

64. ábra: A hortobágyi monitoring terület élőhelykínálata (2007)

Figure 64: Habitat availability in the Hortobágy (2007)

(1) Grassland, (2) Rape, (3) Alfalfa, (4) Stubble, (5) Winter wheat, (6) Sunflower, (7) Maize, (8) Other;

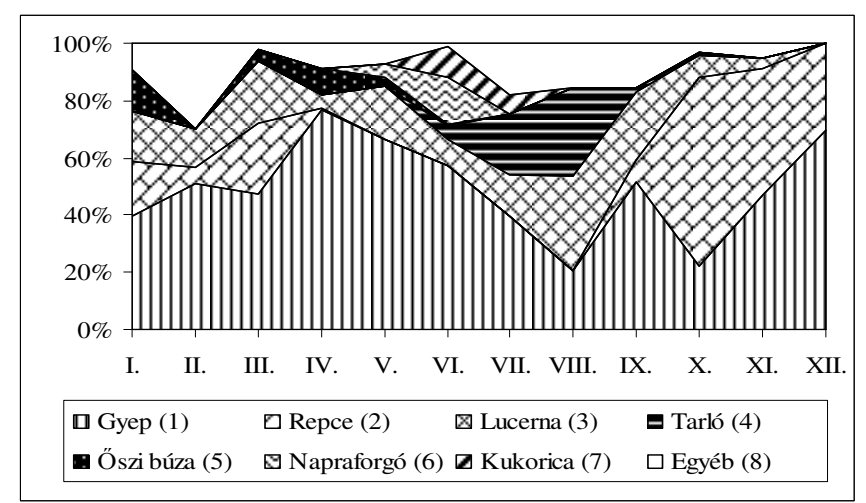

65. ábra: A túzok élőhelyhasználata a Hortobágyon (2007)

Figure 65: Habitat use of the Great Bustard in the Hortobágy (2007)

(1) Grassland, (2) Rape, (3) Alfalfa, (4) Stubble, (5) Winter wheat, (6) Sunflower, (7) Maize, (8) Other;

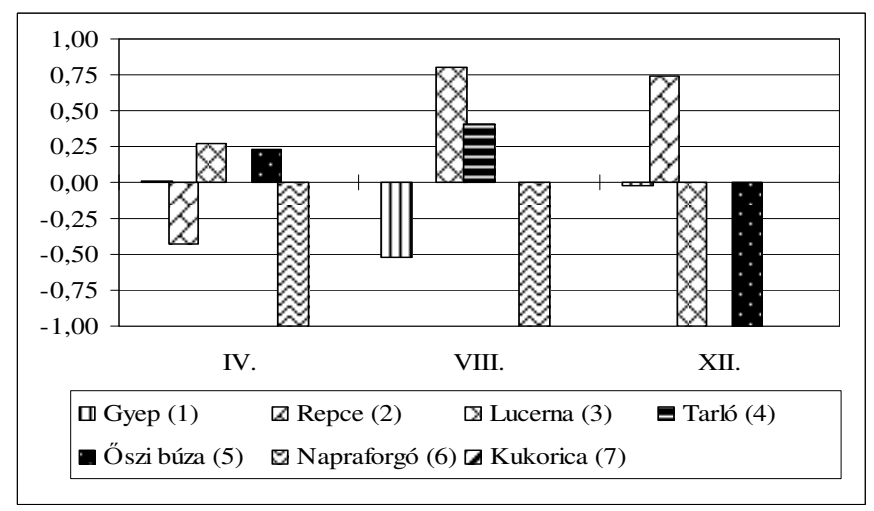

66. ábra: A túzok élőhelyválasztása (IVLEV index) a Hortobágyon (2007)

Figure 66: IVLEV's electivity index of Great Bustard in the Hortobágy (2007)

(1) Grassland, (2) Rape, (3) Alfalfa, (4) Stubble, (5) Winter wheat, (6) Sunflower, (7) Maize;

A preferenci vizsgálatok alapján megállapítható, hogy tavasszal a lucerna és az őszi búza, nyáron továbbra is a lucerna és a tartlók, míg télen a repce bizonyult a túzok által választott élőhelynek (66. ábra). 
24. táblázat: A Hortobágy élőhelyek minősítése tavasszal (2007)

Table 24: Qualification of habitats of the Hortobágy in spring (2007)

\begin{tabular}{|l|c|c|c|}
\hline \multicolumn{1}{|c|}{ Élőhely / Habitat } & $\begin{array}{c}\text { Terület } \\
\text { /Area \% }\end{array}$ & $\begin{array}{c}\text { Kategória } \\
\text { /Category }\end{array}$ & $\begin{array}{c}\text { Red. terület } \\
\text { /Red.area \% }\end{array}$ \\
\hline Gyep/grassland & $75,03 \%$ & 4 & $56,27 \%$ \\
\hline Szántás/ploughed fied & $7,83 \%$ & 1 & $0,00 \%$ \\
\hline Öszi búza/winter wheat & $5,61 \%$ & 5 & $5,61 \%$ \\
\hline Lucerna/alfalfa & $2,63 \%$ & 1 & $0,00 \%$ \\
\hline Ugar/set-aside & $1,52 \%$ & 5 & $1,52 \%$ \\
\hline Repce/rape & $1,84 \%$ & 4 & $1,38 \%$ \\
\hline Napraforgó/sunflower & $2,47 \%$ & 3 & $1,24 \%$ \\
\hline Egyéb/other & $3,07 \%$ & 1 & $0,00 \%$ \\
\hline Összesen / Total & $\mathbf{1 0 0 , 0 0 \%}$ & & $\mathbf{6 6 , 0 2 \%}$ \\
\hline
\end{tabular}

A költőhelyek veszélyeztetettsége szempontjából számított élőhely-minősítési értékek tekintetében a hortobágyi gyepeket továbbra is csak 4-es értékkel kalkuláltuk (eltérve ezzel az általános 5-ös bonitási értéktől), mivel a gyepek alullegeltettek és kaszáltak voltak. A redukált területarány 66,02\%-nak adódott (24. táblázat), ami a korábbi évnél magasabb érték. Mindezek ellenére - mint azt már korábbi években is hangsúlyoztuk - a megtalált fészkek továbbra sem a project területéről, hanem annak szélein, északi, keleti és déli irányból kerültek elö.

\subsection{A túzok élőhelyhasználata és választása a Hortobágyon 2008-ban}

A monitoring terület meghatározó élőhelytípusa 2008 áprilisában változatlanul a gyep volt. Az enyhe tavaszi időjárás és a kiegyenlített csapadékeloszlás következtében a területek tavaszi mủvelésbe vonása volt a jellemző. A gyepek arány $72 \%$ volt, a fennmaradó $28 \%$-on öszi búzát, őszi árpát, szántásokat, lucernát, repcét találtunk a felvételezéskor (67. ábra).

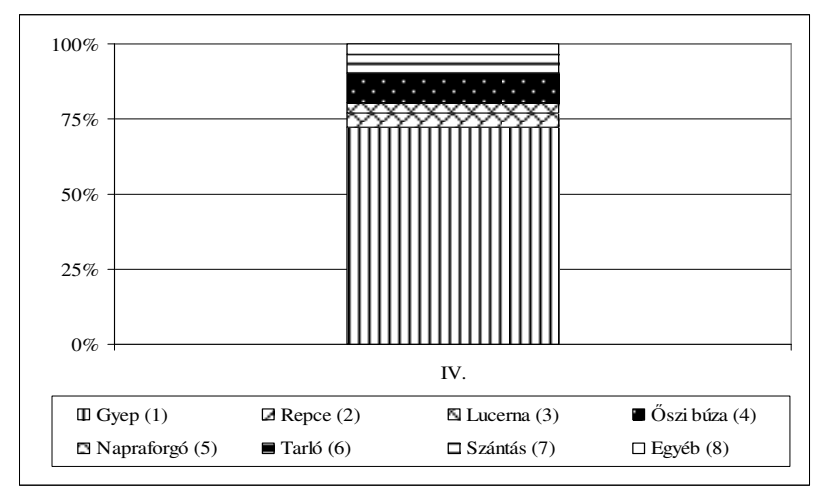

67. ábra: A hortobágyi monitoring terület élőhelykínálata (2008)

Figure 67: Habitat availability in the Hortobágy (2008)

(1) Grassland, (2) Rape, (3) Alfalfa, (4) Winter wheat, (5) Sunflower, (6) Stubble, (7) Ploughed field, (8) Other

A túzok élőhelyhasználata a gyepekre és a repcetáblákra koncentrálódott (68. ábra). A tavasz elörehaladtával a repce használata csökkent, újra a gyepterületen fordult elö leginkább egyéb klasszikus tavaszi élőhelyeken való megjelenése mellett (lucerna, őszi búza) és továbbra is bár csökkenő mértékben - a repcéken. 


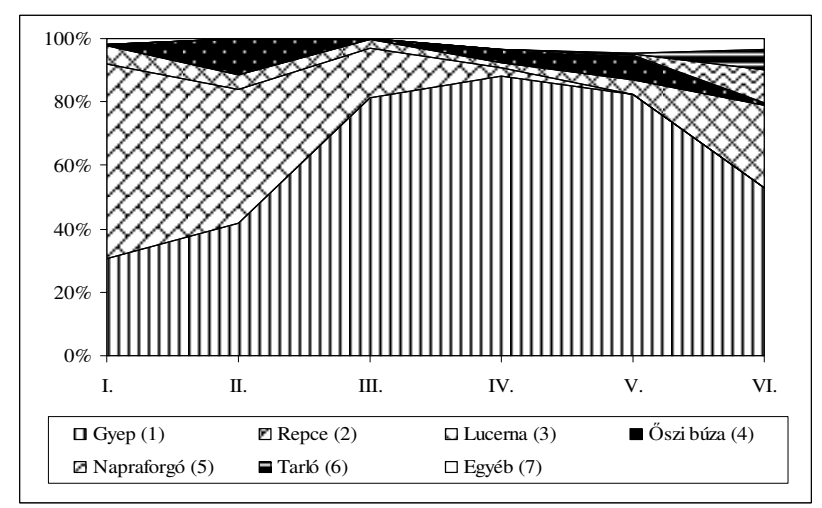

68. ábra: A túzok élőhelyhasználata a Hortobágyon (2007)

Figure 68: Habitat use of the Great Bustard in the Hortobágy (2007)

(1) Grassland, (2) Rape, (3) Alfalfa, (4) Winter wheat, (5) Sunflower, (6) Stubble, (7) Other

Noha a túzok előfordulási aránya a gyepek egyértelmü túlsúlyát mutatta, a kínálat függvényében, április hónapban nem ennyire markáns a preferencia. A repce, a lucerna és az őszi búza mindemellett nem bizonyult preferált élőhelynek a vizsgálati hónapban (69. ábra).

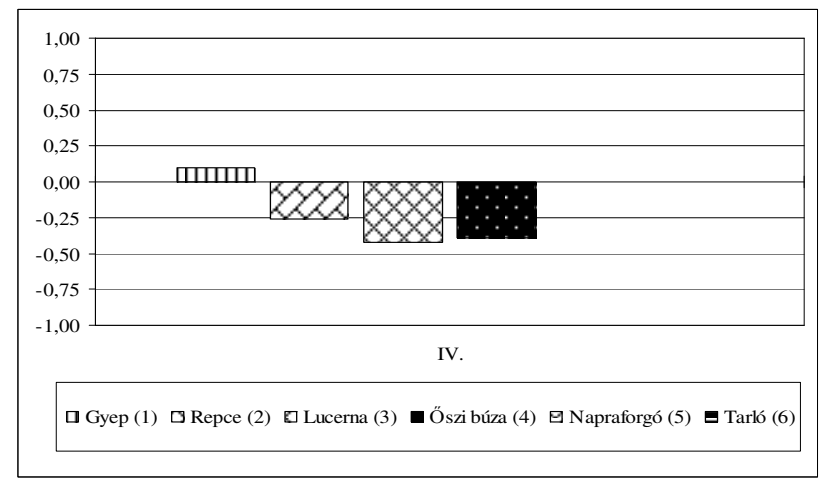

69. ábra: A túzok élőhelyválasztása (IVLEV index) a Hortobágyon (2007)

Figure 69: IVLEV's electivity index of Great Bustard in the Hortobágy (2007)

(1) Grassland, (2) Rape, (3) Alfalfa, (4) Stubble, (5) Winter wheat, (6) Sunflower, (7) Maize

25. táblázat: A Hortobágyi élőhelyeinek minősítése tavasszal (2008)

Table 25: Qualification of habitats of the Hortobágy in spring (2008)

\begin{tabular}{|l|c|c|c|}
\hline \multicolumn{1}{|c|}{ Élöhely / Habitat } & $\begin{array}{c}\text { Terület } \\
\text { /Area \% }\end{array}$ & $\begin{array}{c}\text { Kategória } \\
\text { /Category }\end{array}$ & $\begin{array}{c}\text { Red. terület } \\
\text { /Red.area \% }\end{array}$ \\
\hline Gyep/grassland & $72,30 \%$ & 4 & $54,23 \%$ \\
\hline Szántás/ploughed field & $6,25 \%$ & 1 & $0,00 \%$ \\
\hline Öszi búza/winter wheat & $9,81 \%$ & 5 & $9,81 \%$ \\
\hline Lucerna/alfalfa & $3,50 \%$ & 1 & $0,00 \%$ \\
\hline Öszi árpa/winter barley & $2,68 \%$ & 5 & $2,68 \%$ \\
\hline Repce/rape & $4,59 \%$ & 4 & $3,44 \%$ \\
\hline Egyéb/other & $0,87 \%$ & 1 & $0,00 \%$ \\
\hline Összesen / Total & $\mathbf{1 0 0 , 0 0 \%}$ & & $\mathbf{7 0 , 1 6 \%}$ \\
\hline
\end{tabular}

A költőhelyek veszélyeztetettsége szempontjából végzett élőhely-minősítési értékek tekintetében a hortobágyi gyepeket továbbra is csak 4-es értékkel kalkuláltuk, mivel azok müvelése nem volt minden tekintetben kedvező a túzok költésére nézve (alullegeltetés, kaszálás). A redukált területarány 70,16\%-nak adódott (25. táblázat), ami a korábbi évnél 
némileg ismét magasabb. Sajnos a fészkelési adatok még mindig azt támasztják alá, hogy ezek a gyepek nem minden esetben ideálisak a bizonságos költés szempontjából.

\section{BIHARI-SÍK}

\subsection{A túzok élőhelyhasználata és választása a Bihari-síkon 2005-ben}

A Bihari-síkon december hónapban a túzokok nem használták a monitoring területet, így a 2005-ös, téli élőhely kínálatot mutató térkép nem készült a területen. A tavaszi és nyári időszak élőhely kínálata közti fő különbség az volt, hogy a tavaszi gabona táblákat augusztusra tarlók váltották fel. Mindkét időszakban jellemző volt a gyepek magas aránya (közel 20\%), amely igen kedvezö volt a túzok számára. A fészkelés szempontjából szintén kedvező gabonafélék aránya tavasszal meghaladta a 28\%-ot (70. ábra).

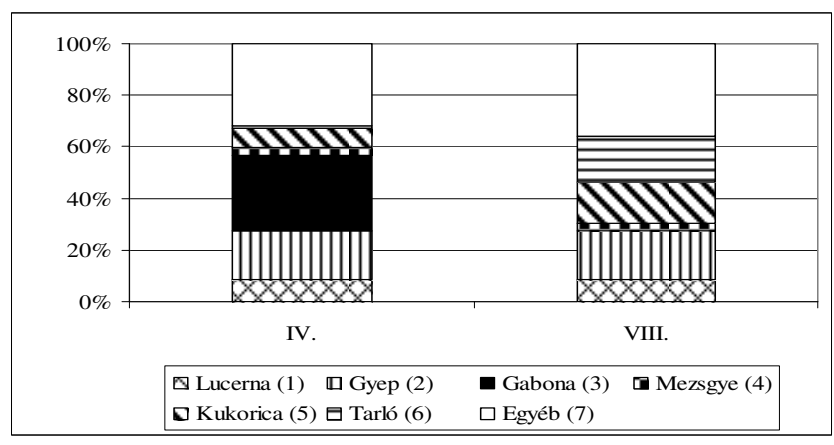

70. ábra: A Bihari-sík élőhelykínálata (2005)

Figure 70: Habitat availability of the Bihari-plain (2005)

(1) Alfalfa, (2) Grassland, (3) Cereals, (4) Balk (5) Maize, (6) Stubble, (7) Other

A túzok élőhelyhasználatát szemügyre véve (71. ábra) megállapíthatjuk, hogy elsősorban a gyepeket és a lucernát részesítette előnyben a faj. Mivel repce nem volt a mintaterületen, a téli hónapokban is elsősorban az előző két élőhelyen, valamint őszi gabonákon figyeltük meg a madarakat.

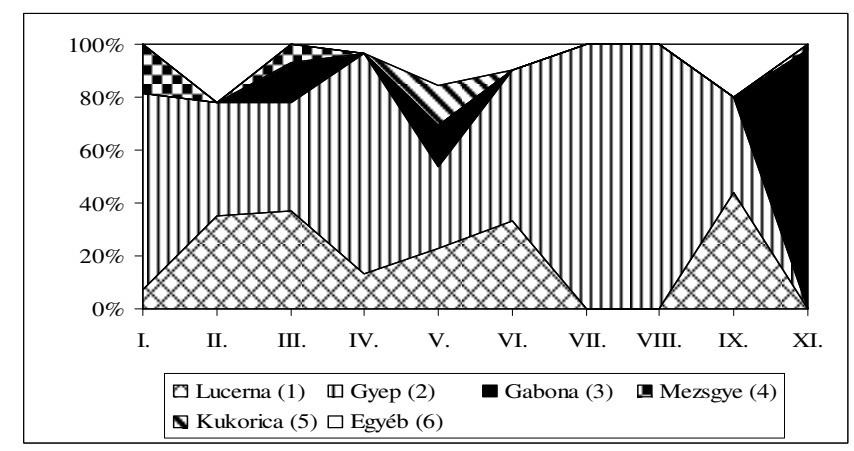

71. ábra: A túzok élőhelyhasználata a Bihari-síkon (2005)

Figure 71: Habitat use of the Great Bustard of the Bihari-plain (2005)

(1) Alfalfa, (2) Grassland, (3) Cereals, (4) Balk, (5) Maize, (6) Other

Az IVLEV-indexekkel kifejezett élőhelyválasztási értékek (72. ábra) a gyepek egyértelmü preferenciáját mutatták, áprilisban 0,63, augusztusban 0,68 értékekkel. A tavaszi időszakban preferált élőhely volt továbbá a lucerna $(0,21)$. 


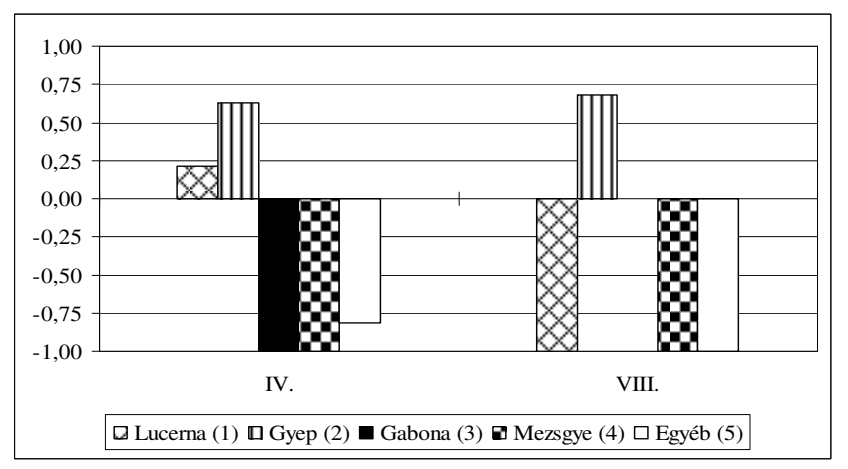

72. ábra: A túzok élőhelyválasztása (IVLEV-index) a Bihari-síkon (2005)

Figure 72: IVLEV's electivity index of Great Bustard in the Bihari-plain (2005)

(1) Alfalfa, (2) Grassland, (3) Cereals, (4) Balk, (5) Other

A fészkelés szempontjából végzett élőhely-minősítés (26. táblázat) 58\%-os értéke alacsonynak mondható, ami utal arra, hogy a térségben fokozott figyelmet kell fordítani a veszélyeztetett fészkek védelmére.

26. táblázat: A Bihari-sík élőhelyeinek minősítése tavasszal (2005)

Table 26: Qualification of habitats of the Bihari-plain in spring (2005)

\begin{tabular}{|l|c|c|c|}
\hline \multicolumn{1}{|c|}{ Élöhely / Habitat } & $\begin{array}{c}\text { Terület } \\
\text { /Area \% }\end{array}$ & $\begin{array}{c}\text { Kategória } \\
\text { /Category }\end{array}$ & $\begin{array}{c}\text { Red. terület } \\
\text { /Red.area \% }\end{array}$ \\
\hline Anyaggödör & $0,01 \%$ & 1 & $0,00 \%$ \\
\hline Cukorrépa/sugar beet & $2,31 \%$ & 2 & $0,58 \%$ \\
\hline Erdö/forest & $0,68 \%$ & 1 & $0,00 \%$ \\
\hline Erdötelepítés/afforestation & $0,76 \%$ & 1 & $0,00 \%$ \\
\hline Erdősáv/forest belt & $0,20 \%$ & 1 & $0,00 \%$ \\
\hline Gyep/grassland & $18,84 \%$ & 5 & $18,84 \%$ \\
\hline Kisparcellák/small plots & $3,85 \%$ & 1 & $0,00 \%$ \\
\hline Kukorica/maize & $7,43 \%$ & 3 & $3,72 \%$ \\
\hline Lucerna/alfalfa & $8,62 \%$ & 1 & $0,00 \%$ \\
\hline Mezsgye/balk & $0,37 \%$ & 1 & $0,00 \%$ \\
\hline Mezsgye-csatorna/balk channel & $2,69 \%$ & 1 & $0,00 \%$ \\
\hline Nádas/reeds & $0,12 \%$ & 1 & $0,00 \%$ \\
\hline Napraforgó/sunflower & $6,00 \%$ & 3 & $3,00 \%$ \\
\hline Öszi gabona/winter cereals & $28,17 \%$ & 5 & $28,17 \%$ \\
\hline Parlag/fallow & $1,53 \%$ & 5 & $1,53 \%$ \\
\hline Pillangós/legumes & $0,17 \%$ & 4 & $0,13 \%$ \\
\hline Szántás/ploughed fields & $14,35 \%$ & 1 & $0,00 \%$ \\
\hline Tanyahely/remain of farm-house & $0,74 \%$ & 1 & $0,00 \%$ \\
\hline Tarló/stubble & $1,10 \%$ & 1 & $0,00 \%$ \\
\hline Tavaszi gabona/spring cereals & $0,84 \%$ & 5 & $0,84 \%$ \\
\hline Trágyadepohely/dung ground & $0,02 \%$ & 1 & $0,00 \%$ \\
\hline Ugar/set-aside & $1,21 \%$ & 5 & $\mathbf{5 8 , 0 1 \%}$ \\
\hline Összesen/ Total & $\mathbf{1 0 0 , 0 0 \%}$ & & \\
\hline & & & \\
\hline
\end{tabular}




\subsection{A túzok élőhelyhasználata és választása a Bihari-síkon 2006-ban}

A Bihari-sík erősen mozaikos élőhelyü terület, intenzíven és félintenzíven müvelt szántók és a közéjük ékelődő 50-800 ha-os gyepterületek alkották 2006-ban is. A monitoring terület élőhelykínálatán (73. ábra) jól látható a gyepterületek állandó aránya, emellett a tavaszi időszakban szántások, őszi gabonák és lucerna jelenti az élőhely nagy hányadát. A nyári és téli időszakban az ,egyéb” területek aránya magas $(70 \%<)$, az erősen mozaikos élőhelyen ugyanis számos növénykultúra még az 1\%-os arányt sem éri el, így ezek feltüntetése terjedelmileg nem volt megoldható.

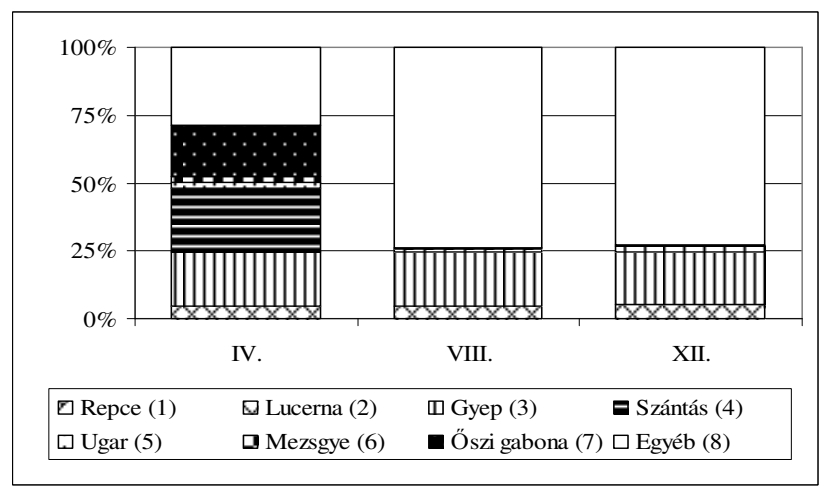

73. ábra: A Bihari-sík monitoring terület élőhelykínálata (2006)

Figure 73: Habitat availability in the Bihari-plain (2006)

(1) Rape, (2) Alfalfa, (3) Grassland, (4) Ploughed field, (5) Set-aside, (6) Balk,

(7) Winter cereals, (8) Other

Az év első három, valamint utolsó három hónapjában a túzokok kedvelt élőhelye a Biharban is a repce volt, annak ellenére, hogy az élöhelytípus kevesebb, mint 1\%-át adta a mintaterületnek. Emellett a téli időszakban a lucerna, az ugarok és a szántások voltak kedveltek a madarak körében. A gyepek állandóan látogatottaknak bizonyultak, különösen a tavaszi-nyári időszakban (74. ábra).

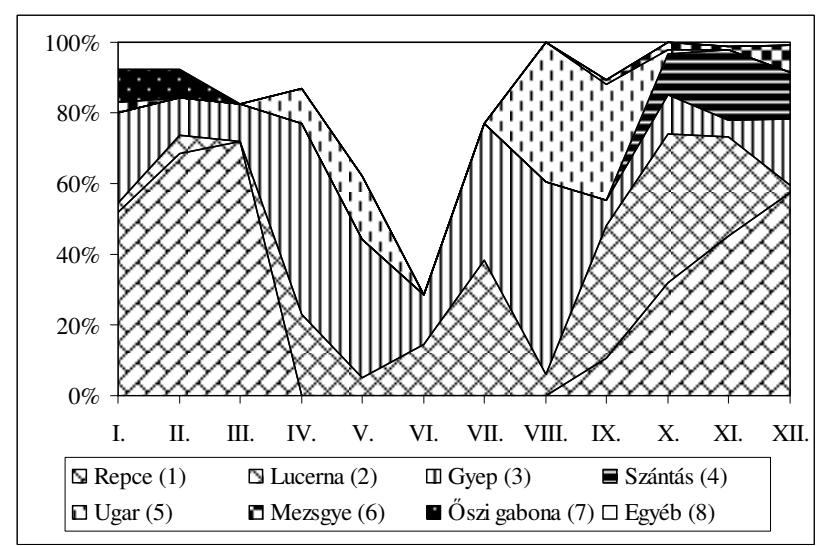

74. ábra: A túzok élőhelyhasználata a Bihari-síkon (2006)

Figure 74: Habitat use of the Great Bustard in the Bihari-plain (2006)

(1) Rape, (2) Alfalfa, (3) Grassland, (4) Ploughed field, (5) Set-aside, (6) Balk,

(7) Winter cereals, (8) Other

Az élőhelyválasztási számítások (75. ábra) is jól szemléltetik a lucerna (tavasz, nyár), az ugarok (tavasz, nyár), a gyepek (tavasz-nyár), a szántások (tél) és repcék (tél) preferenciáit Biharban. 


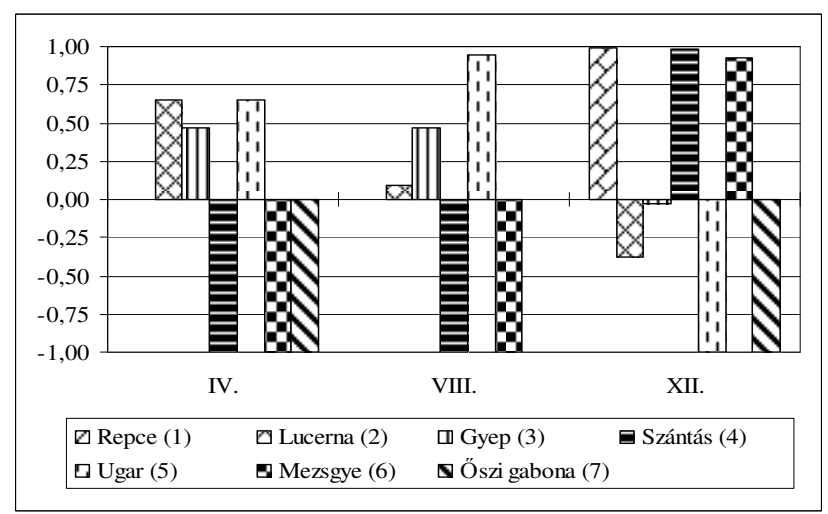

75. ábra: A túzok élőhelyválasztása (IVLEV index) a Bihari-síkon (2006)

Figure 75: IVLEV's electivity index of Great Bustard in the Bihari-plain (2006)

(1) Rape, (2) Alfalfa, (3) Grassland, (4) Ploughed field, (5) Set-aside, (6) Balk, (7) Winter cereals

A terület tavaszi, fészkelés szempontú minősítése (27. táblázat) - a fészkelésre alkalmatlan területek (tarlók, szántások) magas aránya miatt - alacsony 37,92\%-os értékkel volt jellemezhető. A gyepek és gabonák intenzív használat miatta ezen élőhelyek is csak 4-es kategóriaértékkel szerepeltek az értékelés során.

27. táblázat: A Bihari-sík élőhelyeinek minősítése tavasszal (2006)

Table 27: Qualification of habitats of the Bihari-plain in spring (2006)

\begin{tabular}{|l|c|c|c|}
\hline \multicolumn{1}{|c|}{ Élóhely / Habitat } & $\begin{array}{c}\text { Terület } \\
\text { /Area \% }\end{array}$ & $\begin{array}{c}\text { Kategória } \\
\text { /Category }\end{array}$ & $\begin{array}{c}\text { Red. terület } \\
\text { /Red.area \% }\end{array}$ \\
\hline Szántás/ploughed field & 23,58 & 1 & $0,00 \%$ \\
\hline Gyep/grassland & 19,65 & 4 & $14,73 \%$ \\
\hline Öszi gabona/winter cereals & 18,62 & 4 & $13,96 \%$ \\
\hline Kisparcellák/small plots & 12,29 & 4 & $9,22 \%$ \\
\hline Tarló/stubble & 6,98 & 1 & $0,00 \%$ \\
\hline Magágy/seedbed & 6,19 & 1 & $0,00 \%$ \\
\hline Lucerna/alfalfa & 4,82 & 1 & $0,00 \%$ \\
\hline Egyéb/other & 7,87 & 1 & $0,00 \%$ \\
\hline Összesen / Total & $\mathbf{1 0 0 , 0 0 \%}$ & & $\mathbf{3 7 , 9 2 \%}$ \\
\hline
\end{tabular}

\subsection{A túzok élőhelyhasználata és választása a Bihari-síkon 2007-ben}

2007-ben a túzok számára jelentős élőhelytípusok közül a tavasszal az őszi-gabonák, a kukorica, valamint a gyepek aránya volt meghatározó. Nyár végén a gabonákat a tartlók váltották fel, valamint megemelkedett a napraforó aránya is a területen. Télen aztán a tarlók, a szántások és őszi gabona jelentek meg. Mindössze két repcetábla volt a monitoring területen a téli időszakban (76. ábra). A gyepek folyamatosan 20\%-át borították a területnek. Az „egyéb” növényzetnek jelölt élőhelyek nagy része is „,kisparcellákon” tenyésztek. 


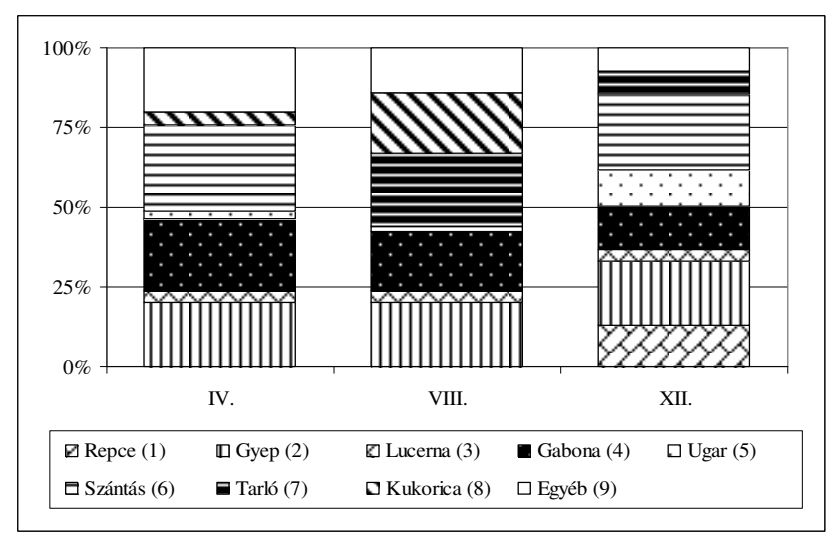

76. ábra: A Bihari-síki monitoring terület élőhelykínálata (2007)

Figure 76: Habitat availability in the Bihari-plain (2007)

(1) Rape, (2) Grassland, (3) Alfalfa, (4) Cereal, (5) Fallow, (6) Ploughed field, (7) Stubble, (8) Maize, (9) Other

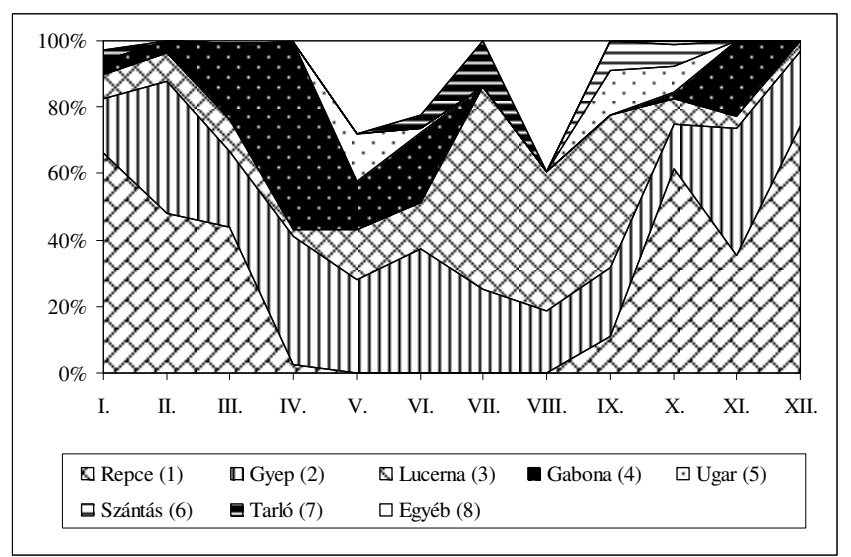

77. ábra: A túzok élőhelyhasználata a Bihari-síkon (2007)

Figure 77: Habitat use of the Great Bustard in Bihari-plain (2007)

(1) Rape, (2) Grassland, (3) Alfalfa, (4) Cereal, (5) Fallow, (6) Ploughed field, (7) Stubble, (8) Other

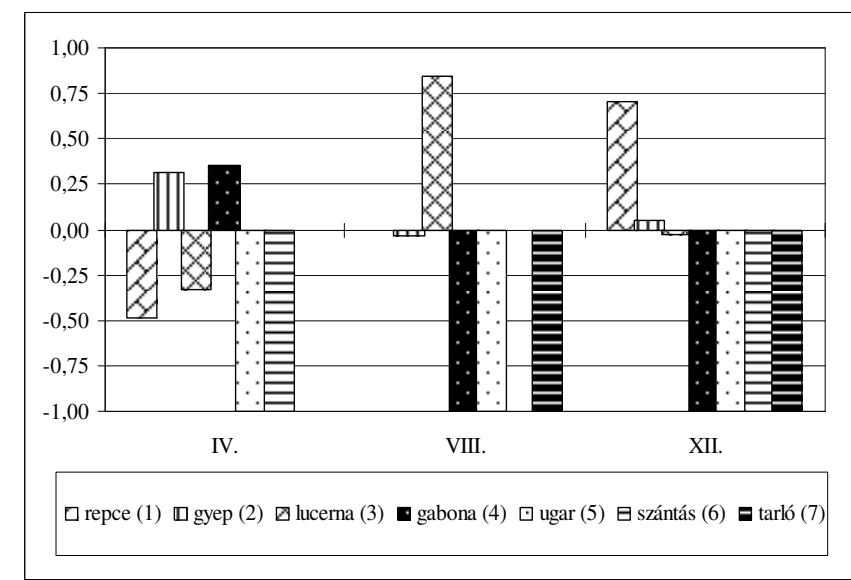

78. ábra: A túzok élőhelyválasztása (IVLEV index) a Bihari-síkon (2007)

Figure 78: IVLEV's electivity index of Great Bustard in the Bihari-plain (2007)

(1) Rape, (2) Grassland, (3) Alfalfa, (4) Cereal, (5) Fallow, (6) Plaughed field, (7) Srubble

A legtöbb hazai túzokvédelmi területtel ellentétben, Biharban nagyon változatos képet mutatott a túzok 2007-es élőhelyhasználata (77. ábra). A téli hónapokban a repce 
használatának dominanciája ugyan itt is megfigyelhető volt, de az év többi időszakában egyaránt használták a gyepeket, az őszi búzát, a lucernát, az ugarokat és a tarlókat a madarak.

Az IVLEV-index rámutat ugyanakkor a gyepek és gabonák tavaszi preferenciájára. Nyáron a lucerna bizonyult preferált élőhelynek (78. ábra).

A monitoring terület fészkelési szempontú minősítése 48,17\%-os eredményt hozott (28. táblázat). Ez 10\%-al magasabb, mint a 2006-ban számított érték volt, ami elsősorban a gyepek, és gabonák arányában bekövetkezett növekedésnek tudható be. A gyepeket és gabonatáblákat ezúttal is csak 4-es szorzóval vettük figyelembe, a nem minden esetben túzokbarát kezelésük miatt.

28. táblázat: A Bihari-sík élőhelyeinek minősítése tavasszal (2007)

Table 28: Qualification of habitats of the Bihari-plain in spring (2007)

\begin{tabular}{|l|c|c|c|}
\hline \multicolumn{1}{|c|}{ Élőhely / Habitat } & $\begin{array}{c}\text { Terület } \\
\text { /Area \% }\end{array}$ & $\begin{array}{c}\text { Kategória } \\
\text { /Category }\end{array}$ & $\begin{array}{c}\text { Red. terület } \\
\text { /Red.area \% }\end{array}$ \\
\hline Szántás/ploughed field & $27,00 \%$ & 1 & $0,00 \%$ \\
\hline Gyep/grassland & $20,16 \%$ & 4 & $15,12 \%$ \\
\hline Öszi gabona/winter cereals & $22,64 \%$ & 4 & $16,98 \%$ \\
\hline Kisparcellák/small plots & $13,01 \%$ & 4 & $9,76 \%$ \\
\hline Kukorica/maize & $4,15 \%$ & 5 & $4,15 \%$ \\
\hline Ugar/set-aside & $2,16 \%$ & 5 & $2,16 \%$ \\
\hline Lucerna/alfalfa & $3,56 \%$ & 1 & $0,00 \%$ \\
\hline Egyéb/other & $7,32 \%$ & 1 & $0,00 \%$ \\
\hline Összesen / Total & $\mathbf{1 0 0 , 0 0 \%}$ & & $\mathbf{4 8 , 1 7 \%}$ \\
\hline
\end{tabular}

\subsection{A túzok élőhelyhasználata és választása a Bihari-síkon 2008-ban}

A Bihari-sík monitoring terület 2008. tavaszi élőhelyállapota némileg különbözött 2007 azonos időszakától. A korábban kiterjedten előforduló „kisparcellákat” sok helyen gyepek, és gabonák váltották fel, amit kedvező fordulatként értékelhettünk a túzokvédelem szempontjából. A repce területaránya is növekedett az előző évekhez képest, és reményeink szerint ez a folyamat a jövőben is folytatódni fog. A szántások mellett az őszi gabona és a gyepek területfoglalása volt maghatározó áprilisban (79. ábra).

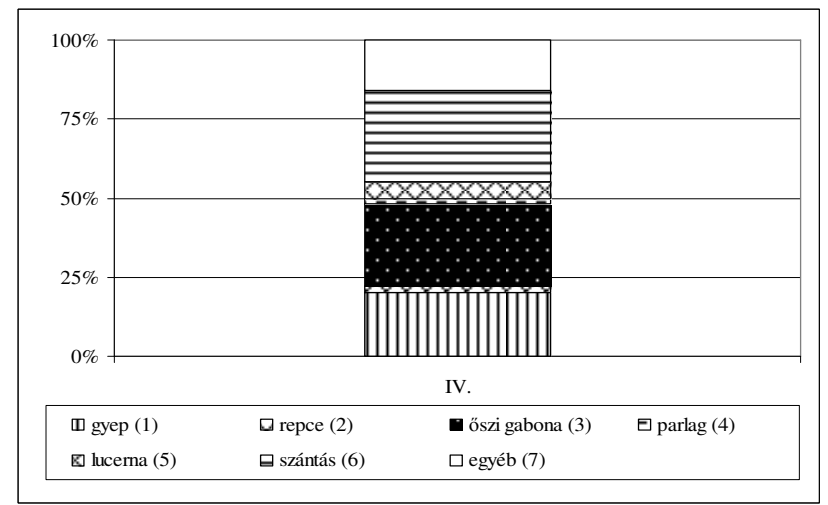

79. ábra: A Bihari-síki monitoring terület élőhelykínálata (2008)

Figure 79: Habitat availability in the Bihari-plain (2008)

(1) Grassland, (2) Rape, (3) Winter wheat, (4) Fallow, (5) Alfalfa (6) Ploughed field, (7) Other 
A túzok élőhelyfoglalását a gyepterületek és a repce használata jellemezte. A tavasz kezdetétől a repce használata csökkent, és a madarak egyre növekvő arányban kezdték látogatni a parlagterületeket, a szántásokat és a napraforgókat (80. ábra).

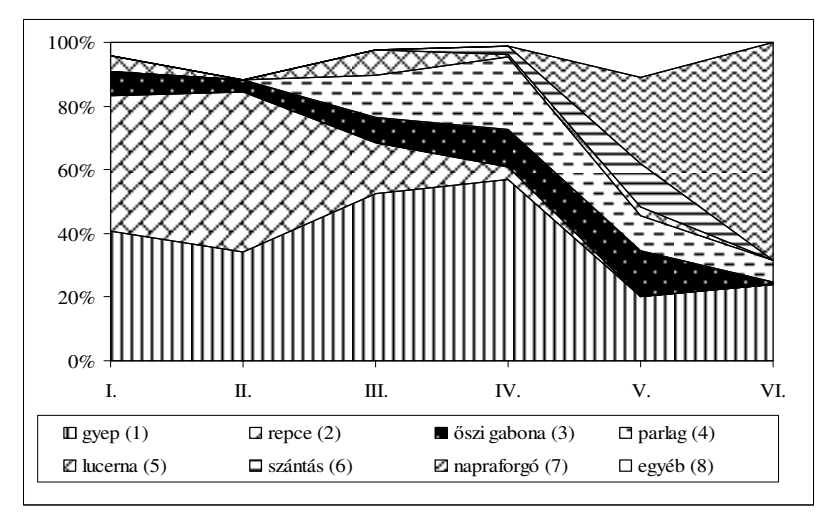

\section{0. ábra: A túzok élőhelyhasználata a Bihari-síkon (2008)}

Figure 80: Habitat use of the Great Bustard in the Bihari-plain (2008)

(1) Grassland, (2) Rape, (3) Winter wheat, (4) Fallow, (5) Alfalfa

(6) Ploughed field, (7) Sunflower, (8) Other;

Az élőhely preferencia adatok e csonka évben csak április hónapról állnak rendelkezésünkre. A tavasszal a túzok a parlagokat, a gyepeket és a repcét preferálta a Bihari-síkon (81. ábra).

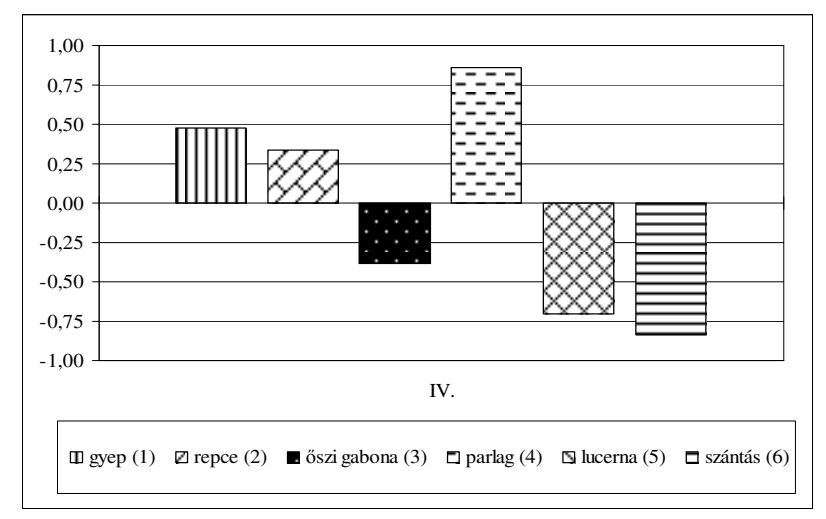

81. ábra: A túzok élőhelyválasztása (IVLEV index) a Bihari-síkon (2008)

Figure 81: IVLEV's electivity index of Great Bustard in the Bihari-plain (2008)

(1) Grassland, (2) Rape, (3) Winter wheat, (4) Fallow, (5) Alfalfa (6) Ploughed field

29. táblázat: A Bihari-sík élőhelyeinek minősítése tavasszal (2008)

Table 29: Qualification of habitats of the Bihari-plain in spring (2008)

\begin{tabular}{|l|c|c|c|}
\hline \multicolumn{1}{|c|}{ Élöhely / Habitat } & $\begin{array}{c}\text { Terület } \\
\text { /Area \% }\end{array}$ & $\begin{array}{c}\text { Kategória } \\
\text { /Category }\end{array}$ & $\begin{array}{c}\text { Red. terület } \\
\text { /Red.area \% }\end{array}$ \\
\hline Szántás/ploughed field & 28,72 & 1 & $0,00 \%$ \\
\hline Gyep/grassland & 20,22 & 4 & $15,17 \%$ \\
\hline Öszi gabona/winter cereals & 26,08 & 4 & $19,56 \%$ \\
\hline Kisparcellák/small parcels & 11,24 & 4 & $8,43 \%$ \\
\hline Parlag/fallow & 1,69 & 5 & $1,69 \%$ \\
\hline Repce/rape & 1,95 & 4 & $1,46 \%$ \\
\hline Lucerna/alfalfa & 5,30 & 1 & $0,00 \%$ \\
\hline Egyéb/other & $4,80 \%$ & 1 & $0,00 \%$ \\
\hline Összesen / Total & $\mathbf{1 0 0 , 0 0 \%}$ & & $\mathbf{4 6 , 3 1 \%}$ \\
\hline
\end{tabular}


A monitoring terület minősítése során nyert érték 2\%-al maradt el a 2007-es év azonos adataitól. Sajnos még mindig alacsony a fészkelésre kifejezetten alkalmas gyepterületek aránya, ezzel szemben az arra alkalmatlan szántások közel 30\%-át borították a területnek (29. táblázat). A 46,31\%-os érték ismét alacsonynak nevezhető.

\section{DÉVAVÁNYA}

\subsection{A túzok élőhelyhasználata és választása Dévaványán 2005-ben}

A dévaványai projectterület élőhely kínálata a gyepek magas arányával (>30\%) egész évben jellemezhető volt, amely adottság kedvező feltételeket teremtett a túzokok számára. Szintén pozitív tényező volt az ôszi búza magas aránya, amely a tavaszi és téli időszakban (április, december) több mint 20\%-át borította a területnek (82. ábra).

A túzok dévaványai élőhelyhasználatát (83. ábra) megvizsgálva megállapítható, hogy elsősorban a repcék, a gyepek, a szántások és a napraforgótáblák voltak kedvelt tartózkodási helyei a madaraknak.

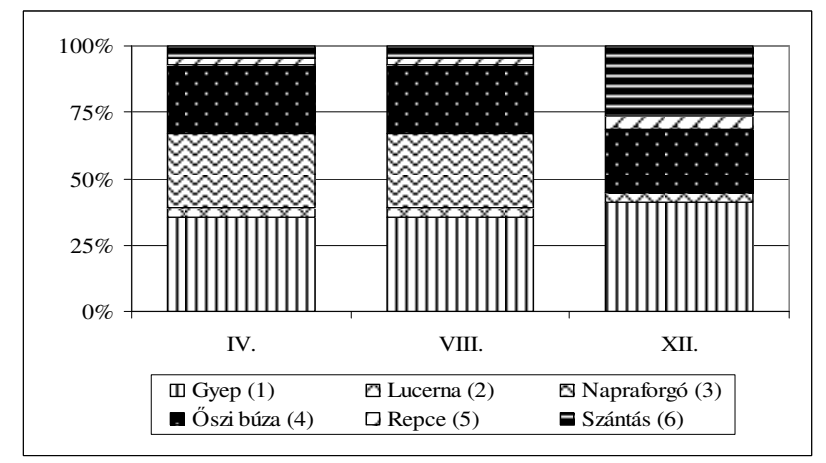

82. ábra: A dévaványai monitoring terület élőhelykínálata (2005)

Figure 82: Habitat availability of the Dévaványa monitoring area (2005)

(1) Grassland, (2) Alfalfa, (3) Sunflower, (4) Winter wheat (5) Rape, (6) Stubble

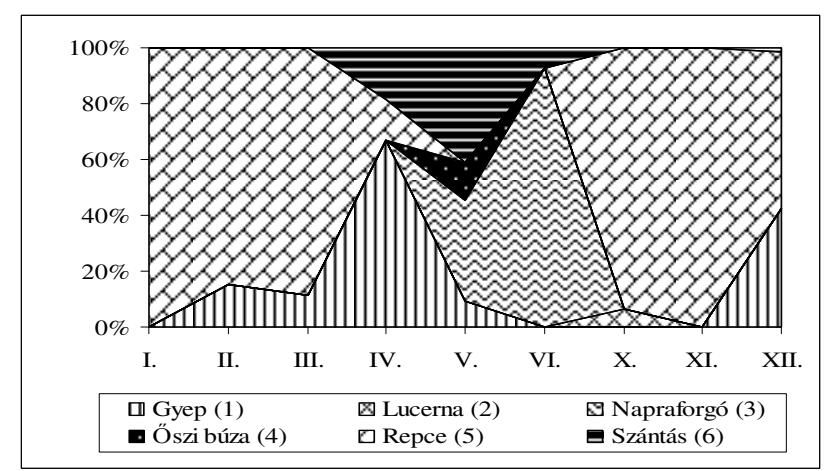

83. ábra: A túzok élőhelyhasználata a dévaványai mintaterületen (2005)

Figure 83: Habitat use of the Great Bustard of the Dévaványa monitroing area (2005)

(1) Grassland, (2) Alfalfa, (3) Sunflower, (4) Winter wheat (5) Rape, (6) Stubble

Az IVLEV-indexek (84. ábra) is hasonló preferenciákat mutattak ki, kiemelve a repce fontosságát. Emellett a gyepek, valamint áprilisban a szántások számítottak preferált élőhelynek. Augusztus hónapban nem volt megfigyelt egyed a monitoring területen, így a nyári élöhely-választási indexek számítását nem tudtuk elvégezni. 


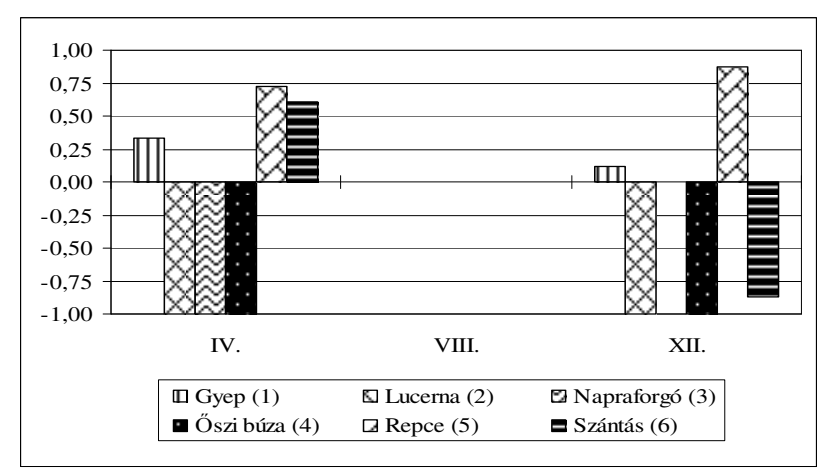

\section{4. ábra: A túzok élőhelyválasztása (IVLEV-index) a dévaványai monitoring területen}

Figure 84: IVLEV's electivity index of Great Bustard in the Dévaványa monitoring area (2005)

(1) Grassland, (2) Alfalfa, (3) Sunflower, (4) Winter wheat (5) Rape, (6) Stubble

A fenti tényezőknek köszönhető, hogy a dévaványai élőhely fészkelési szempontú minősítése a harmadik legmagasabb értéket érte el a hazai LIFE területek között, amely mutatja a térség kiemelt szerepét a túzokállomány védelmében (30. táblázat).

30. táblázat: A dévaványa monitoring terület bonitása tavasszal (2005)

Table 30: Spring bonity of the Dévaványa monitroing area (2005)

\begin{tabular}{|l|c|c|c|}
\hline \multicolumn{1}{|c|}{ Élőhely/Habitat } & $\begin{array}{c}\text { Terület / } \\
\text { Area }\end{array}$ & $\begin{array}{c}\text { Bonítás érték/ } \\
\text { Bonity }\end{array}$ & $\begin{array}{c}\text { Redukált terület/ } \\
\text { Reduced area }\end{array}$ \\
\hline Erdö/forest & $0,30 \%$ & 1 & $0,00 \%$ \\
\hline Fénymag/canary grass & $2,37 \%$ & 1 & $0,00 \%$ \\
\hline Gyep/grassland & $33,60 \%$ & 5 & $33,60 \%$ \\
\hline Kukorica/maize & $0,71 \%$ & 3 & $0,35 \%$ \\
\hline Lucerna/alfalfa & $3,17 \%$ & 1 & $0,00 \%$ \\
\hline Napraforgó/sunflower & $26,42 \%$ & 3 & $13,21 \%$ \\
\hline Öszi kalászos/winter cereals & $24,32 \%$ & 5 & $24,32 \%$ \\
\hline Repce/rape & $2,36 \%$ & 4 & $1,77 \%$ \\
\hline Szántás/stubble & $4,51 \%$ & 1 & $0,00 \%$ \\
\hline Ugar/fallow & $2,23 \%$ & 5 & $2,23 \%$ \\
\hline Összesen / Total & $\mathbf{1 0 0 , 0 0 \%}$ & & $\mathbf{7 5 , 4 8 \%}$ \\
\hline
\end{tabular}

\subsection{A túzok élőhelyhasználata és választása Dévaványán 2006-ban}

A dévaványai monitoring területet 2006-ban is a gyepterületek és változatos szerkezetü agrárterületek (szántók) jellemezték (85. ábra). A gyepek állandó aránya (33\%) mellett változó helyzettel, de közel azonos arányban (20-26\%) szántásokat (illetve tárcsázott táblákat), és őszi kalászosokat találhattunk a területen. A repce aránya tavasszal 3,9\%, télen $10 \%$ volt, míg augusztusban nem volt repce a területen. Emellett az ugar, a lucerna és őszi kalászos területek voltak meghatározóak a térség élőhely kínálata szempontjából.

A túzokok élőhelyválasztását a repce preferenciája jellemezte azokban a hónapokban, amikor ez elérhető volt számukra. A tavaszi-nyári hónapokban a lucernaföldek, parlag- és gyepterületek, árvakelések bizonyultak kedvelt élőhelyeknek, míg a téli időszakban a repce mellett szívesen látogatták az őszi búzát is (86. ábra). 


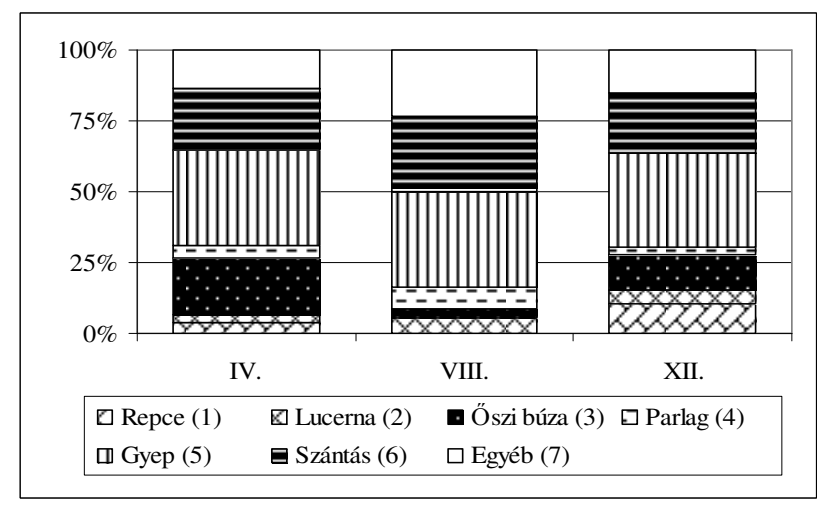

85. ábra: A dévaványai monitoring terület élőhelykínálata (2006)

Figure 85: Habitat availability in Dévaványa (2006)

(1) Rape, (2) Alfalfa, (3) Winter wheat, (4) Fallow, (5) Grassland, (6) Ploughed field, (7) Other

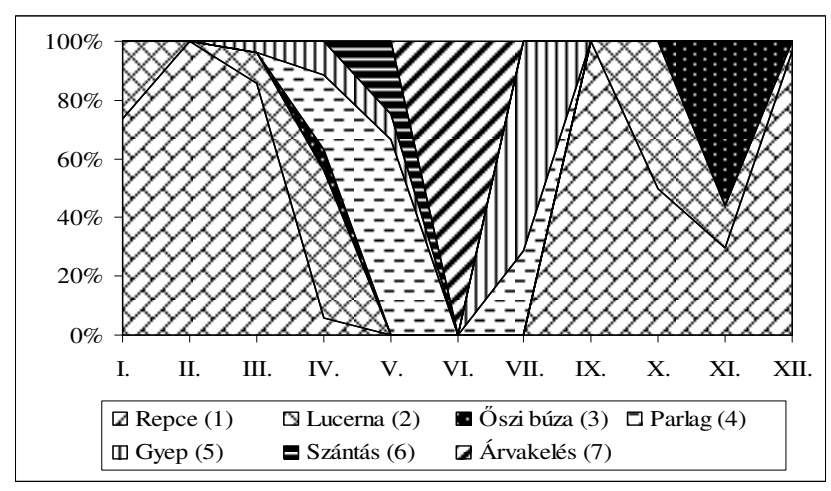

\section{6. ábra: A túzok élőhelyhasználata Dévaványán (2006)}

Figure 86: Habitat use of the Great Bustard in Dévaványa (2006)

(1) Rape, (2) Alfalfa, (3) Winter wheat, (4) Fallow, (5) Grassland, (6) Ploughed field, (7) Volunteer crop

A túzok élőhely választása (IvLEV-index alapján) a dévaványai területen áprilisban a lucernkra, a parlagokra, valamint a repcére koncentrált. Augusztusban nem figyeltünk meg túzokokat a monitoring területen, így a nyári élőhelyválasztásról nincs adatunk 2006-ban. Télen a fajra jellemzően a repce magas preferenciáját tapasztaltuk (87. ábra).

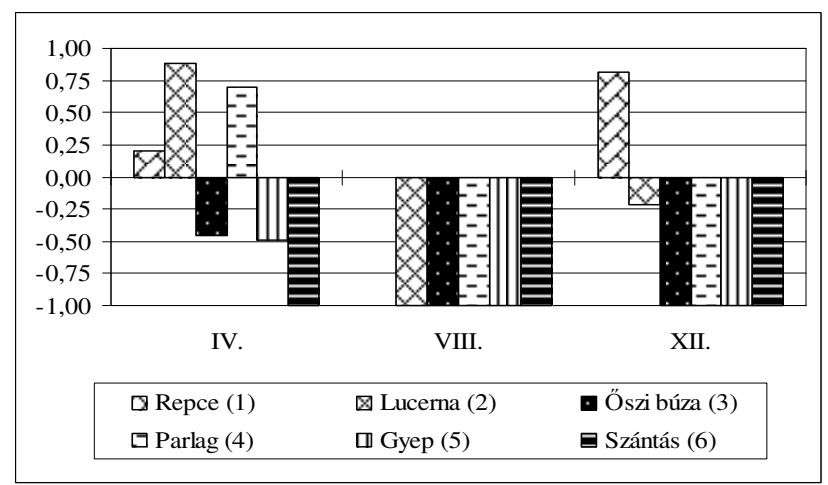

87. ábra: A túzok élőhelyválasztása (IVLEV index) Dévaványán (2006)

Figure 87: IVLEV's electivity index of Great Bustard in Dévaványa (2006)

(1) Rape, (2) Alfalfa, (3) Winter wheat, (4) Fallow, (5) Grassland, (6) Ploughed field 
A monitoringterület fészkelési szempontú minősítése 60,76\%-os eredményt adott 2006-ban, ami átlagosnak tekinthető (31. táblázat). A térségben megtalált 30 fészekből 4 került elő erről a területről, árpa, búza, illetve gyep élőhelyen. A négy fészekaljból 3 esetben sikeresen kikelt 2 csibe, 1 kaszálás miatt elpusztult.

\section{1. táblázat: Dévaványa élőhelyeinek minősítése tavasszal (2006)}

Table 31: Qualification of habitats of Dévaványa in spring (2006)

\begin{tabular}{|l|c|c|c|}
\hline \multicolumn{1}{|c|}{ Élöhely / Habitat } & $\begin{array}{c}\text { Terület } \\
\text { /Area \% }\end{array}$ & $\begin{array}{c}\text { Kategória } \\
\text { /Category }\end{array}$ & $\begin{array}{c}\text { Red. terület } \\
\text { /Red.area \% }\end{array}$ \\
\hline Gyep/grassland & $33,60 \%$ & 5 & $33,60 \%$ \\
\hline Szántás/ploughed field & $21,82 \%$ & 1 & $0,00 \%$ \\
\hline Öszi kalászos/winter cereals & $19,68 \%$ & 5 & $19,68 \%$ \\
\hline Tárcsázott föld/dialed field & $13,22 \%$ & 1 & $0,00 \%$ \\
\hline Ugar/follow & $4,58 \%$ & 5 & $4,58 \%$ \\
\hline Repce/rape & $3,86 \%$ & 4 & $2,89 \%$ \\
\hline Lucerna/alfalfa & $2,93 \%$ & 1 & $0,00 \%$ \\
\hline Erdő/forest & $0,30 \%$ & 1 & $0,00 \%$ \\
\hline Összesen / Total & $\mathbf{1 0 0 , 0 0 \%}$ & & $\mathbf{6 0 , 7 6 \%}$ \\
\hline
\end{tabular}

\subsection{A túzok élőhelyhasználata és választása Dévaványán 2007-ben}

A dévaványai monitoring területet a gyepterületek állandó aránya mellett változatos, mozaikos mezőgazdasági élőhelyek jellemzték 2007-ben is. A tavaszi időszakban ezen élőhelyek nagy része őszi gabona, repce, lucerna volt. A nyári hónapokban a szántások aránya jelentősen megnőtt, mivel a mezőgazdasági kultúrákat learatták, a területek nagy részén augusztus hónapban szántásokat találtunk. Emellett a tavaszi szántások helyét napraforgó foglalta el. Decemberben tovább nőtt a szántások területi részesedése, ugyanakkor több korábbi szántás helyét repcetáblák foglalták el (88. ábra).

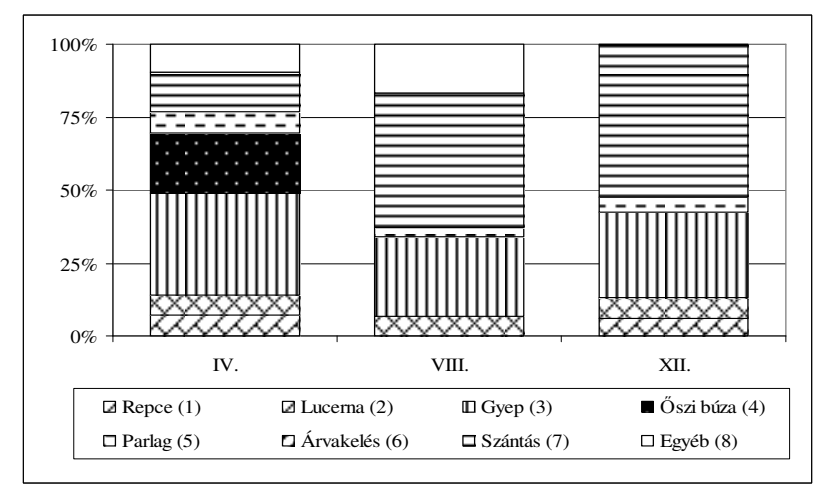

\section{8. ábra: A dévaványai monitoring terület élőhelykínálata (2007)}

Figure 88: Habitat availability in Dévaványa (2007)

(1) Rape (2) Alfalfa, (3) Grassland, (4) Winter wheat, (5) Fallow,

(6) Volunteer-crop, (7) Ploughed field, (8) Other

A túzok élőhelyhasználatát a dévaványai területen a változatosság jellemezte. Nem volt egész évet meghatározóan használt élőhelytípus. A téli hónapokban a repcét, tavasszal és ősz végén a gyepeket, a nyár végi hónapokban a lucernát használták legnagyobb arányban a madarak. Emellett június hónapban a parlagterületek bizonyultak fontos élőhelynek (89. ábra). 


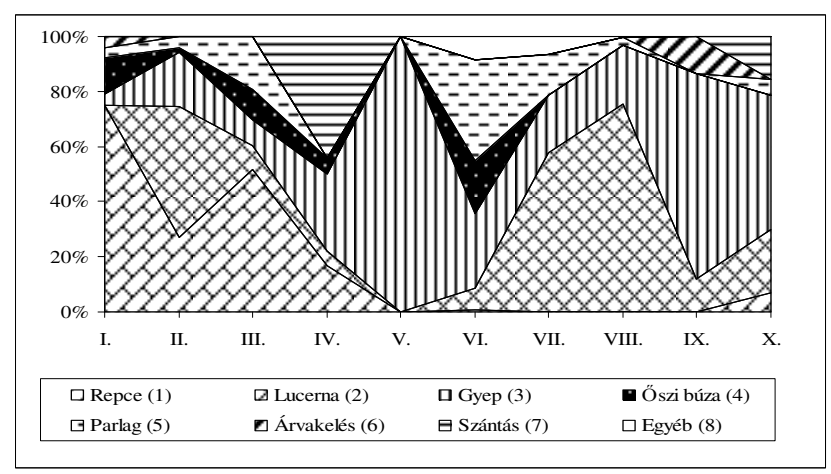

89. ábra: A túzok élőhelyhasználata Dévaványán (2007)

Figure 89: Habitat use of the Great Bustard in Dévaványa (2007) (1) Rape (2) Alfalfa, (3) Grassland, (4) Winter wheat, (5) Fallow,

(6) Volunteer-crop, (7) Ploughed field, (8) Other

Preferált élőhelyeknek tavasszal a repcéket és szántásokat, nyáron a lucernákat, télen (2008. január-február) pedig a repcéket és a gyepeket találtuk (90. ábra).

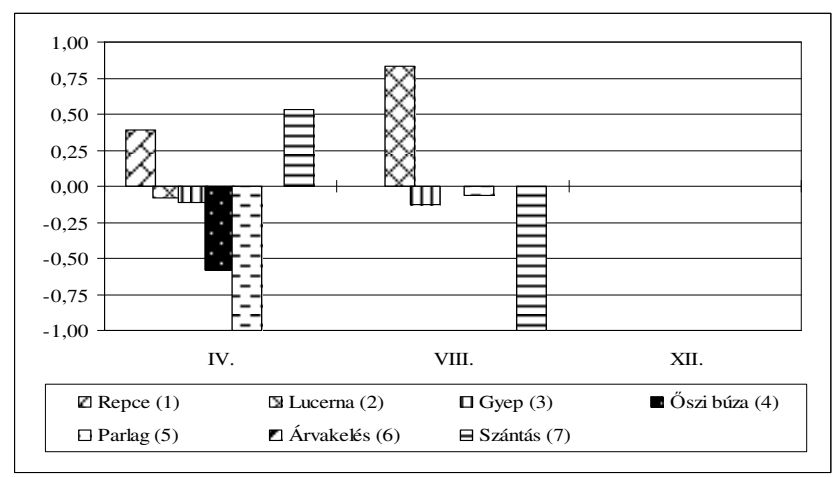

90. ábra: A túzok élőhelyválasztása (IVLEV index) Dévaványán (2007)

Figure 90: IVLEV's electivity index of Great Bustard in Dévaványa (2007)

(1) Rape (2) Alfalfa, (3) Grassland, (4) Winter wheat, (5) Fallow,

(6) Volunteer-crop, (7) Ploughed field, (8) Other

A monitoring terület tavaszi, fészkelési szempontból végzett minősítése 68,63\%-os értéket eredményezett (32. táblázat). Ez 8\%-os növekedés a 2006-os értékekhez képest, ami elsősorban az ugar- és gyepterületek, valamint az őszi kalászosok magas arányának volt köszönhető.

32. táblázat: A dévaványai élőhelyek minősítése tavasszal (2007)

Table 32: Qualification of habitats of the Dévaványa area in spring (2007)

\begin{tabular}{|l|c|c|c|}
\hline \multicolumn{1}{|c|}{ Élőhely / Habitat } & $\begin{array}{c}\text { Terïlet } \\
\text { /Area \% }\end{array}$ & $\begin{array}{c}\text { Kategória } \\
\text { /Category }\end{array}$ & $\begin{array}{c}\text { Red. terület } \\
\text { /Red.area \% }\end{array}$ \\
\hline Gyep/grassland & $34,91 \%$ & 5 & $34,91 \%$ \\
\hline Szántás/ploughed field & $13,46 \%$ & 1 & $0,00 \%$ \\
\hline Öszi kalászos/winter cereals & $20,84 \%$ & 5 & $20,84 \%$ \\
\hline Fénymag/canary grass & $8,82 \%$ & 1 & $0,00 \%$ \\
\hline Ugar/set-aside & $7,38 \%$ & 5 & $7,38 \%$ \\
\hline Repce/rape & $7,33 \%$ & 4 & $5,50 \%$ \\
\hline Lucerna/alfalfa & $6,51 \%$ & 1 & $0,00 \%$ \\
\hline Egyéb/other & $0,75 \%$ & 1 & $0,00 \%$ \\
\hline Összesen / Total & $\mathbf{1 0 0 , 0 0 \%}$ & & $\mathbf{6 8 , 6 3 \%}$ \\
\hline
\end{tabular}




\subsection{A túzok élőhelyhasználata és választása Dévaványán 2008-ban}

A dévaványai monitoring terület 2008 tavaszán (április) hasonló képet mutatott, mint az előző év tavaszán. Az őszi kalászosok és szántások helyzete és aránya változott meg néhány esetben, emellett a gyepek aránya is csökkent 10\%-al (91. ábra).

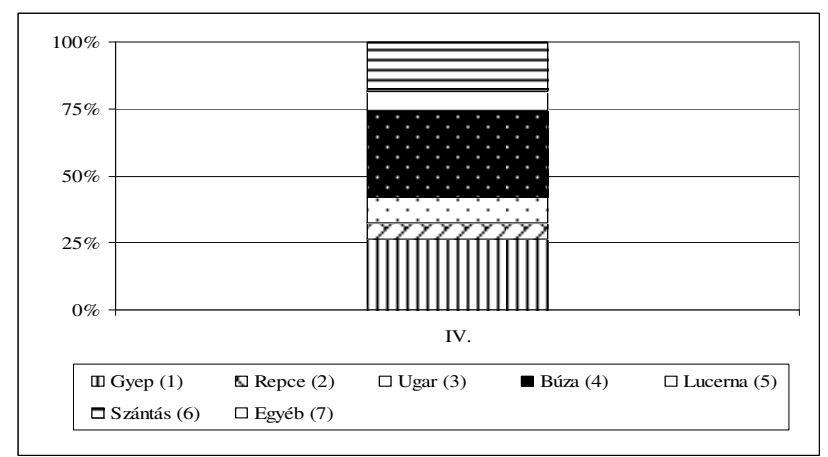

91. ábra: A Dévaványai monitoring terület élőhelykínálata (2008)

Figure 91: Habitat availability in Dévaványa (2008)

(1) Grassland, (2) Rape, (3) Set-aside, (4) Wheat, (5) Alfalfa,

(6) Ploughed field, (7) Other

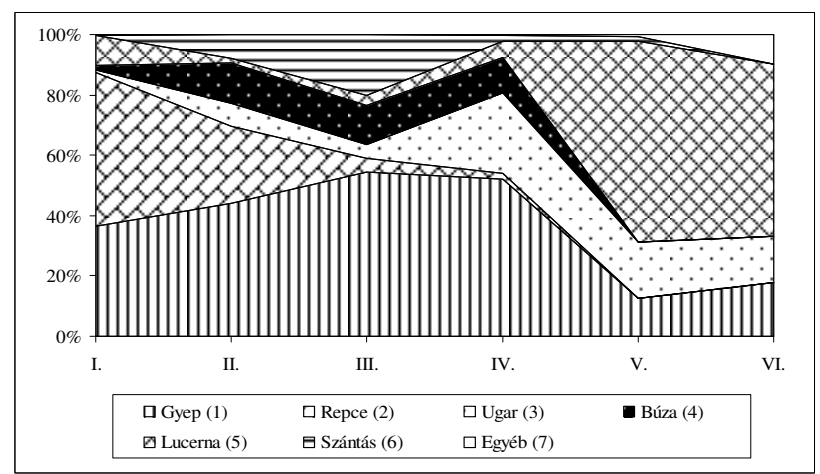

92. ábra: A túzok élőhelyhasználata Dévaványán (2008)

Figure 92: Habitat use of the Great Bustard in Dévaványa (2008)

(1) Grassland, (2) Rape, (3) Set-aside, (4) Wheat, (5) Alfalfa, (6) Ploughed field, (7) Other

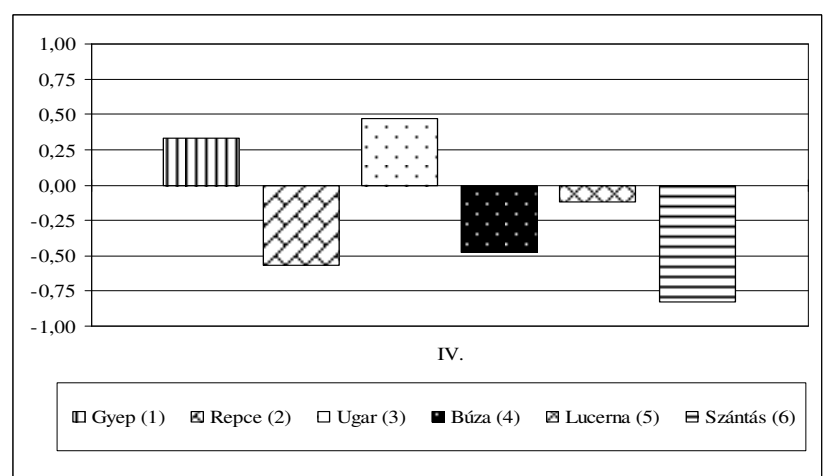

93. ábra: A túzok élőhelyválasztása (IVLEV index) Dévaványán (2008)

Figure 93: IVLEV's electivity index of Great Bustard in Dévaványa (2008)

(1) Grassland, (2) Rape, (3) Set-aside, (4) Wheat, (5) Alfalfa, (6) Ploughed field 
A túzok élőhelyhasználatát a gyepek dominanciája mellett a téli hónapokban a repce, tavasszal az őszi búza és ugarok, nyár elején pedig a lucerna használata jellemezte (92. ábra). Az élőhelyválasztás tavasszal a gyepek és ugarok preferenciáját mutatta (93. ábra).

A monitoring terület tavaszi élőhely jóság szerinti minősítési értéke 72,97\%-ra növekedett az előző évhez képest, köszönhetően az 5-ös értékkel jellemzett gyepek, az őszi gabonák és ugarterületek megnövekedett arányának (33. táblázat).

33. táblázat: A dévaványai élőhelyek minősítése tavasszal (2008)

Table 33: Qualification of habitats of the Dévaványa area in spring (2008)

\begin{tabular}{|l|c|c|c|}
\hline \multicolumn{1}{|c|}{ Élőhely / Habitat } & $\begin{array}{c}\text { Terület } \\
\text { /Area \% }\end{array}$ & $\begin{array}{c}\text { Kategória } \\
\text { /Category }\end{array}$ & $\begin{array}{c}\text { Red. terület } \\
\text { /Red.area \% }\end{array}$ \\
\hline Gyep/grassland & $26,24 \%$ & 5 & $26,24 \%$ \\
\hline Szántás/ploughed field & $18,12 \%$ & 1 & $0,00 \%$ \\
\hline Öszi kalászos/winter cereals & $32,50 \%$ & 5 & $32,50 \%$ \\
\hline Ugar/set-aside & $9,61 \%$ & 5 & $9,61 \%$ \\
\hline Repce/rape & $6,16 \%$ & 4 & $4,62 \%$ \\
\hline Lucerna/alfalfa & $7,10 \%$ & 1 & $0,00 \%$ \\
\hline Egyéb/other & $0,27 \%$ & 1 & $0,00 \%$ \\
\hline Összesen / Total & $\mathbf{1 0 0 , 0 0 \%}$ & & $\mathbf{7 2 , 9 7 \%}$ \\
\hline
\end{tabular}

\section{KIS-SÁRRÉT}

\subsection{A túzok élőhelyhasználata és választása a Kis-Sárréten 2005-ben}

A Kis-Sárrét területét a gyep jellegü élőhelyek egész évben közel 50\%-ban borították, amely igen kedvezőnek bizonyult a túzokállomány szempontjából. A gyepek mellett a lucerna mindhárom vizsgált időszakban közel 10\%-át, a szántások tavasszal és télen további 10-14\%át adták a terület élőhelykínálatának (94. ábra).

A túzok élőhelyhasználatát (95. ábra) elemezve megállapíthattuk, hogy a Kis-Sárréten szinte kizárólag gyepeken jelentek meg a túzokok. Kivétel ezalól a novemberben több alkalommal észlelt 18 kakas volt, amelyek minden megfigyelés alkalmával repcén tartózkodtak. A márciusban megfigyelt egyedek emellett lucernán $(10 \%)$ fordultak elő.

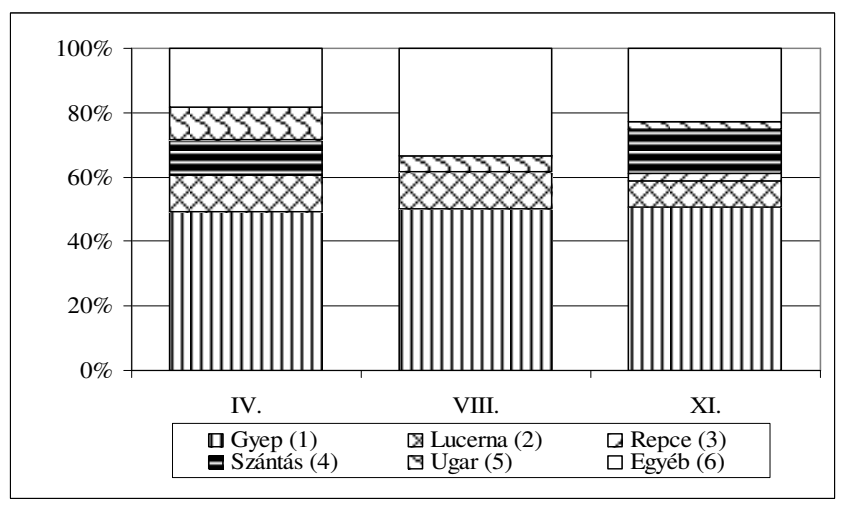

94. ábra: A Kis-Sárrét élőhelykínálata (2005)

Figure 94: Habitat availability of the Kis-Sárrét (2005)

(1) Grassland, (2) Alfalfa, (3) Rape, (4) Ploughed field, (5) Set-aside, (6) Other 


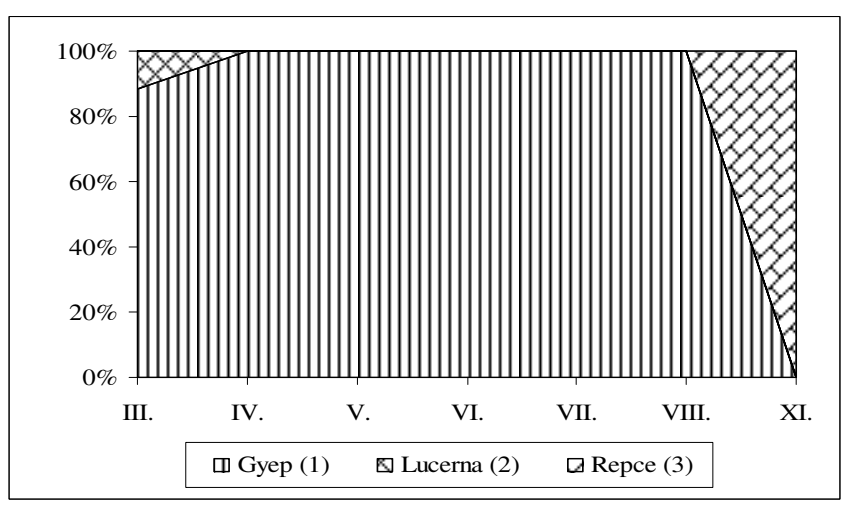

\section{5. ábra: A túzok élőhelyhasználata a Kis-Sárréten (2005)}

Figure 95: Habitat use of the Great Bustard in the Kis-Sárrét (2005)

(1) Grassland, (2) Alfalfa, (3) Rape

Az élőhely-preferenciát kifejező Ivlev-indexek (96. ábra) is megerősítették, hogy a tavaszi valamint nyári időszakban a gyepek voltak a kedvelt élőhelyek, míg novemberben a repce preferenciáját tapasztalhattuk.

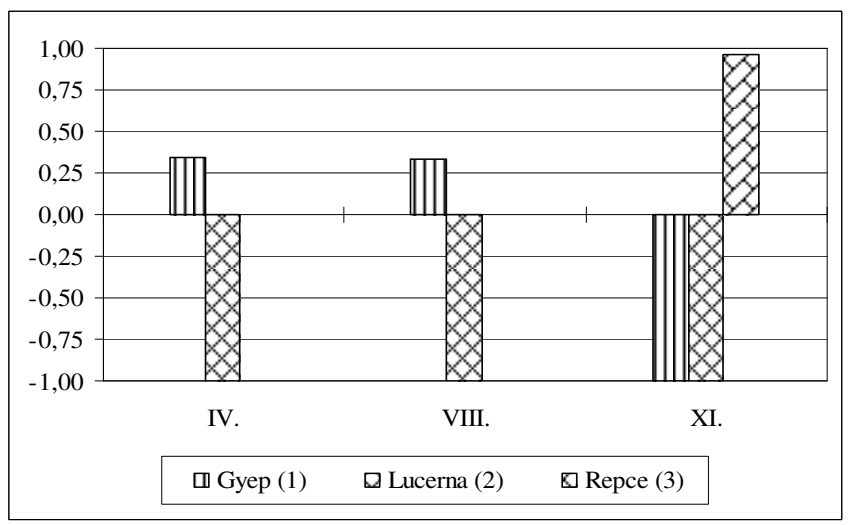

96. ábra: A túzok élőhelyválasztása (IVLEV-index) a Kis-Sárréten (2005)

Figure 96: IVLEV's electivity index of Great Bustard in the Kis-Sárrét (2005)

(1) Grassland, (2) Alfalfa, (3) Rape

A fészkelési időszakban a Kis-Sárrét élőhely minősítése igen magas, 73,35\%-os értéket kapott (34. táblázat), köszönhetően az 5-ös kategóriába sorolt gyep, búza és ugar magas arányának a területen.

34. táblázat: A Kis-Sárrét élőhelyeinek minősítése tavasszal (2005)

Table 34: Qualification of habitats of the Kis-Sárrét in spring (2005)

\begin{tabular}{|l|c|c|c|}
\hline \multicolumn{1}{|c|}{ Élöhely / Habitat } & $\begin{array}{c}\text { Terület } \\
\text { /Area \% }\end{array}$ & $\begin{array}{c}\text { Kategória } \\
\text { /Category }\end{array}$ & $\begin{array}{c}\text { Red. terület } \\
\text { /Red.area \% }\end{array}$ \\
\hline Búza/winter wheat & $9,32 \%$ & 5 & $9,32 \%$ \\
\hline Erdö/forest & $4,19 \%$ & 1 & $0,00 \%$ \\
\hline Gyep/grassland & $49,23 \%$ & 5 & $49,23 \%$ \\
\hline Parlag/fallow & $4,57 \%$ & 5 & $4,57 \%$ \\
\hline Lucerna/alfalfa & $11,67 \%$ & 1 & $0,00 \%$ \\
\hline Szántás/ploughed field & $10,98 \%$ & 1 & $0,00 \%$ \\
\hline Ugar/Set-aside & $9,85 \%$ & 5 & $9,85 \%$ \\
\hline Zab/oat & $0,19 \%$ & 5 & $0,19 \%$ \\
\hline Összesen / Total & $\mathbf{1 0 0 , 0 0 \%}$ & & $\mathbf{7 3 , 1 6 \%}$ \\
\hline
\end{tabular}




\subsection{A túzok élőhelyhasználata és választása Kis-Sárréten 2006-ban}

A Kis-Sárrét területének nagy részét (több mint 50\%-át) az év egészében a gyepek jellemzik (97. ábra). A gyepek mellett mozaikos elhelyezkedésű mezőgazdasági élőhelyek jellemzték a térséget. Szántókon elsősorban őszi búzát, lucernát találhattunk, a repce azonban hiányzott a területről.

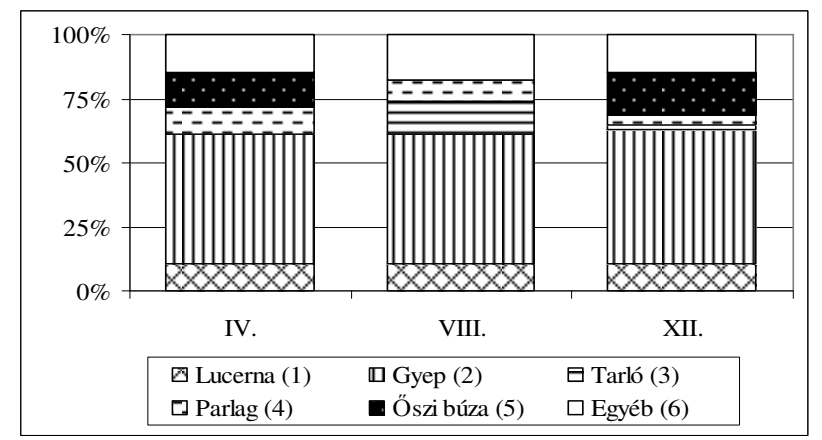

97. ábra: A Kis-Sárrét monitoring terület élőhelykínálata (2006)

Figure 97: Habitat availability in the Kis-Sárrét (2006)

(1) Alfalfa, (2) Grassland, (3) Stubble, (4) Fallow, (5) Winter wheat, (6) Other

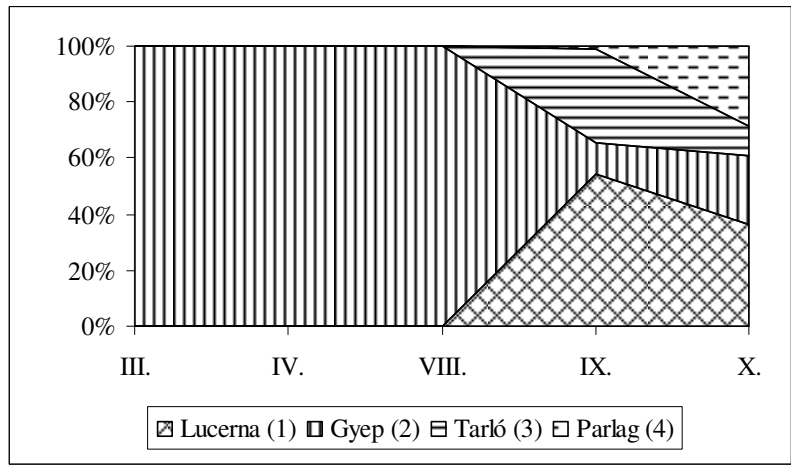

98. ábra: A túzok élőhelyhasználata a Kis-Sárréten (2006)

Figure 98: Habitat use of the Great Bustard in the Kis-Sárrét (2006)

(1) Alfalfa, (2) Grassland, (3) Stubble, (4) Fallow

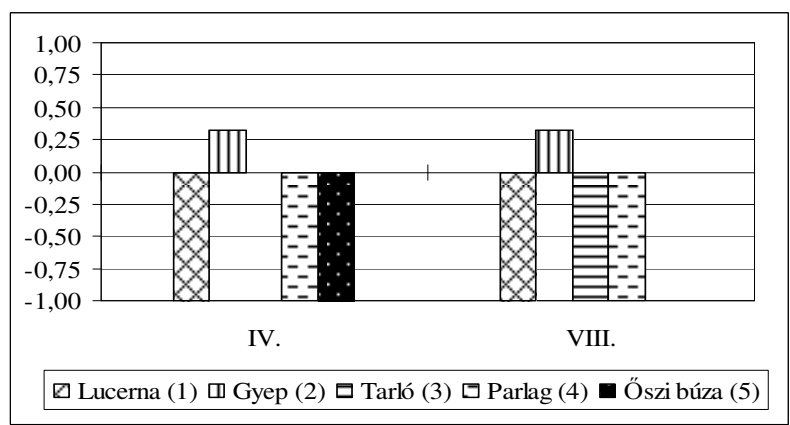

99. ábra: A túzok élőhelyválasztása (IVLEV index) a Kis-Sárréten (2006)

Figure 99: IVLEV's electivity index of Great Bustard in the Kis-Sárrét (2006)

(1) Alfalfa, (2) Grassland, (3) Stubble, (4) Fallow, (5) Winter wheat

A túzok élőhelyhasználatát vizsgálva (98. ábra) láthatjuk, hogy mindössze öt hónapban figyeltük meg a fajt a területen. A túzokok téli elvándorlásának egyik, talán a legfőbb oka pont a repce hiánya lehet, amely az összes monitoring terület által is igazoltan a legkedveltebb téli 
élő- és táplálkozóhelye a túzoknak. Tavasszal és nyáron a Kis-Sárréten szinte kizárólag gyepeken voltak megfigyeltők a túzokok, míg ősszel a lucernát, parlagterületeket is látogatták.

Az IVLEV-index adatok a gyepterületek egyértelmű preferenciáját mutatták (99. ábra). Télen nem figyeltünk meg túzokot a Kis-Sárréten, így ebből az évszakban élőhelyválasztási értékeket nem tudtunk számítani.

A terület tavaszi, fészkelési szempontú minősítése (35. táblázat) 80,58\%-os értéket eredményezett, amely a legmagasabb volt a hazai túzokvédelmi területek között 2006-ban. Ennek egyik oka a terület kis mérete, a gyepek, búza-táblák és ugar-területek magas aránya.

35. táblázat: A Kis-Sárrét élőhelyeinek minősítése tavasszal (2006)

Table 35: Qualification of habitats of the Kis-Sárrét in spring (2006)

\begin{tabular}{|l|c|c|c|}
\hline \multicolumn{1}{|c|}{ Élőhely / Habitat } & $\begin{array}{c}\text { Terület } \\
\text { /Area \% }\end{array}$ & $\begin{array}{c}\text { Kategória } \\
\text { /Category }\end{array}$ & $\begin{array}{c}\text { Red. terület } \\
\text { /Red.area \% }\end{array}$ \\
\hline Gyep/grassland & 50,86 & 5 & $0,00 \%$ \\
\hline Öszi búza/winter wheat & 13,18 & 5 & $14,73 \%$ \\
\hline Lucerna/alfalfa & 10,52 & 1 & $13,96 \%$ \\
\hline Ugar/set-aside & 14,82 & 5 & $9,22 \%$ \\
\hline Erdő/forest & 4,18 & 1 & $0,00 \%$ \\
\hline Kukorica/maize & 3,45 & 3 & $0,00 \%$ \\
\hline Egyéb/other & 2,99 & 1 & $0,00 \%$ \\
\hline Összesen / Total & $\mathbf{1 0 0 , 0 0 \%}$ & & $\mathbf{8 0 , 5 8 \%}$ \\
\hline
\end{tabular}

\subsection{A túzok élőhelyhasználata és választása a Kis-Sárréten 2007-ben}

A Kis-Sárrétet áprilisi, augusztusi és decemberi hónapokban egyaránt a gyepek magas aránya jellemezte, amely a túzok számára kifejezetten kedvező volt. A korábbi évek egyik negatívuma - a repceterületek hiánya - ebben az évben már nem volt jellemző a Kis-Sárrétre. A repcetáblák áprilisban és decemberben is megtalálhatóak voltak a területen. Az egyes élőhelyek arányait tekinve, a gyepek 52\%-ot fedtek, emellett az őszi búza (15-17\%), a lucerna (3-13\%) aránya volt kiemelkedö. Az említett repce áprilisban a terület 1\%-át, míg decemberben annak 1,8\%-át fedte (100. ábra).

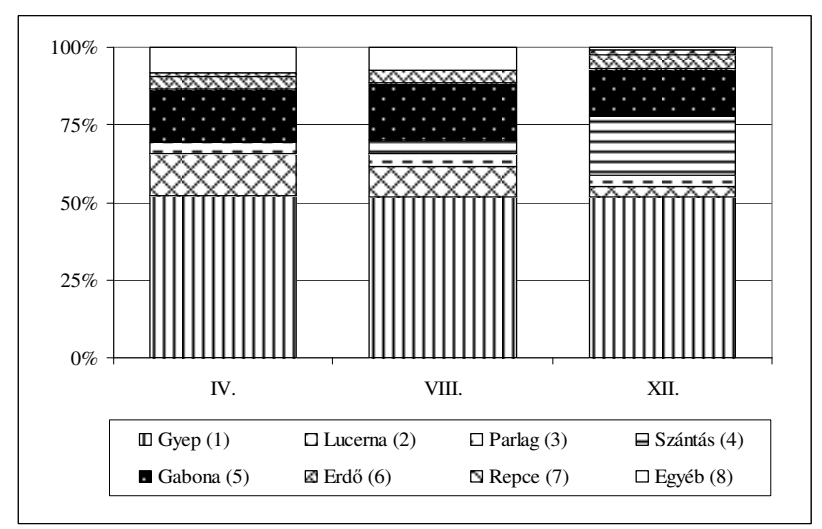

100. ábra: A Kis-Sárréti monitoring terület élőhelykínálata (2007)

Figure 100: Habitat availability in the Kis-Sárrét (2007)

(1) Grassland, (2) Alfalfa, (3) Fallow, (4) Ploughed field, (5) Cereals, (6) Forest, (7) Rape, (8) Other 
Repcetáblán történt túzokmegfigyelések - az élőhelytípus rendelkezésreállásána ellenére 2007-ben még nem történtek, a madarak elsősorban a gyepeket, lucernát és szántásokat látogatták (101. ábra).

Az élőhelyválasztási számítások (IVLEV-index) a három vizsgált hónapban a gyepek és a lucerna preferenciáját mutatták (102. ábra).

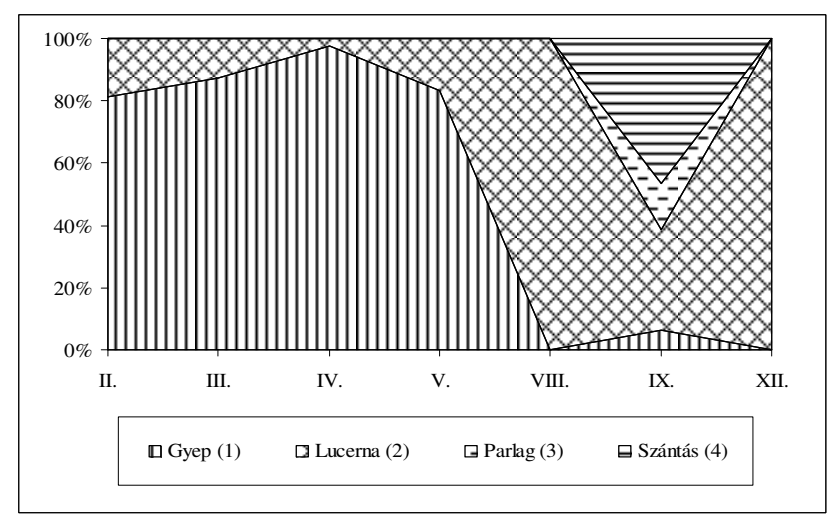

101. ábra: A túzok élőhelyhasználata a Kis-Sárréten (2007)

Figure 101: Habitat use of the Great Bustard Kis-Sárrét (2007)

(1) Grassland, (2) Alfalfa, (3) Fallow, (4) Ploughed field

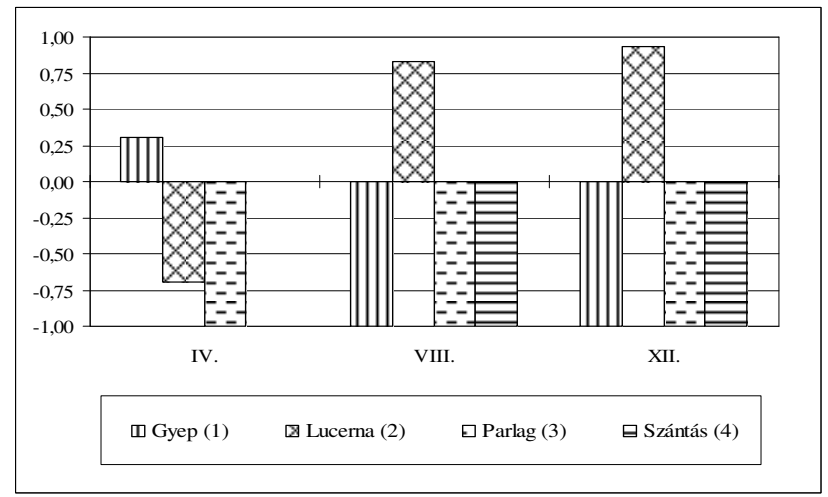

102. ábra: A túzok élőhelyválasztása (IVLEV index) a Kis-Sárréten (2007)

Figure 102: IVLEV's electivity index of Great Bustard in the Kis-Sárrét (2007)

(1) Grassland, (2) Alfalfa, (3) Fallow, (4) Ploughed field

36. táblázat: A Kis-Sárréti élőhelyeinek minősítése tavasszal (2007)

Table 36: Qualification of habitats of the Kis-Sárrét in spring (2007)

\begin{tabular}{|l|c|c|c|}
\hline \multicolumn{1}{|c|}{ Élöhely / Habitat } & $\begin{array}{c}\text { Terület } \\
\text { /Area \% }\end{array}$ & $\begin{array}{c}\text { Kategória } \\
\text { /Category }\end{array}$ & $\begin{array}{c}\text { Red. terület } \\
\text { /Red.area \% }\end{array}$ \\
\hline Gyep/grassland & $52,41 \%$ & 5 & $52,41 \%$ \\
\hline Öszi búza/winter wheat & $17,15 \%$ & 5 & $17,15 \%$ \\
\hline Lucerna/alfalfa & $13,44 \%$ & 1 & $0,00 \%$ \\
\hline Ugar/set-aside & $3,63 \%$ & 5 & $3,63 \%$ \\
\hline Erdö/forest & $4,18 \%$ & 1 & $0,00 \%$ \\
\hline Kukorica/maize & $2,22 \%$ & 3 & $1,11 \%$ \\
\hline Napraforgó/sunflower & $2,67 \%$ & 3 & $1,34 \%$ \\
\hline Egyéb/other & $4,30 \%$ & 1 & $0,00 \%$ \\
\hline Összesen / Total & $\mathbf{1 0 0 , 0 0 \%}$ & & $\mathbf{7 4 , 3 0 \%}$ \\
\hline
\end{tabular}


A monitoringterület fészkelési időszakban végzett minősítése 2007-ben magas értéket eredményezett, 74,3\% lett, köszönhetően elsősorban a kedvezően kezelt gyepek magas arányának (36. táblázat).

\subsection{A túzok élőhelyhasználata és választása a Kis-Sárréten 2008-ban}

A kis-sárréti monitoring terület 2008 áprilisában az állandó méretü gyepektől eltekintve jelentősen különbözött a 2007. áprilisi állapotoktól a szántókon termesztett növényeket tekintve. Ebben az évben ugyanis kukoricát vetettek azokon a területeken, ahol előző évben lucernát, őszi gabonát találtunk. A gyepek részesedése ezúttal is 52\% volt, emellett a kukorica 17\%, őszi búza 9\%, a repce pedig 1,8\%-ot fedett (103. ábra).

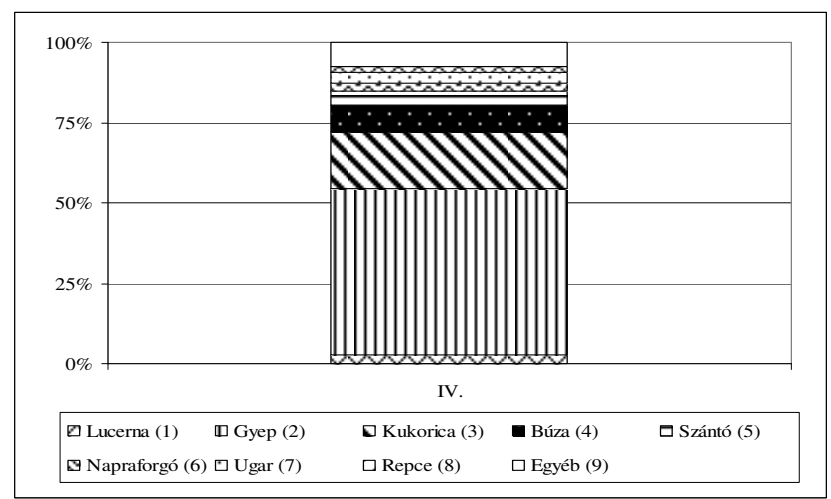

103. ábra: A Kis-Sárréti monitoring terület élőhelykínálata (2008)

Figure 103: Habitat availability in the Kis-Sárrét (2008)

(1) Alfalfa, (2) Grassland, (3) Maize, (4) Wheat,

(5) Ploughed field, (6) Sunflower, (7) Set-aside, (8) Rape, (9) Other

A kis-sárréti túzokok 2008 évi élőhelyhasználatát a gyepek egyértelmü dominanciája jellemezte. Mindössze februárban látogattak egyéb élőhelyet - 13\%-ban lucernán is előfordultak (104. ábra).

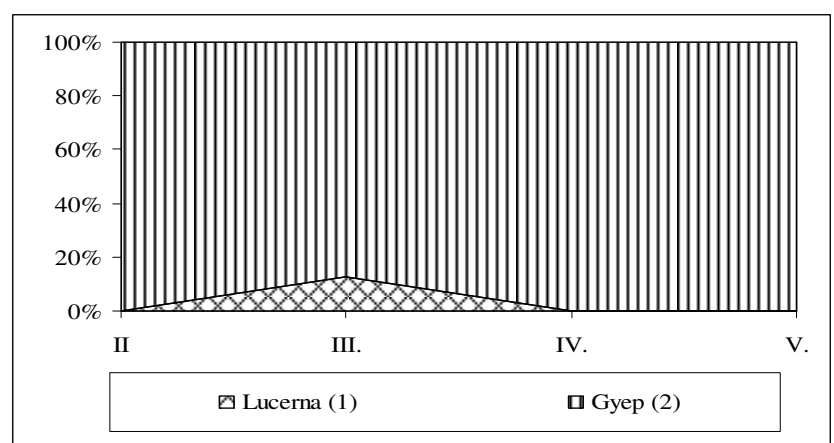

104. ábra: A túzok élőhelyhasználata a Kis-Sárréten (2008)

Figure 104: Habitat use of the Great Bustard in the Kis-Sárrét (2008)

(1) Alfalfa, (2) Grassland

A számított IVLEV-indexek egyértelműen a gyepek preferenciáját mutatták, mivel ebben a hónapban mindössze négy megfigyelés történt, mindegyik gyep élőhelyen (105. ábra).

Az élőhelyek fészkelési szempontból elvégzett minősítése 74,67\%-ot mutatott, amely megegyezett az előző évi értékkel. 


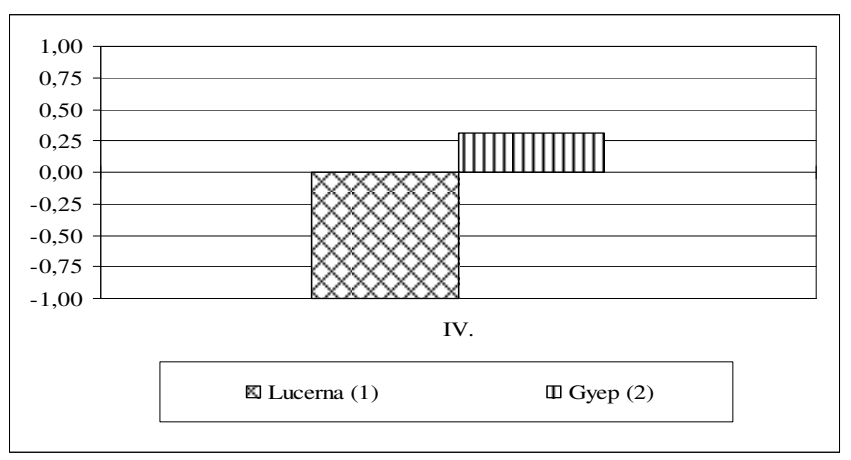

105. ábra: A túzok élőhelyválasztása (IVLEV index) a Kis-Sárréten (2008)

Figure 105: IVLEV's electivity index of Great Bustard in the Kis-Sárrét (2008)

(1) Alfalfa, (2) Grassland

37. táblázat: A Kis-Sárrét élőhelyeinek minősítése tavasszal (2008)

Table 37: Qualification of habitats of the Kis-Sárrét in spring (2008)

\begin{tabular}{|l|c|c|c|}
\hline \multicolumn{1}{|c|}{ Élőhely / Habitat } & $\begin{array}{c}\text { Terület } \\
\text { /Area \% }\end{array}$ & $\begin{array}{c}\text { Kategória } \\
\text { /Category }\end{array}$ & $\begin{array}{c}\text { Red. terület } \\
\text { /Red.area \% }\end{array}$ \\
\hline Gyep/grassland & $51,99 \%$ & 5 & $51,99 \%$ \\
\hline Öszi búza/winter wheat & $8,11 \%$ & 5 & $8,11 \%$ \\
\hline Lucerna/alfalfa & $2,65 \%$ & 1 & $0,00 \%$ \\
\hline Ugar/set-aside & $3,45 \%$ & 5 & $3,45 \%$ \\
\hline Erdő/forest & $4,18 \%$ & 1 & $0,00 \%$ \\
\hline Kukorica/maize & $17,45 \%$ & 3 & $8,73 \%$ \\
\hline Napraforgó/sunflower & $2,13 \%$ & 3 & $1,07 \%$ \\
\hline Repce/rape & $1,77 \%$ & 4 & $1,33 \%$ \\
\hline Szántás/ploughed field & $4,75 \%$ & 1 & $0,00 \%$ \\
\hline Egyéb/other & $3,52 \%$ & 1 & $0,00 \%$ \\
\hline Összesen / Total & $\mathbf{1 0 0 , 0 0 \%}$ & \multicolumn{2}{|c}{} \\
\hline
\end{tabular}

\section{A TÚZOK ÉLŐHELYVÁLASZTÁSÁNAK TERÜLETI ÉS SZEZONÁLIS ÖSSZEHASONLÍTÁSA}

A túzok élőhelyválasztását elemezve nagyon erős hasonlóságok mutathatók ki az egyes vizsgált területeink között (38-46. táblázat). A prefereált élőhelyek minden területen és minden évben ugyanazok voltak, aminek határozott üzenetei és lehetőségei vannak a természetvédelem számára. Területenként ezek az élőhelyek az alábbiak voltak:

Mosoni-sík: ugar (6), repce (4), tarló (2), gyep (2), árvakelés (1)

Kiskunság: lucerna (7), repce (6), parlag (6), őszi búza (3), szántás (3), tarló (3), kukorica (1)

Solti-sík: gyep (5), tarló (4), lucerna (3), repce (3), őszi búza (2), őszi árpa (1), napraforgó (1), árvakelés (1)

Hevesi-sík: lucerna (7), repce (5), gyep (4), őszi gabona (2), tarló (1), parlag (2), szántás (1)

Borsodi-Mezőség: gyep (4), repce (3), lucerna (3), szántás (1)

Hortobágy: repce (7), lucerna (7), őszi búza (4), parlag (2), gyep (1), tarló (2), árvakelés (1)

Bihari-sík: gyep (8), lucerna (7), repce (4), gabona (2), mezsgye (1), szántás (1), ugar (2)

Dévaványa: repce (6), lucerna (4), őszi búza (1), gyep (2), napraforgó (1), szántás (3), parlag (2)

Kis-Sárrét: gyep (6), lucerna (3) 


\section{8. táblázat: A túzok élőhelypreferencia-értékei a Mosoni-síkon (2005-2008)}

Table 38: Habitat selection values of Great Bustard in the Mosoni-plain (2005-2008)

\begin{tabular}{|l|c|c|c|c|c|c|c|c|c|}
\hline \multirow{2}{*}{$\begin{array}{c}\text { Élőhelytípus } \\
\text { Habitat }\end{array}$} & \multicolumn{3}{|c|}{$\mathbf{2 0 0 5 / 2 0 0 6}$} & \multicolumn{3}{c|}{$\mathbf{2 0 0 6 / 2 0 0 7}$} & \multicolumn{3}{c|}{ 2007/2008 } \\
\cline { 2 - 10 } & $\mathrm{Ta} / \mathrm{S}$ & $\mathrm{Ny} / \mathrm{Su}$ & $\mathrm{Té} / \mathrm{W}$ & $\mathrm{Ta} / \mathrm{S}$ & $\mathrm{Ny} / \mathrm{Su}$ & $\mathrm{Té} / \mathrm{W}$ & $\mathrm{Ta} / \mathrm{S}$ & $\mathrm{Ny} / \mathrm{Su}$ & $\mathrm{T} / \mathrm{W}$ \\
\hline Ugar (1) & $\mathbf{0 , 8 4}$ & $\mathbf{0 , 8 3}$ & $-0,98$ & $\mathbf{0 , 7 7}$ & $\mathbf{0 , 4 2}$ & $-1,00$ & $\mathbf{0 , 7 8}$ & $\mathbf{0 , 7 7}$ & $-0,65$ \\
\hline Repce (2) & $-0,76$ & 0,00 & $\mathbf{0 , 8 6}$ & $\mathbf{0 , 5 2}$ & 0,00 & $\mathbf{0 , 7 7}$ & $-0,13$ & 0,00 & $\mathbf{0 , 7 7}$ \\
\hline Árvakelés (3) & $-1,00$ & $-1,00$ & $-1,00$ & 0,00 & $-0,12$ & 0,00 & $\mathbf{0 , 8 6}$ & $-0,46$ & $-0,90$ \\
\hline Öszi búza (4) & $-0,38$ & 0,00 & $-0,71$ & - & - & - & $-0,60$ & 0,00 & $-0,98$ \\
\hline Tarló (5) & $-1,00$ & $-0,37$ & $-1,00$ & $-1,00$ & $\mathbf{0 , 2 6}$ & $\mathbf{0 , 1 1}$ & 0,00 & $-0,18$ & 0,00 \\
\hline Szántás (6) & $-1,00$ & $-1,00$ & $-1,00$ & $-0,74$ & $-0,96$ & $-0,77$ & $-0,64$ & $-0,56$ & $-0,73$ \\
\hline Gyep (7) & - & - & - & $\mathbf{0 , 6 2}$ & $\mathbf{0 , 2 2}$ & $-1,00$ & - & - & - \\
\hline Lucerna (8) & - & - & - & $-0,15$ & 0,08 & $-1,00$ & $-0,67$ & $-0,75$ & $\mathbf{0 , 0 9}$ \\
\hline
\end{tabular}

1.) set-aside, 2.) rape, 3.) volunteer crop, 4.) winter wheat, 5.) stubble, 6.) plowing, 7.) grassland, 8.) alfalfa $\mathrm{S}=$ Spring; $\mathrm{Su}=$ Summer; $\mathrm{W}=$ Winter

39. táblázat: A túzok élőhelypreferencia-értékei a Kiskunságban (2005-2008)

Table 39: Habitat selection values of Great Bustard in Kiskunság (2005-2008)

\begin{tabular}{|l|c|c|c|c|c|c|c|c|c|}
\hline \multirow{2}{*}{$\begin{array}{c}\text { Élöhelytípus } \\
\text { Habitat }\end{array}$} & \multicolumn{3}{|c|}{$\mathbf{2 0 0 5 / 2 0 0 6}$} & \multicolumn{3}{c|}{$\mathbf{2 0 0 6 / 2 0 0 7}$} & \multicolumn{3}{c|}{$\mathbf{2 0 0 7 / 2 0 0 8}$} \\
\cline { 2 - 10 } & $\mathrm{Ta} / \mathrm{S}$ & $\mathrm{Ny} / \mathrm{Su}$ & $\mathrm{T} / \mathrm{W}$ & $\mathrm{Ta} / \mathrm{S}$ & $\mathrm{Ny} / \mathrm{Su}$ & $\mathrm{T} e ́ / \mathrm{W}$ & $\mathrm{Ta} / \mathrm{S}$ & $\mathrm{Ny} / \mathrm{Su}$ & $\mathrm{T} e ́ / \mathrm{W}$ \\
\hline Repce (1) & $\mathbf{0 , 9 7}$ & $-1,00$ & $\mathbf{0 , 9 1}$ & $\mathbf{0 , 8 3}$ & 0,00 & $\mathbf{0 , 8 5}$ & $\mathbf{0 , 4 5}$ & 0,00 & $\mathbf{0 , 9 0}$ \\
\hline Parlag (2) & $\mathbf{0 , 4 7}$ & $\mathbf{0 , 5 1}$ & $-0,97$ & $\mathbf{0 , 0 6}$ & $-0,47$ & $-0,49$ & $\mathbf{0 , 0 6}$ & $\mathbf{0 , 1 3}$ & $\mathbf{0 , 2 1}$ \\
\hline Lucerna (3) & $\mathbf{0 , 2 7}$ & $\mathbf{0 , 6 9}$ & 0,00 & $\mathbf{0 , 4 0}$ & $\mathbf{0 , 5 1}$ & $\mathbf{0 , 2 8}$ & $\mathbf{0 , 4 1}$ & $\mathbf{0 , 3 9}$ & $-0,27$ \\
\hline Gyep (4) & $-0,46$ & $-0,55$ & $-0,44$ & $-0,33$ & $-0,51$ & $-0,72$ & $-0,28$ & $-0,28$ & $-0,72$ \\
\hline Öszi búza (5) & $-0,21$ & $\mathbf{1 , 0 0}$ & $-1,00$ & - & - & - & $\mathbf{0 , 4 3}$ & $\mathbf{1 , 0 0}$ & $-0,36$ \\
\hline Szántás (6) & $-1,00$ & $\mathbf{0 , 4 8}$ & $\mathbf{0 , 3 4}$ & $-0,92$ & $\mathbf{0 , 4 2}$ & $-0,41$ & $-0,96$ & $-0,17$ & $-0,95$ \\
\hline Tarló (7) & - & - & - & $\mathbf{0 , 1 2}$ & $\mathbf{0 , 5 5}$ & $-1,00$ & $-0,69$ & $\mathbf{0 , 7 1}$ & $-0,79$ \\
\hline Kukorica (8) & - & - & - & $\mathbf{1 , 0 0}$ & 0,00 & 0,00 & - & - & - \\
\hline
\end{tabular}

1.) rape, 2.) fallow, 3.) alfalfa, 4.) grassland 5.) winter wheat, 6.) plowing, 7.) stubble, 8.) maize $\mathrm{S}=$ Spring; $\mathrm{Su}=$ Summer; $\mathrm{W}=$ Winter

\section{0. táblázat: A túzok élőhelypreferencia-értékei a Solti-síkon (2005-2008)}

Table 40: Habitat selection values of Great Bustard in Solti-plain (2005-2008)

\begin{tabular}{|l|c|c|c|c|c|c|c|c|c|}
\hline \multirow{2}{*}{$\begin{array}{c}\text { Élőhelytípus } \\
\text { Habitat }\end{array}$} & \multicolumn{3}{|c|}{$\mathbf{2 0 0 5 / 2 0 0 6}$} & \multicolumn{3}{c|}{$\mathbf{2 0 0 6 / 2 0 0 7}$} & \multicolumn{3}{c|}{$\mathbf{2 0 0 7 / 2 0 0 8}$} \\
\cline { 2 - 11 } & $\mathrm{Ta} / \mathrm{S}$ & $\mathrm{Ny} / \mathrm{Su}$ & $\mathrm{Té} / \mathrm{W}$ & $\mathrm{Ta} / \mathrm{S}$ & $\mathrm{Ny} / \mathrm{Su}$ & $\mathrm{T} e ́ / \mathrm{W}$ & $\mathrm{T} / \mathrm{S}$ & $\mathrm{Ny} / \mathrm{Su}$ & $\mathrm{T} / \mathrm{W}$ \\
\hline Repce (1) & $-1,00$ & $-1,00$ & $\mathbf{0 , 8 7}$ & $-0,47$ & 0,00 & $\mathbf{0 , 7 5}$ & $-1,00$ & 0,00 & $\mathbf{0 , 9 2}$ \\
\hline Gyep (2) & $\mathbf{0 , 1 0}$ & $\mathbf{0 , 2 4}$ & $-0,57$ & $-0,27$ & $-0,23$ & $\mathbf{0 , 3 4}$ & $\mathbf{0 , 3 1}$ & $\mathbf{0 , 0 7}$ & $-0,82$ \\
\hline Tarló (3) & 0,00 & $\mathbf{1 , 0 0}$ & $-1,00$ & $\mathbf{1 , 0 0}$ & $\mathbf{0 , 2 9}$ & 0,00 & 0,00 & $\mathbf{0 , 4 2}$ & 0,00 \\
\hline Öszi árpa (4) & $\mathbf{0 , 6 5}$ & $-1,00$ & 0,00 & - & - & - & - & - & - \\
\hline Öszi búza (5) & $\mathbf{0 , 1 7}$ & $-1,00$ & $-0,25$ & $-0,18$ & 0,00 & $-0,44$ & $\mathbf{0 , 0 2}$ & 0,00 & $-0,34$ \\
\hline Napraforgó (6) & $\mathbf{1 , 0 0}$ & $-1,00$ & 0,00 & - & - & - & - & - & - \\
\hline Lucerna (7) & - & - & - & $\mathbf{0 , 5 3}$ & $-0,19$ & $-1,00$ & $\mathbf{0 , 5 6}$ & $\mathbf{0 , 3 9}$ & $-1,00$ \\
\hline Árvakelés (8) & - & - & - & 0,00 & 0,00 & $\mathbf{0 , 1 3}$ & 0,00 & $-0,22$ & 0,00 \\
\hline
\end{tabular}

1.) rape, 2.) grassland, 3.) stubble, 4.) winter barley, 5.) winter wheat, 6.) sunflower, 7.) alfalfa, 8.) volunteer crop $\mathrm{S}=$ Spring; $\mathrm{Su}=$ Summer; $\mathrm{W}=$ Winter 
41. táblázat: A túzok élőhelypreferencia-értékei a Hevesi-síkon (2005-2008)

Table 41: Habitat selection values of Great Bustard in the Hevesi-plain (2005-2008)

\begin{tabular}{|l|c|c|c|c|c|c|c|c|c|}
\hline \multirow{2}{*}{$\begin{array}{c}\text { Élöhelytípus } \\
\text { Habitat }\end{array}$} & \multicolumn{3}{|c|}{$\mathbf{2 0 0 5 / 2 0 0 6}$} & \multicolumn{3}{c|}{$\mathbf{2 0 0 6 / 2 0 0 7}$} & \multicolumn{3}{c|}{$\mathbf{2 0 0 7 / 2 0 0 8}$} \\
\cline { 2 - 10 } & $\mathrm{Ta} / \mathrm{S}$ & $\mathrm{Ny} / \mathrm{Su}$ & $\mathrm{T} e / \mathrm{W}$ & $\mathrm{Ta} / \mathrm{S}$ & $\mathrm{Ny} / \mathrm{Su}$ & $\mathrm{T} e ́ / \mathrm{W}$ & $\mathrm{Ta} / \mathrm{S}$ & $\mathrm{Ny} / \mathrm{Su}$ & $\mathrm{T} e ́ / \mathrm{W}$ \\
\hline Lucerna (1) & $\mathbf{0 , 3 8}$ & $-1,00$ & $-1,00$ & $\mathbf{0 , 9 4}$ & $\mathbf{0 , 8 8}$ & $\mathbf{0 , 7 7}$ & $\mathbf{0 , 8 2}$ & $\mathbf{0 , 6 8}$ & $\mathbf{0 , 0 1}$ \\
\hline Gyep (2) & $\mathbf{0 , 0 1}$ & $\mathbf{0 , 3 2}$ & $-0,26$ & $-0,27$ & $-0,15$ & $-0,20$ & $\mathbf{0 , 2 5}$ & $\mathbf{0 , 1 0}$ & $-0,22$ \\
\hline Öszi gabona (3) & $\mathbf{0 , 1 7}$ & 0,00 & $-0,58$ & $-0,21$ & $\mathbf{1 , 0 0}$ & $-0,75$ & $-0,45$ & 0,00 & $-0,91$ \\
\hline Tarló (4) & $-1,00$ & $-1,00$ & 0,00 & 0,00 & $-0,83$ & $\mathbf{1 , 0 0}$ & 0,00 & $-1,00$ & 0,00 \\
\hline Repce (5) & $-0,18$ & 0,00 & $\mathbf{0 , 9 1}$ & $\mathbf{0 , 7 6}$ & 0,00 & $\mathbf{0 , 7 4}$ & $\mathbf{0 , 1 8}$ & 0,00 & $\mathbf{0 , 8 3}$ \\
\hline Parlag (6) & - & - & - & $-0,32$ & $\mathbf{0 , 3 4}$ & $-1,00$ & $-0,76$ & $\mathbf{0 , 2 1}$ & $-0,19$ \\
\hline Szántás (7) & - & - & - & $-0,39$ & $-1,00$ & $-1,00$ & $\mathbf{0 , 3 2}$ & 0,00 & $-1,00$ \\
\hline
\end{tabular}

1.) alfalfa, 2.) grassland, 3.) winter cereals, 4.), stubble, 5.) rape, 6.) follow, 7.) ploughed field $\mathrm{S}=$ Spring; $\mathrm{Su}=$ Summer; $\mathrm{W}=$ Winter

42. táblázat: A túzok élőhelypreferencia-értékei a Borsodi-Mezőségen (2005-2008)

Table 42: Habitat selection values of Great Bustard in the Borsodi-Mezőség (2005-2008)

\begin{tabular}{|l|c|c|c|c|c|c|c|c|c|}
\hline \multirow{2}{*}{$\begin{array}{c}\text { Élőhelytípus } \\
\text { Habitat }\end{array}$} & \multicolumn{3}{|c|}{$\mathbf{2 0 0 5 / 2 0 0 6}$} & \multicolumn{3}{c|}{$\mathbf{2 0 0 6 / 2 0 0 7}$} & \multicolumn{3}{c|}{ 2007/2008 } \\
\cline { 2 - 10 } & Ta/S & Ny/Su & Té/W & Ta/S & Ny/Su & Té/W & Ta/S & Ny/Su & Té/W \\
\hline Repce (4) & n.a & n.a & n.a & $\mathbf{0 , 9 0}$ & $-1,00$ & $\mathbf{0 , 8 1}$ & $-0,83$ & 0,00 & $\mathbf{0 , 8 3}$ \\
\hline Gyep (1) & n.a & n.a & n.a & $\mathbf{0 , 0 9}$ & $\mathbf{0 , 3 3}$ & $-1,00$ & $\mathbf{0 , 1 8}$ & $\mathbf{0 , 2 5}$ & 0,06 \\
\hline Lucerna (2) & n.a & n.a & n.a & $\mathbf{0 , 7 8}$ & $\mathbf{0 , 6 0}$ & $-1,00$ & $\mathbf{0 , 7 0}$ & 0,27 & $-1,00$ \\
\hline Öszi búza (3) & n.a & n.a & n.a & $-1,00$ & 0,00 & $-1,00$ & 0,00 & 0,00 & 0,00 \\
\hline Szántás (5) & n.a & n.a & n.a & - & - & - & 0,00 & $\mathbf{0 , 6 6}$ & $-0,40$ \\
\hline Tarló (6) & n.a & n.a & n.a & - & - & - & 0,00 & $-1,00$ & 0,00 \\
\hline
\end{tabular}

1.) grassland, 2.) alfalfa, 3.) winter wheat, 4.) rape. 5.) ploughed field, 6.) stubble $\mathrm{S}=$ Spring; $\mathrm{Su}=$ Summer; $\mathrm{W}=$ Winter; n.a.= no date

43. táblázat: A túzok élőhelypreferencia-értékei a Hortobágyon (2005-2008)

Table 43: Habitat selection values of Great Bustard in the Hortobágy (2005-2008)

\begin{tabular}{|l|c|c|c|c|c|c|c|c|c|}
\hline \multirow{2}{*}{$\begin{array}{c}\text { Élőhelytípus } \\
\text { Habitat }\end{array}$} & \multicolumn{3}{|c|}{$\mathbf{2 0 0 5 / 2 0 0 6}$} & \multicolumn{3}{c|}{$\mathbf{2 0 0 6 / 2 0 0 7}$} & \multicolumn{3}{c|}{ 2007/2008 } \\
\cline { 2 - 10 } & $\mathrm{Ta} / \mathrm{S}$ & $\mathrm{Ny} / \mathrm{Su}$ & $\mathrm{Té} / \mathrm{W}$ & $\mathrm{Ta} / \mathrm{S}$ & $\mathrm{Ny} / \mathrm{Su}$ & $\mathrm{T} e ́ / \mathrm{W}$ & $\mathrm{Ta} / \mathrm{S}$ & $\mathrm{Ny} / \mathrm{Su}$ & $\mathrm{T} e ́ / \mathrm{W}$ \\
\hline Gyep (1) & $\mathbf{0 , 2 6}$ & $-0,20$ & $-0,40$ & $-0,37$ & $-0,44$ & $-0,37$ & $-0,08$ & $-0,25$ & $-0,21$ \\
\hline Repce (2) & $\mathbf{0 , 6 3}$ & $\mathbf{0 , 7 6}$ & $\mathbf{0 , 9 5}$ & $\mathbf{0 , 7 8}$ & $-1,00$ & $\mathbf{0 , 8 1}$ & $\mathbf{0 , 6 5}$ & 0,00 & $\mathbf{0 , 8 2}$ \\
\hline Lucerna (3) & $\mathbf{0 , 3 1}$ & $\mathbf{0 , 3 7}$ & $-0,03$ & $\mathbf{0 , 8 5}$ & $\mathbf{0 , 6 2}$ & $\mathbf{0 , 8 5}$ & $\mathbf{0 , 7 0}$ & $\mathbf{0 , 6 8}$ & $-0,02$ \\
\hline Tarló (4) & 0,00 & 0,17 & 0,00 & $-1,00$ & $-0,60$ & $\mathbf{0 , 0 2}$ & $-1,00$ & $\mathbf{0 , 1 7}$ & 0,00 \\
\hline Öszi búza (5) & $-1,00$ & 0,00 & $\mathbf{0 , 3 0}$ & $\mathbf{0 , 2 0}$ & $\mathbf{1 , 0 0}$ & 0,30 & $-0,02$ & $\mathbf{1 , 0 0}$ & $-0,42$ \\
\hline Parlag (6) & - & - & - & $\mathbf{0 , 8 6}$ & $\mathbf{0 , 8 6}$ & $-1,00$ & - & - & - \\
\hline Árvakelés (7) & - & - & - & $\mathbf{0 , 5 9}$ & $-1,00$ & 0,00 & - & - & - \\
\hline
\end{tabular}

1.) grassland, 2.) rape, 3.) alfalfa, 4.) stubble, 5.) winter wheat, 6.) fallow, 7.) volunteer crop $\mathrm{S}=$ Spring; $\mathrm{Su}=$ Summer; $\mathrm{W}=$ Winter 
44. táblázat: A túzok élőhelypreferencia-értékei a Bihari-síkon (2005-2008)

Table 44: Habitat selection values of Great Bustard in the Bihari-plain (2005-2008)

\begin{tabular}{|l|c|c|c|c|c|c|c|c|c|}
\hline \multirow{2}{*}{$\begin{array}{c}\text { Élőhelytípus } \\
\text { Habitat }\end{array}$} & \multicolumn{3}{|c|}{$\mathbf{2 0 0 5 / 2 0 0 6}$} & \multicolumn{3}{c|}{$\mathbf{2 0 0 6 / 2 0 0 7}$} & \multicolumn{3}{c|}{ 2007/2008 } \\
\cline { 2 - 10 } & $\mathrm{Ta} / \mathrm{S}$ & $\mathrm{Ny} / \mathrm{Su}$ & $\mathrm{Té} / \mathrm{W}$ & $\mathrm{Ta} / \mathrm{S}$ & $\mathrm{Ny} / \mathrm{Su}$ & $\mathrm{Té} / \mathrm{W}$ & $\mathrm{Ta} / \mathrm{S}$ & $\mathrm{Ny} / \mathrm{Su}$ & $\mathrm{T} e ́ / \mathrm{W}$ \\
\hline Repce (1) & 0 & 0 & n.a. & $\mathbf{1 , 0 0}$ & 0,00 & $\mathbf{0 , 9 9}$ & $\mathbf{0 , 9 8}$ & 0,00 & $\mathbf{0 , 6 2}$ \\
\hline Lucerna (2) & $\mathbf{0 , 4 8}$ & $\mathbf{0 , 1 3}$ & n.a. & $\mathbf{0 , 3 2}$ & $\mathbf{0 , 6 0}$ & $\mathbf{0 , 1 0}$ & $\mathbf{0 , 4 3}$ & $\mathbf{0 , 8 3}$ & $-0,12$ \\
\hline Gyep (3) & $\mathbf{0 , 4 7}$ & $\mathbf{0 , 6 4}$ & n.a. & $\mathbf{0 , 2 8}$ & $\mathbf{0 , 2 9}$ & $\mathbf{0 , 1 2}$ & $\mathbf{0 , 1 9}$ & $\mathbf{0 , 1 5}$ & $\mathbf{0 , 2 3}$ \\
\hline Öszi gabona (4) & $-0,48$ & 0 & n.a. & $-1,00$ & 0 & $\mathbf{0 , 6 5}$ & $\mathbf{0 , 1 6}$ & $-0,45$ & $-0,56$ \\
\hline Mezsgye (5) & $-0,16$ & $-1,00$ & n.a. & $-1,00$ & $-1,00$ & $\mathbf{0 , 8 4}$ & - & - & - \\
\hline Kukorica (6) & $-0,18$ & $-1,00$ & n.a. & - & - & - & - & - & - \\
\hline Szántás (7) & - & - & - & $-1,00$ & $-1,00$ & $\mathbf{0 , 9 5}$ & $-1,00$ & 0,00 & $-1,00$ \\
\hline Ugar (8) & - & - & - & $\mathbf{0 , 6 4}$ & $\mathbf{0 , 8 4}$ & $-1,00$ & 0,39 & $-0,58$ & $-1,00$ \\
\hline Tarló (9) & - & - & - & - & - & - & 0,00 & $-0,59$ & $-1,00$ \\
\hline
\end{tabular}

1.) rape, 2.) alfalfa, 3.) grassland, 4.) winter cereals, 5.) balk, 6.) maize, 7.) ploughed field, 8.) set-aside, 9.) stubble $\mathrm{S}=$ Spring; $\mathrm{Su}=$ Summer; $\mathrm{W}=$ Winter; n.a. $=$ no data

45. táblázat: A túzok élőhelypreferencia-értékei Dévaványán (2005-2008)

Table 45: Habitat selection values Great Bustard in Dévaványa (2005-2008)

\begin{tabular}{|l|c|c|c|c|c|c|c|c|c|}
\hline \multirow{2}{*}{$\begin{array}{c}\text { Élöhelytípus } \\
\text { Habitat }\end{array}$} & \multicolumn{3}{|c|}{$\mathbf{2 0 0 5 / 2 0 0 6}$} & \multicolumn{3}{c|}{$\mathbf{2 0 0 6 / 2 0 0 7}$} & \multicolumn{3}{c|}{$\mathbf{2 0 0 7 / 2 0 0 8}$} \\
\cline { 2 - 10 } & $\mathrm{Ta} / \mathrm{S}$ & $\mathrm{Ny} / \mathrm{Su}$ & $\mathrm{T} / \mathrm{W}$ & $\mathrm{Ta} / \mathrm{S}$ & $\mathrm{Ny} / \mathrm{Su}$ & $\mathrm{T} e ́ / \mathrm{W}$ & $\mathrm{Ta} / \mathrm{S}$ & $\mathrm{Ny} / \mathrm{Su}$ & $\mathrm{T} / \mathrm{W}$ \\
\hline Repce (5) & $\mathbf{0 , 8 7}$ & $-1,00$ & $\mathbf{0 , 9 0}$ & $\mathbf{0 , 7 8}$ & 0,00 & $\mathbf{0 , 7 4}$ & $\mathbf{0 , 5 1}$ & 0,00 & $\mathbf{0 , 7 3}$ \\
\hline Lucerna (2) & $-1,00$ & $-1,00$ & $\mathbf{0 , 5 0}$ & $\mathbf{0 , 7 5}$ & $-1,00$ & $\mathbf{0 , 5 5}$ & $-0,17$ & $\mathbf{0 , 8 4}$ & $-0,13$ \\
\hline Öszi búza (4) & $-0,69$ & $-1,00$ & $-1,00$ & $-0,78$ & $-1,00$ & $-0,45$ & $-0,58$ & 0,00 & $\mathbf{1 , 0 0}$ \\
\hline Gyep (1) & $-0,07$ & $-1,00$ & $-0,41$ & $-0,62$ & $\mathbf{0 , 3 0}$ & $-0,62$ & $\mathbf{0 , 1 3}$ & $-0,13$ & 0,16 \\
\hline Napraforgó (3) & $-0,37$ & $\mathbf{0 , 5 6}$ & 0,00 & - & - & - & & & \\
\hline Szántás (6) & $\mathbf{0 , 6 3}$ & $\mathbf{0 , 2 3}$ & $-0,95$ & $-0,45$ & $-1,00$ & $-1,00$ & $\mathbf{0 , 0 5}$ & $-1,00$ & $-0,86$ \\
\hline Parlag (7) & - & - & - & $\mathbf{0 , 7 4}$ & $\mathbf{0 , 5 4}$ & 0,07 & $-0,07$ & $-0,06$ & $-0,10$ \\
\hline
\end{tabular}

1.) grassland, 2.) alfalfa, 3.) sunflower, 4.) winter wheat, 5.) rape, 6.) plowing, 7.) follow, 8.) volunteer crop $\mathrm{S}=$ Spring; $\mathrm{Su}=$ Summer; $\mathrm{W}=$ Winter

46. táblázat: A túzok élőhelypreferencia-értékei a Kis-Sárréten (2005-2008)

Table 46: Habitat selection values of Great Bustard in the Kis-Sárrét (2005-2008)

\begin{tabular}{|l|c|c|c|c|c|c|c|c|c|}
\hline \multirow{2}{*}{$\begin{array}{c}\text { Élöhelytípus } \\
\text { Habitat }\end{array}$} & \multicolumn{3}{|c|}{$\mathbf{2 0 0 5 / 2 0 0 6}$} & \multicolumn{3}{c|}{$\mathbf{2 0 0 6 / 2 0 0 7}$} & \multicolumn{3}{c|}{$\mathbf{2 0 0 7 / 2 0 0 8}$} \\
\cline { 2 - 10 } & $\mathrm{Ta} / \mathrm{S}$ & $\mathrm{Ny} / \mathrm{Su}$ & $\mathrm{Té} / \mathrm{W}$ & $\mathrm{Ta} / \mathrm{S}$ & $\mathrm{Ny} / \mathrm{Su}$ & $\mathrm{Té} / \mathrm{W}$ & $\mathrm{Ta} / \mathrm{S}$ & $\mathrm{Ny} / \mathrm{Su}$ & $\mathrm{T} / \mathrm{W}$ \\
\hline Gyep (1) & $\mathbf{0 , 3 2}$ & $\mathbf{0 , 3 3}$ & - & $\mathbf{0 , 3 3}$ & $\mathbf{0 , 3 3}$ & $\mathbf{0 , 2 1}$ & $\mathbf{0 , 2 6}$ & $-1,00$ & $-0,02$ \\
\hline Lucerna (2) & $-0,50$ & $-1,00$ & - & $-1,00$ & $-1,00$ & $\mathbf{0 , 2 9}$ & $-0,12$ & $\mathbf{0 , 8 3}$ & $\mathbf{0 , 8 8}$ \\
\hline Repce (3) & 0,00 & 0,00 & - & - & - & - & - & - & - \\
\hline Parlag (6) & - & - & - & $-1,00$ & $-1,00$ & $-1,00$ & $-1,00$ & $-1,00$ & $-1,00$ \\
\hline Tartló (7) & - & - & - & 0,00 & $-1,00$ & $-1,00$ & - & - & - \\
\hline Szántás (4) & - & - & - & - & - & - & 0,00 & $-1,00$ & $-1,00$ \\
\hline
\end{tabular}

1.) grassland, 2.) alfalfa, 3.) rape, 4.) plowing, 5.) set-aside, 6.) fallow, 7.) stubble, 8,) winter wheat $\mathrm{S}=$ Spring; $\mathrm{Su}=$ Summer; $\mathrm{W}=$ Winter 


\section{7. táblázat: A túzok pozitív élőhelypreferenciái évszakonként Magyarországon}

Table 47: Seasonal positive habitat preference-values in Hungary

\begin{tabular}{|c|c|c|c|c|}
\hline Terület- Area & Év - Year & Tavasz - Spring & Nyár - Summer & Tél - Winter \\
\hline \multirow{3}{*}{$\begin{array}{l}\text { Mosoni-sík } \\
\text { Mosoni-plain }\end{array}$} & $2005-2006$ & ugar $(0,84)$ & ugar $(0,83)$ & repce $(0,86)$ \\
\hline & 2006-2007 & $\begin{array}{l}\text { ugar }(0,77), \text { gyep } \\
(0,62), \text { repce }(0,52),\end{array}$ & $\begin{array}{l}\text { ugar }(0,42), \text { tarló } \\
(0,26), \text { gyep }(0,22)\end{array}$ & $\begin{array}{l}\text { repce }(0,77) \text {, tarló } \\
(0,11)\end{array}$ \\
\hline & 2007-2008 & $\begin{array}{l}\text { árvakelés }(0,86) \text {, ugar } \\
(0,78)\end{array}$ & ugar $(0,77)$ & $\begin{array}{l}\text { repce }(0,77) \text {, lucerna } \\
(0,09)\end{array}$ \\
\hline \multirow{3}{*}{ Kiskunság } & $2005-2006$ & $\begin{array}{l}\text { repce }(0,97) \text {, parlag } \\
(0,47), \text { lucerna }(0,27)\end{array}$ & $\begin{array}{l}\text { öszi búza }(1,00) \text {, } \\
\text { lucerna }(0,69), \text { parlag } \\
(0,51) \text {, szántás }(0,48) \\
\end{array}$ & $\begin{array}{l}\text { repce }(0,91) \text {, szántás } \\
(0,34)\end{array}$ \\
\hline & 2006-2007 & $\begin{array}{l}\text { kukorica }(1,00) \text {, repce } \\
(0,83) \text {, lucerna }(0,40), \\
\text { tarló }(0,12) \text {, parlag } \\
(0,06)\end{array}$ & $\begin{array}{l}\text { tarló }(0,55), \text { lucerna } \\
(0,51), \text { szántás }(0,42)\end{array}$ & $\begin{array}{l}\text { repce }(0,85) \text {, lucerna } \\
(0,28)\end{array}$ \\
\hline & 2007-2008 & $\begin{array}{l}\text { repce }(0,45) \text {, öszi búza } \\
(0,43) \text {, lucerna }(0,41), \\
\text { parlag }(0,06)\end{array}$ & $\begin{array}{l}\text { öszi búza }(1,00) \text {, tarló } \\
(0,71) \text {, lucerna }(0,39) \text {, } \\
\text { parlag }(0,13)\end{array}$ & $\begin{array}{l}\text { repce }(0,90), \text { parlag } \\
(0,21)\end{array}$ \\
\hline \multirow{3}{*}{$\begin{array}{l}\text { Solti-sík } \\
\text { Solti-plain }\end{array}$} & 2005-2006 & $\begin{array}{l}\text { napraforgó }(1,00) \text {, öszi } \\
\text { árpa }(0,65) \text {, őszi búza } \\
(0,17), \text { gyep }(0,10)\end{array}$ & $\begin{array}{l}\text { tarló }(1,00), \text { gyep } \\
(0,24)\end{array}$ & repce $(0,87)$ \\
\hline & 2006-2007 & $\begin{array}{l}\text { tarló }(1,00) \text {, lucerna } \\
(0,53)\end{array}$ & tarló $(0,29)$ & $\begin{array}{l}\text { repce }(0,75) \text {, gyep } \\
(0,34) \text {, árvakelés } \\
(0,13)\end{array}$ \\
\hline & 2007-2008 & $\begin{array}{l}\text { lucerna }(0,56) \text {, gyep } \\
(0,31) \text {, öszi búza } \\
(0,02)\end{array}$ & $\begin{array}{l}\text { tarló }(0,42) \text {, lucerna } \\
(0,39) \text {, gyep }(0,07)\end{array}$ & repce $(0,92)$ \\
\hline \multirow{3}{*}{$\begin{array}{l}\text { Hevesi-sík } \\
\text { Hevesi-plain }\end{array}$} & $2005-2006$ & $\begin{array}{l}\text { lucerna }(0,38) \text {, öszi } \\
\text { gabona }(0,17) \text {, gyep } \\
(0,01)\end{array}$ & gyep $(0,32)$ & repce $(0,91)$ \\
\hline & 2006-2007 & $\begin{array}{l}\text { lucerna }(0,94) \text {, repce } \\
(0,76)\end{array}$ & $\begin{array}{l}\text { öszi gabona }(1,00) \text {, } \\
\text { lucerna }(0,88) \text {, parlag } \\
(0,34)\end{array}$ & $\begin{array}{l}\text { tarló }(1,00), \text { lucerna } \\
(0,77), \text { repce }(0,74)\end{array}$ \\
\hline & $2007-2008$ & $\begin{array}{l}\text { lucerna }(0,82) \text {, szántás } \\
(0,32) \text {, gyep }(0,25), \\
\text { repce }(0,18)\end{array}$ & $\begin{array}{l}\text { lucerna }(0,68), \text { parlag } \\
(0,21) \text {, gyep }(0,10)\end{array}$ & $\begin{array}{l}\text { repce }(0,83) \text {, lucerna } \\
(0,01)\end{array}$ \\
\hline \multirow{3}{*}{$\begin{array}{l}\text { Borsodi- } \\
\text { Mezőség }\end{array}$} & $2005-2006$ & n. a. & n.a. & n. a. \\
\hline & $2006-2007$ & $\begin{array}{l}\text { repce }(0,90) \text {, lucerna } \\
(0,78), \text { gyep }(0,09)\end{array}$ & $\begin{array}{l}\text { lucerna }(0,60) \text {, gyep } \\
(0,33)\end{array}$ & repce $(0,81)$ \\
\hline & $2007-2008$ & $\begin{array}{l}\text { lucerna }(0,70) \text {, gyep } \\
(0,18)\end{array}$ & $\begin{array}{l}\text { szántás }(0,66) \text {, gyep } \\
(0,25)\end{array}$ & repce $(0,83)$ \\
\hline \multirow{3}{*}{ Hortobágy } & $2005-2006$ & $\begin{array}{l}\text { repce }(0,63) \text {, lucerna } \\
(0,31) \text {, gyep }(0,26)\end{array}$ & $\begin{array}{l}\text { repce }(0,76) \text {, lucerna } \\
(0,37)\end{array}$ & $\begin{array}{l}\text { repce }(0,95) \text {, gabona } \\
(0,30)\end{array}$ \\
\hline & $2006-2007$ & $\begin{array}{l}\text { parlag }(0,86), \text { lucerna } \\
(0,85), \text { repce }(0,78), \\
\text { árvakelés }(0,59), \text { őszi } \\
\text { búza }(0,20)\end{array}$ & $\begin{array}{l}\text { őszi búza }(1,00) \text {, } \\
\text { parlag }(0,86), \text { lucerna } \\
(0,62)\end{array}$ & $\begin{array}{l}\text { lucerna }(0,85) \text {, repce } \\
(0,81) \text {, tarló }(0,02)\end{array}$ \\
\hline & $2007-2008$ & $\begin{array}{l}\text { lucerna }(0,70) \text {, repce } \\
(0,65)\end{array}$ & $\begin{array}{l}\text { öszi búza }(1,00) \text {, } \\
\text { lucerna }(0,68) \text {, tarló } \\
(0,17)\end{array}$ & repce $(0,82$ \\
\hline \multirow{3}{*}{$\begin{array}{l}\text { Bihari-sík } \\
\text { Bihari-plain }\end{array}$} & $2005-2006$ & $\begin{array}{l}\text { lucerna }(0,48) \text {, gyep } \\
(0,47)\end{array}$ & $\begin{array}{l}\text { gyep }(0,64), \text { lucerna } \\
(0,13)\end{array}$ & n. a. \\
\hline & $2006-2007$ & $\begin{array}{l}\text { repce }(1,00) \text {, ugar } \\
(0,64) \text {, lucerna }(0,32) \text {, } \\
\text { gyep }(0,28)\end{array}$ & $\begin{array}{l}\text { ugar }(0,84) \text {, lucerna } \\
(0,60) \text {, gyep }(0,29)\end{array}$ & $\begin{array}{l}\text { repce }(0,99) \text {, szántás } \\
(0,95) \text {, mezsgye } \\
(0,84) \text {, öszi gabona } \\
(0,65) \text {, gyep }(0,12), \\
\text { lucerna }(0,10)\end{array}$ \\
\hline & $2007-2008$ & $\begin{array}{l}\text { repce }(0,98) \text {, lucerna } \\
(0,43) \text {, gyep }(0,19), \\
\text { gabona }(0,16)\end{array}$ & $\begin{array}{l}\text { lucerna }(0,83) \text {, gyep } \\
(0,15)\end{array}$ & $\begin{array}{l}\text { repce }(0,62) \text {, gyep } \\
(0,23)\end{array}$ \\
\hline
\end{tabular}




\section{7. táblázat (folyt): A túzok pozitív élőhelypreferenciái évszakonként Magyarországon}

Table 47 (cont): Seasonal positive habitat preference-values in Hungary

\begin{tabular}{|l|l|l|l|l|}
\hline Terület- Area & Év - Year & \multicolumn{1}{|c|}{ Tavasz - Spring } & \multicolumn{1}{|c|}{ Nyár - Summer } & \multicolumn{1}{|c|}{ Tél - Winter } \\
\hline \multirow{5}{*}{ Dévaványa } & $2005-2006$ & $\begin{array}{l}\text { repce }(0,87), \text { szántás } \\
(0,63)\end{array}$ & $\begin{array}{l}\text { napraforgó }(0,56), \\
\text { szántás }(0,23)\end{array}$ & $\begin{array}{l}\text { repce }(0,90), \text { lucerna } \\
(0,50)\end{array}$ \\
\cline { 2 - 5 } & $2006-2007$ & $\begin{array}{l}\text { repce }(0,78), \text { lucerna } \\
(0,75), \text { parlag }(0,74)\end{array}$ & $\begin{array}{l}\text { parlag }(0,54), \text { gyep } \\
(0,30)\end{array}$ & $\begin{array}{l}\text { repce }(0,74), \text { lucerna } \\
(0,55)\end{array}$ \\
\cline { 2 - 6 } & $2007-2008$ & $\begin{array}{l}\text { repce }(0,51), \text { gyep } \\
(0,13), \text { szántás }(0,05)\end{array}$ & lucerna $(0,84)$ & $\begin{array}{l}\text { ószi búza }(1,00), \text { repce } \\
(0,73)\end{array}$ \\
\hline \multirow{4}{*}{ Kis-Sárrét } & $2005-2006$ & gyep $(0,32)$ & gyep $(0,33)$ & n. a. \\
\cline { 2 - 6 } & $2006-2007$ & gyep $(0,33)$ & gyep $(0,33)$ & $\begin{array}{l}\text { lucerna }(0,29), \text { gyep } \\
(0,21)\end{array}$ \\
\cline { 2 - 6 } & $2007-2008$ & gyep $(0,26)$ & lucerna $(0,83)$ & lucerna $(0,88)$ \\
\hline
\end{tabular}

Általánosságban elmondható, hogy a növényzet magassága elsősorban a preferencia oka, ugyanakkor az élőhely növényi és állati táplálékkínálata is erős motivációs tényező volt.

A tavaszi, dürgési időszakban a növénymagasság kiemelkedően fontos, mert az ú.n. labdadürgés (balloon display) lényege, hogy a tradicionális dürgőhelyeken dürgő kakasok vizuális szignálja (messzelátszó fehér gömb) a lekekre vonzza a tyúkokat. Ezért ebben az időszakban az alacsony növényzet (gyep, őszi gabona, lucerna, repce), az ugar, a parlag, vagy éppen a növénymentes szántás (esetleg magágy) a preferált. A fészkelés során a növényzetnek már megjelenik a fészekrejtő funkciója, ekkor a választásban a jobb takarást - de azért kilátást is - biztosító növények vannak elönyben. Az aktuális fejlettséget meghatározó csapadék mértéke határozza meg, hogy inkább a gyepeket és a gabonákat (csapadékhiány), vagy a lucernát (csapadékos év) részesítik előnybe (FODOR, 1985; FARAGÓ, 1987; 1990a). Abban az esetben, ha a megkésett első, vagy a sarjúfészkelés idején a tavaszi vetésü növények magassága a rejtőzködés/takarás kritériumait kielégíti, abban az esetben, azokban is megfigyelhetők, sőt költhetnek is ott (FARAGÓ, 1987; 1990a).

A nyári, csibevezetési időszakban, illetve a kakascsapatok kóborlása során már a táplálékkínálat az elsődleges élőhelyválasztási kritérium, ugyanakkor a takarásigény némileg háttérbe szorul. Mivel erre az időre már a repcék és a gabonák betakarítása megtörténik (a kései betakarítású táblákat viszont továbbra is preferálják), a tarlók, a gyepek, a lucernák, az ugarok és parlagok, a tárcsázott, vagy szántott táblák a választott tartózkodási helyeik.

Télen a jelentősen leszükült élőhelykínálatból történő választás a fagyhatásnak és a hótakaró vastagságának a függvénye. A fagyokkal a lucerna levelei leperegnek, így akkor azt elkerülik. A hóborítás az őszi gabonák és gyepek választását is visszaveti. Mindenkor kiemelt viszont a repce preferálása, hiszen annak táplálékkínálata és védelme minden téli túzokszükségletet kielégít. Évszázados tapasztalat, hogy a túzokcsapat (zavarás hiányában) akár át is telel egy repcetáblán. Elmondottakat valamennyi vizsgálati területünköt igazoltnak találtuk (47. táblázat). 


\section{MEGVITATÁS}

Az eredmények azt mutatták, hogy a túzokkíméleti területek teóriája és gyakorlata igazolta kialakításuk létjogosultságát. Különösen az extenzíven (beleértve parlag területeket is) kezelt dürgőhely és környéke rendelkezik jelentős túzok-megtartó erővel. Ezt a dürgési és fészkelési időben fennálló nyugalom, a diverz élőhely-szerkezet, a kedvező mikroklimatikus és táplálékviszonyok biztosítják. A parlag és ugar (set-aside) területek nemcsak a csibék számára oly nélkülözhetetlen állati eredetü - föként ízeltlábú - táplálék mennyiségét, de minőségét, azaz diverzitását is biztosítják. A kíméleti területeken foganatosított, csaknem teljesen kemikáliától mentes gazdálkodás pedig megakadályozza a közvetlen és közvetett növényvédőszer kontaminációt. Végül és nem utolsó sorban e módszerrel kiküszöbölhetők azok, a mezőgazdaság gépesítettségéből eredő káros technológiai hatások (főként a kaszálási veszteségek), amelyek a túzok számára a legnagyobb veszélyt jelentik. Ezek a módszerek hasonló állapotot teremtenek, mint amilyen a magyar mezőgazdaság extenzív időszakában, egyúttal a magyar apróvadállomány ,aranykorában”, a 19-20. század fordulóján létezett (FARAGÓ, 1997b). A területek feltétlen hatását, továbbá az élőhelyfejlesztések során alkalmazott élőhelyek minőségét (,jóságát”) kétséget kizárólag igazolták a korábbi spanyol (AlONSO \& ALONSO, 1990) és a bemutatatt magyar élöhelypreferencia vizsgálatok.

$\mathrm{Az}$ ugarok/parlagok valamint tarlók jelentőségét bizonyítják spanyolországi vizsgálatok is (AlONSO \& ALONSO, 1990; LANE et al., 2001; LÓPEZ-JAMAR et al., 2011), különösen azokon a területeken, ahol infrastruktúrafejlesztések valósultak meg, illetve a tájhasználat változott. Az említett élőhelyek mellett a lucerna pozitív preferenciáját mutatta ki ALONSO \& ALONSO (1990), ami megegyezik saját vizsgálataink eredményével. Általában megfogalmazható, hogy mind térbeli, mind időszakos változékonyság megfigyelhető az élőhely preferenciában (MARTíN et al. 2012). A gabonatáblák fontossága elsősorban a fészkelőhelyek biztosításában van (lásd MAGAÑA et al. 2010), de emellett az utánuk keletkező tarlót, illetve ugart preferálja a túzok az év nagy részében.

Egyértelműen elkerülik a túzokok a települések, forgalmas utak (általában az erős emberi hatás alatti területek) környékét és a horizontálisan nem belátható élőhelyeket (AlONSO \& AlONSO, 1990; LANE et al., 2001; OsBORNE et al. 2001).

Minden spanyol szerző megemlíti a túzok területhüségét, mind a lekeket, mind a fészkelö, mind bizonyos telelőterületeket illetően (AlONSO \& AlONSO, 1990; AlONSO et al., 2000; LANE et al., 2001; OSBORNE et al., 2001), amit saját eredményeink magyar viszonyok között is megerösítettek. E területhüségnek a Kárpát-medencében azért is van kiemelt jelentősége, mert e vidéken a túzoknak csak extrém időjárási körülmények mellett figyelhető meg téli migrációja (FARAGó, 1990b), szemben a spanyol populációk részleges, rövid/középtávú elmozdulásával (AlONso et al. 1995, AlONSO et al. 2000, Alonso et al. 2001; PALACIN et al., 2012), így a lekek környékén létesített túzok kíméleti területek védelmi hatékonysága nagyobb.

Zárókonklúzióként megállapíthatjuk, hogy a túzokkíméleti területek élőhelystruktúrájának kialakításakor az előzetes, tapasztalati alapon meghatározott elöírások beváltották az elképzeléseket. Ahol azokat következetesen megvalósították, ott eredményes volt a területek elfoglalása, illetve az élőhelyek használata/választása. Ahol a kulcs élőhelytípusok (pl. repce, öszi gabonák) telepítése, fenntartása elmaradt, ott a terület elhagyása is bekövetkezett. Fontos ugyanakkor az élettér bizonyos fokú diverzitása, mert a térben és időben megjelenő kíméletes mintázat-változás előnyösebb, mint pl. a teljes ősgyep egyhangúság. 


\section{KÖSZÖNETNYILVÁNÍTÁS}

Köszönjük a Project felméréseiben részt vett munkatársak pontos munkáját, adatszolgáltatását. Nélkülük ez az elemzés nem születhetett volna meg. A részprojektek munkatársai voltak: SPAKOvSZKY PÉTER, LóRÁNT MikLós, NÉMETH ÁKOS, FATÉr IMRE, Ferencz Attila, Tóth lászló, Borbáth Péter, Bodnár Mihály, Mezei János, Seres NÁndor, Konyhás SÁndor, Motkó Béla, Horváth Gábor, SzÉll ANTAl, Szelényi BALÁZS, TÓTH IMRE.

\section{MELLÉKLET}

\begin{tabular}{|l|c|c|}
\hline Terület - Area & $\begin{array}{c}\text { LIFE Mintaterület mérete } \\
\text { Size of plots of LIFE Project } \\
\left(\mathrm{km}^{2}\right)\end{array}$ & $\begin{array}{c}\text { Monitoring terület mérete } \\
\text { Size of monitoring area } \\
\left(\mathrm{km}^{2}\right)\end{array}$ \\
\hline $\begin{array}{l}\text { Mosoni-sík } \\
\text { Mosoni-plain }\end{array}$ & 112,18 & 112,18 \\
\hline Kiskunság & 380,20 & 56,54 \\
\hline $\begin{array}{l}\text { Solti-sík } \\
\text { Solti-plain }\end{array}$ & 178,95 & 44,15 \\
\hline $\begin{array}{l}\text { Hevesi-sík } \\
\text { Hevesi-plain }\end{array}$ & 341,38 & 54,21 \\
\hline Borsodi-Mezőség & 240,16 & 34,90 \\
\hline Hortobágy & 282,81 & 51,13 \\
\hline $\begin{array}{l}\text { Bihari-sík } \\
\text { Bihari-plain }\end{array}$ & 730,33 & 68,00 \\
\hline Dévaványa & 122,54 & 48,03 \\
\hline Kis-Sárrét & 24,28 & 24,28 \\
\hline
\end{tabular}

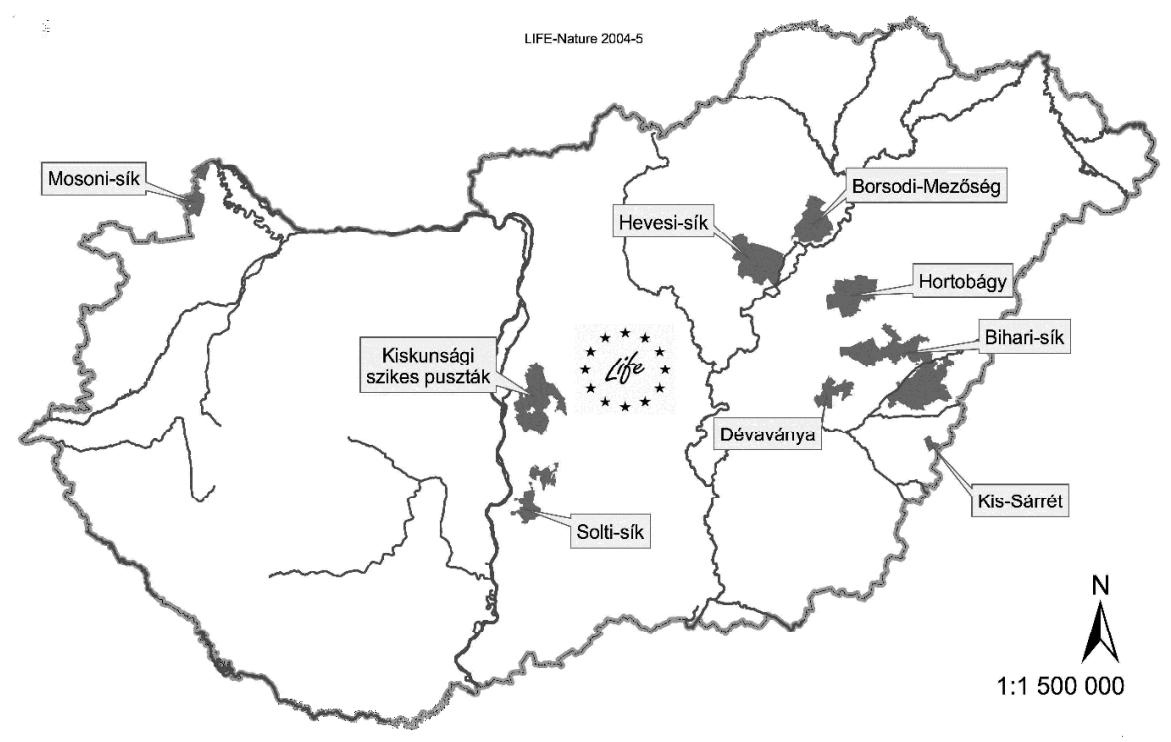

A LIFE Túzokvédelmi Program monitoring területei

The sites of the Hungarian OTIS-LIFE Project 


\section{IRODALOMJEGYZÉK}

Alonso, J. C. \& Alonso, J. A. (Eds.) (1990): Parametros demograficos, seleccion de habitat y distribution de la avutarda (Otis tarda) en tres regiones Españolas. [Demographic parameters, habitat selection and distribution of Great Bustards (Otis tarda) in three Spanish regions.] - ICONA - F.E.P.M.A. Madrid, Spain. 123.

Alonso, J. C., Alonso, J. A., Martín, E. \& Morales, M. (1995): Range and patterns of great bustard movements at Villafafíla, NW Spain. Ardeola 42(1): 69-76.

Alonso, J. C., Morales, M. B. \& Alonso, J. A. (2000): Partial migration, and lek and nesting area fidelity in female great bustards. The Condor 102: 127-136. http://dx.doi.org/10.2307/1370413

Alonso, J. C., Martín, C. A., Alonso, J. A., Morales, M. B. \& Lane, S. J. (2001): Seasonal Movement of Male Great Bustards in Central Spain. Journal of Field Ornithology 72(4): 504-508. http://dx.doi.org/10.1648/0273-8570-72.4.504

FARAGÓ S. (1987): A növényzet szerepe a túzok (Otis t. tarda LiNNÉ, 1758) elterjedésében és költésbiológiájában Magyarországon. Erdészeti és Faipari Tudományos Közlemények 1986 (1): 177-213.

FARAGÓ S. (1989): A mezőgazdaság hatása a túzok (Otis tarda L.) állományra Magyarországon [Effect of agriculture on Great Bustard (Otis tarda L.) population in Hungary]. Nimród Fórum 1989. október: 12-30.

FARAGÓ S. (1990a): A túzok Magyarországon (The Great Bustard in Hungary). Venatus, Budapest, 78 p.

FARAGÓ S. (1990b). A kemény telek hatása Magyarország túzok (Otis tarda L.) állományára. Állattani Közlemények 76: 51-62.

FARAGÓ S. (1992): A túzok (Otis tarda L.)-állomány fenntartásának ökológiai alapjai Magyarországon [Ecologigal basis of maintenance of Great Bustard (Otis tarda) population in Hungary]. Kandidátusi értekezés tézisei. (Thesis in the Hungarian Academy of Sciences) Sopron. Kandidátusi értekezés, $131+215$ p.

FARAGÓ S. (1993): Vadon élő állatfajok fennmaradásának lehetősége mezőgazdasági környezetben Magyarországon (Possibilitiy of remaining of wild animals in agricultural environment in Hungary). WWF-füzetek 4: $24 \mathrm{p}$.

FARAGÓ S. (1997a): Élőhelyfejlesztés az apróvad-gazdálkodásban. A fenntartható apróvadgazdálkodás környezeti alapjai (Habitat improvement in the small game managemt. Environmental basis of the sustainable small game management). Mezőgazda Kiadó, Budapest, $356 \mathrm{p}$.

FARAGÓ S. (1997): Changes in small game habitat structure in Hungary in the last 100 years. Magyar Apróvad Közlemények 1: 89-106.

FARAGÓ S. (1998): Habitat selection by Grey Partridge (Perdix perdix) in the area of the LAJTA Project (Western Hungary). Gibier Faune Sauvage - Game and Wildlife 15 (4): 481-490.

FARAGÓ S. \& KALMÁR S. (2006): A túzok védelme Magyarországon. LIFE Nature Project 2005. évi monitoring jelentése. Magyar Apróvad Közlemények Supplement, 2006: 1-142.

FARAGÓ S. \& KALMÁR S. (2007): A túzok védelme Magyarországon. LIFE Nature Project 2006. évi monitoring jelentése. Magyar Apróvad Közlemények Supplement, 2007: 1-184.

FODOR T. (1985): Adatok a túzok szaporodásbiológiájához. A vadgazdálkodás fejlesztése 16. Szárnyasvadtenyésztés: 103-113.

KALMÁr S. \& FARAGÓ S. (2008): A túzok védelme Magyarországon. LIFE Nature Project 2007-2008. évi monitoring jelentése. Magyar Apróvad Közlemények Supplement, 2008, 282 pp.

IVLEV, V. S. (1961): Experimental ecology of the feeding of fishes. Yale University Press, New Haven. 
LANE, S. J., Alonso, J. C. \& MARTín, C. A. (2001): Habitat preferences of great bustard Otis tarda flocks in the arable steppes of central Spain: are potentially suitable areas unoccupied? Journal of Applied Ecology 38: 193-203. http://dx.doi.org/10.1046/j.1365-2664.2001.00577.x

LÓPEZ-JAMAR, J. L., CASAS, F. DÍAZ, M. \& MORALES, M. B. (2011): Local differences in habitat selection by Great Bustard Otis tarda in changing agricultural landscapes: implications for farmland bird conservation. Bird Conservation International 21(3): 328-341.

martín, B., Alonso, J. C., Martín, C. A., Palacín, C., Magaña, M. \& Alonso, J. (2012): Influence of spatial heterogeneity and temporal variability in habitat selection. A case study on a great bustard metapopulation. Ecological Modelling 228: 39-48. http://dx.doi.org/10.1016/j.ecolmodel.2011.12.024

Magaña, M., Alonso, J. C., Martín, C. A., Bautista, L. M. \& Martín, B. (2010): Nest-site selection by Great Bustards Otis tarda suggests a trade-off between concealment and visibility. Ibis 152(1): 77-89. http://dx.doi.org/10.1111/j.1474-919X.2009.00976.x

Osborne, P. E., AlOnso, J. C. \& BRyAnT, R. G. (2001): Modelling landscape-scale habitat use using GIS and remote sensing: a case study with great bustards. Journal of Applied Ecology 38: 458-471. http://dx.doi.org/10.1046/j.1365-2664.2001.00604.x

Palacin, C., Alonso, J. C., Martín, C. A. \& Alonso, J. A. (2012): The importance of traditional farmland areas for steppe birds a case study of migrant female Great Bustards Otis tarda in Spain. Ibis 154(1): 85-95. http://dx.doi.org/10.1111/j.1474-919X.2011.01183.x 